Fall 1936

\title{
1936 Cedrus Yearbook
}

\section{Cedarville College}

Follow this and additional works at: https://digitalcommons.cedarville.edu/yearbooks

Part of the Higher Education Commons, Organizational Communication Commons, and the Public Relations and Advertising Commons

\section{Recommended Citation}

Cedarville College, "1936 Cedrus Yearbook" (1936). Yearbooks. 73.

https://digitalcommons.cedarville.edu/yearbooks/73

This Book is brought to you for free and open access by DigitalCommons@Cedarville, a service of the Centennial Library. It has been accepted for inclusion in Yearbooks by an authorized administrator of DigitalCommons@Cedarville. For more information, please contact digitalcommons@cedarville.edu. 


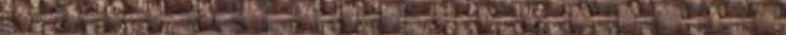
2.

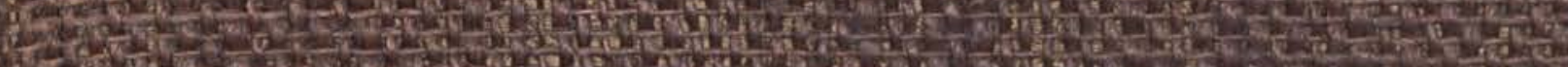

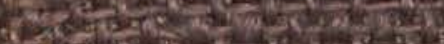

4.

(1.
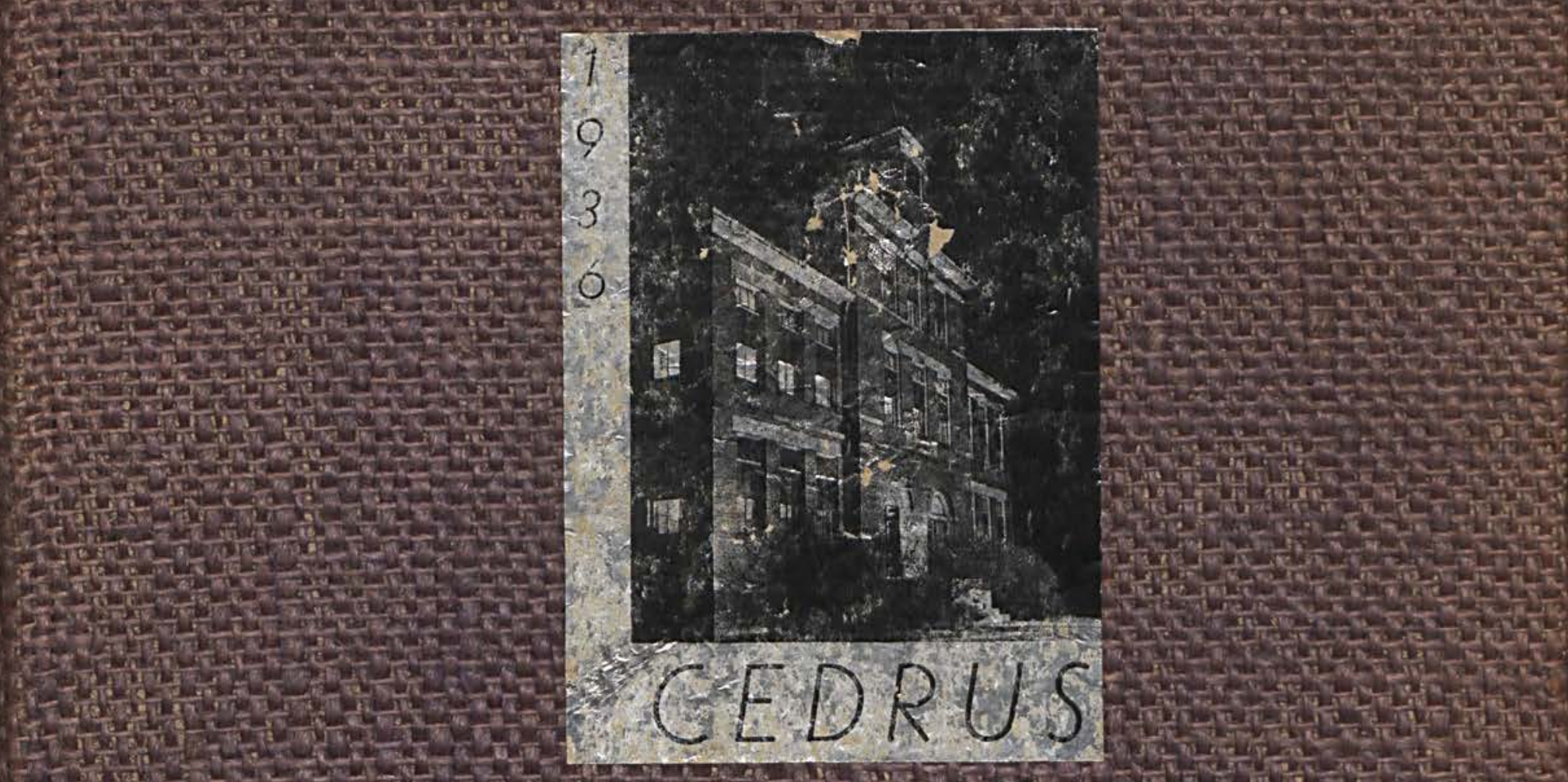

4. (1)

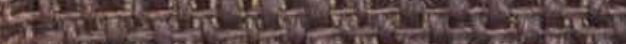

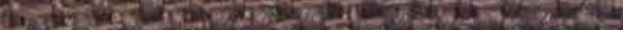

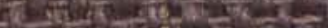

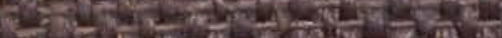

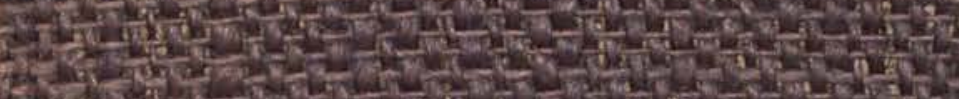

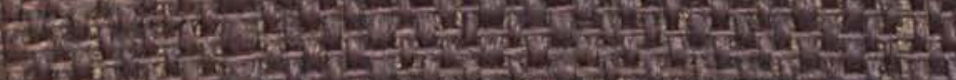

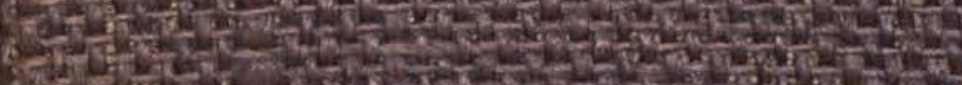
2.

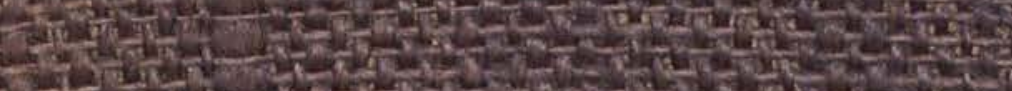

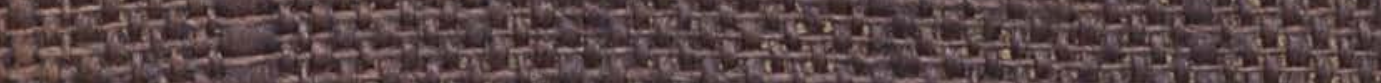
c.

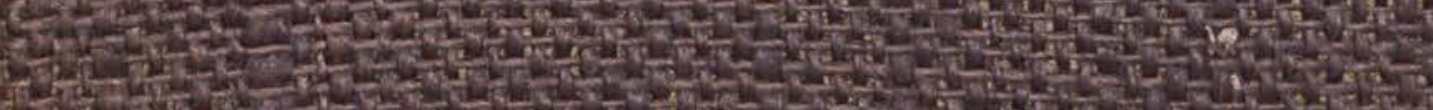

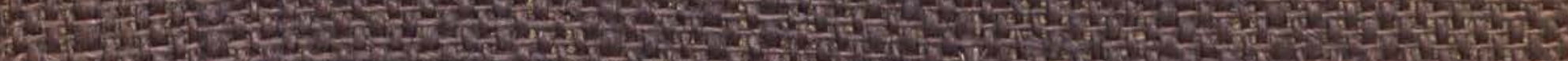

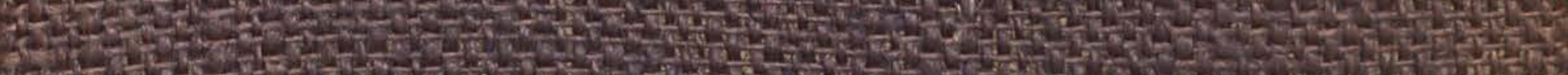

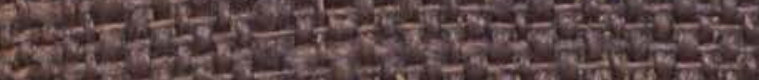

T. 2-2.

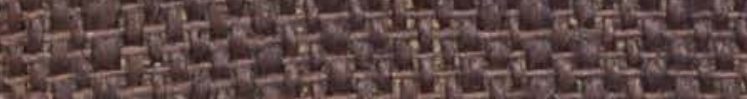

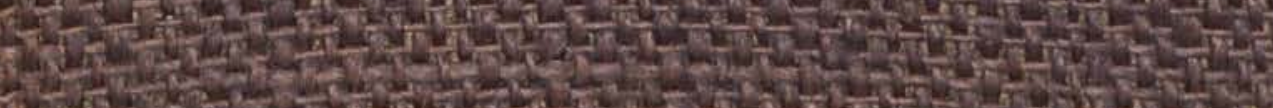

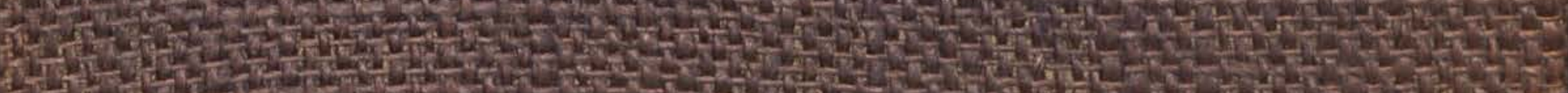

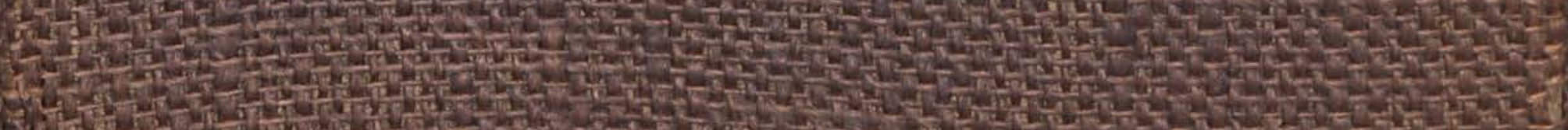

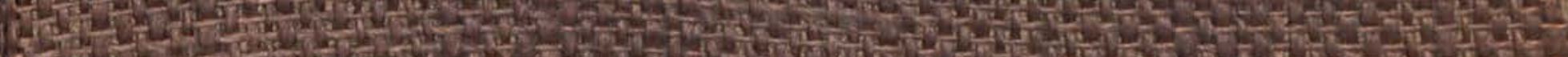

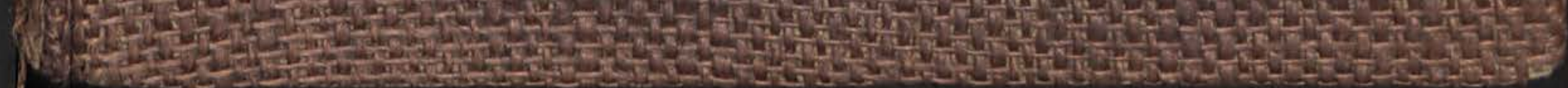



4 


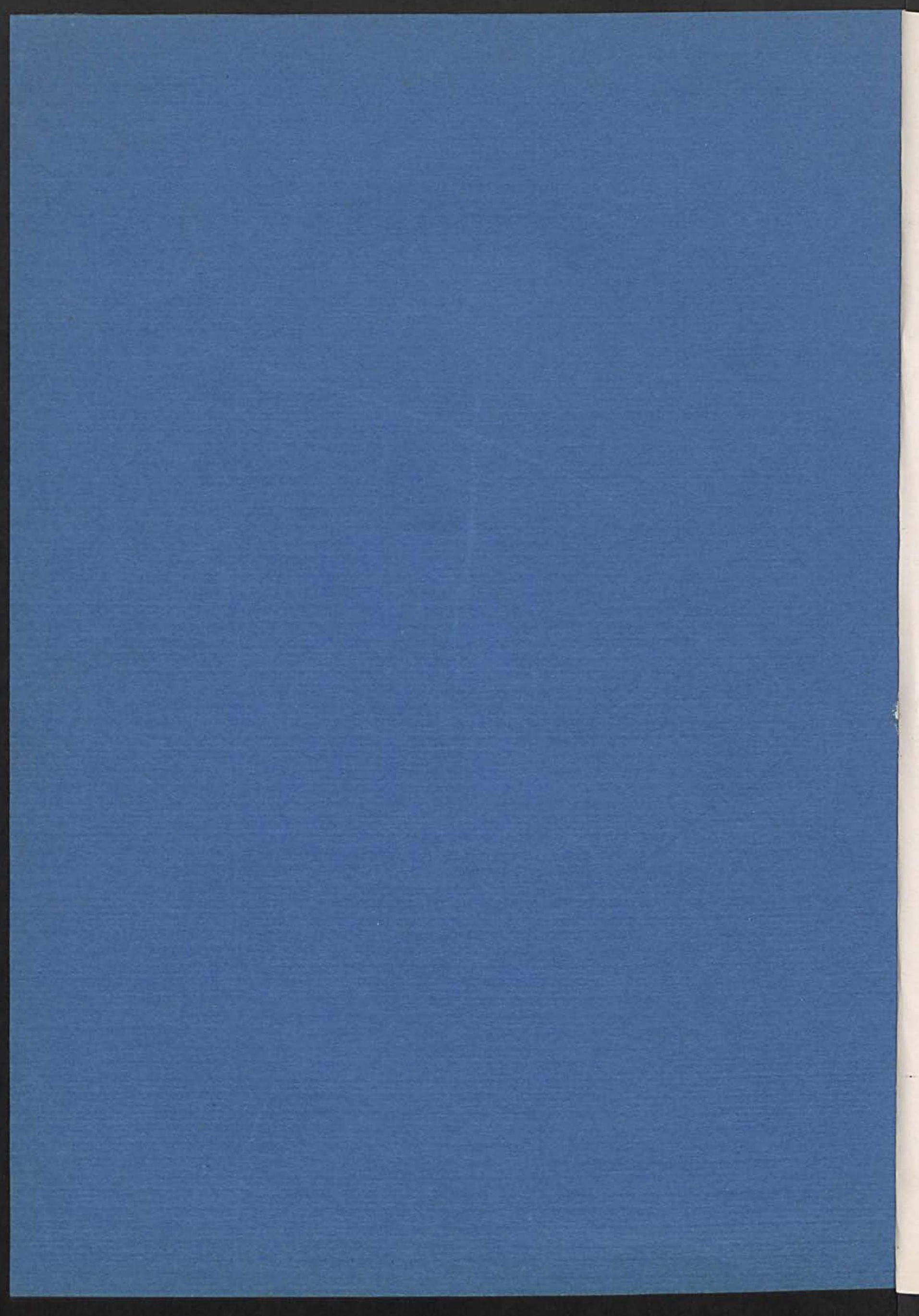




\section{$\star \star \star$ \\ T H E \\ $\begin{array}{llll}1 & 9 & 3 & 6\end{array}$ CEDRUS}

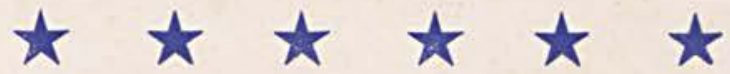

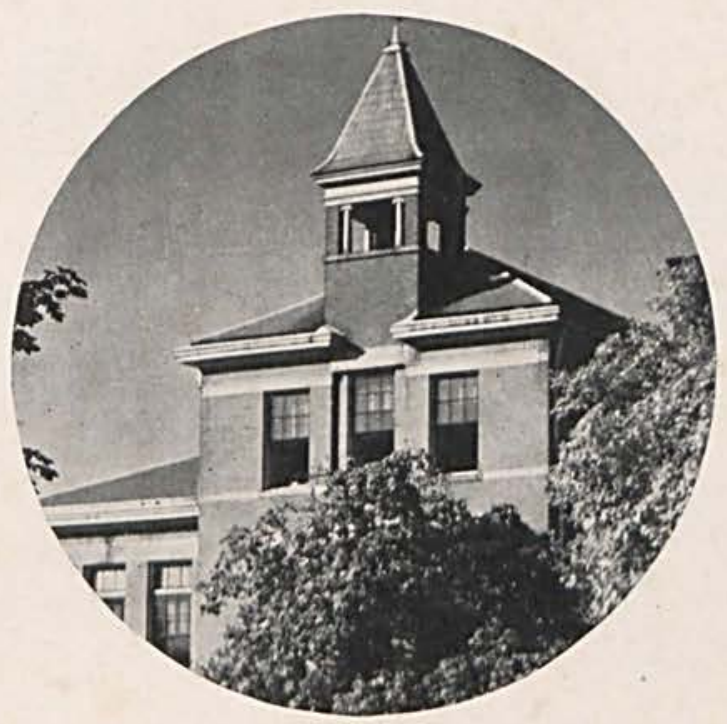

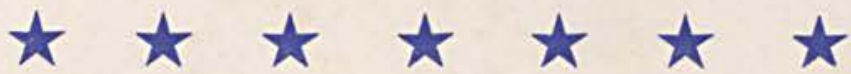

CEDARVILLE COLLEGE CEDARVILLE, OHIO

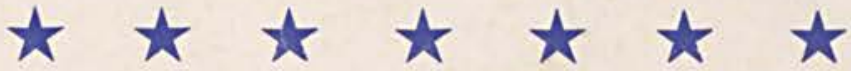




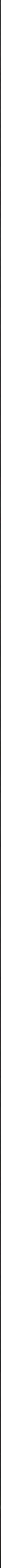




\section{PREF A C E}

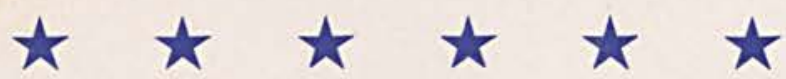

We present to you this 1936

Cedrus with which we have endeavored to give the activities and spirit of the colllege this past year.
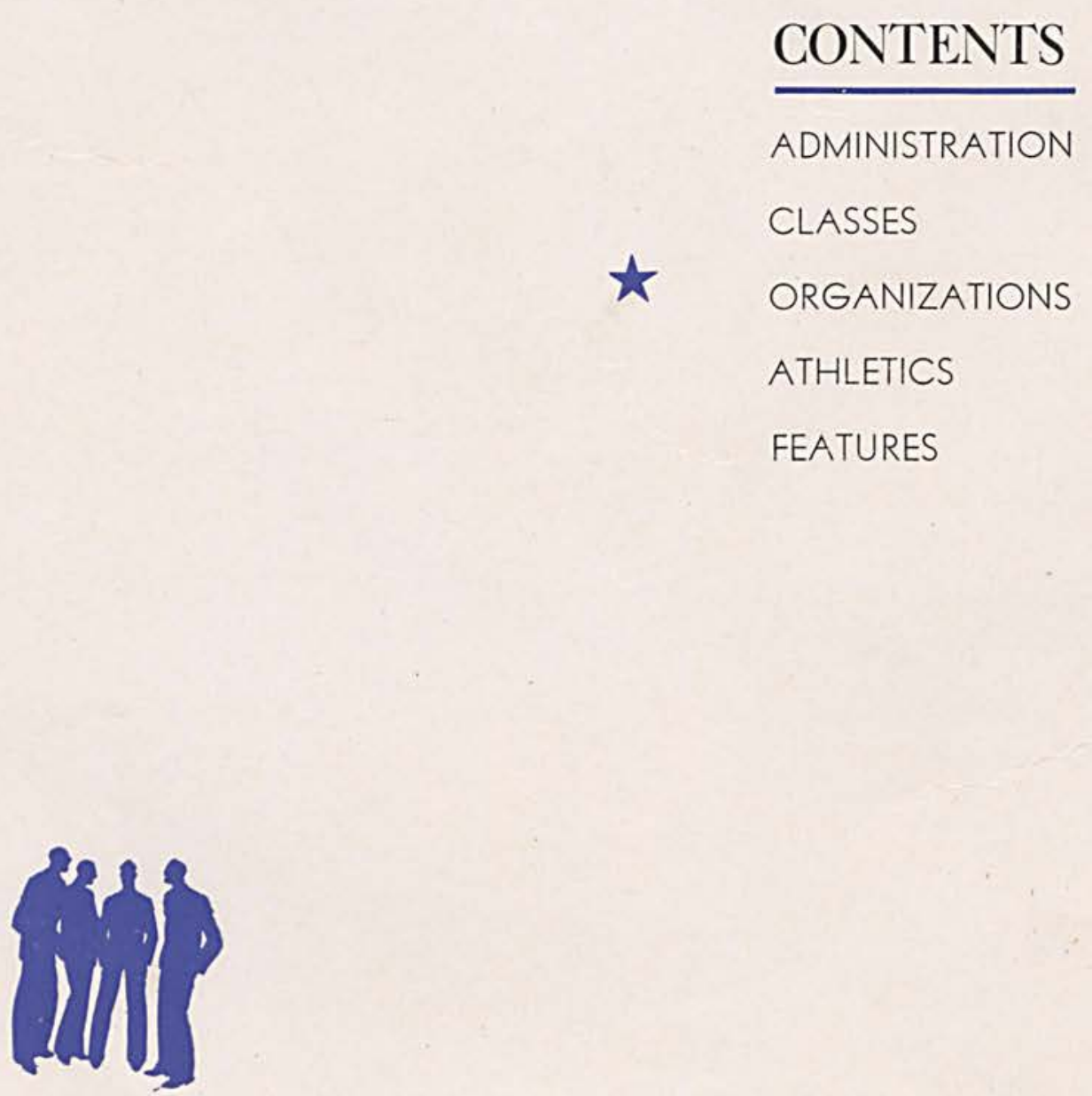


\section{DED I C A T I O N}

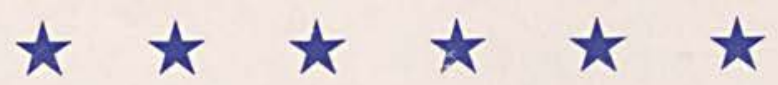

Because your interest in the activities of Cedarville College has endeared you to all the students, because your knowledge and study have commanded their respect, because your idealism has served as a high goal, we dedicate to you this twentysecond volume of the Cedrus.

TO MR. AND

MRS. STEELE,

BELOVED FRIENDS

OF THE

COLLEGE
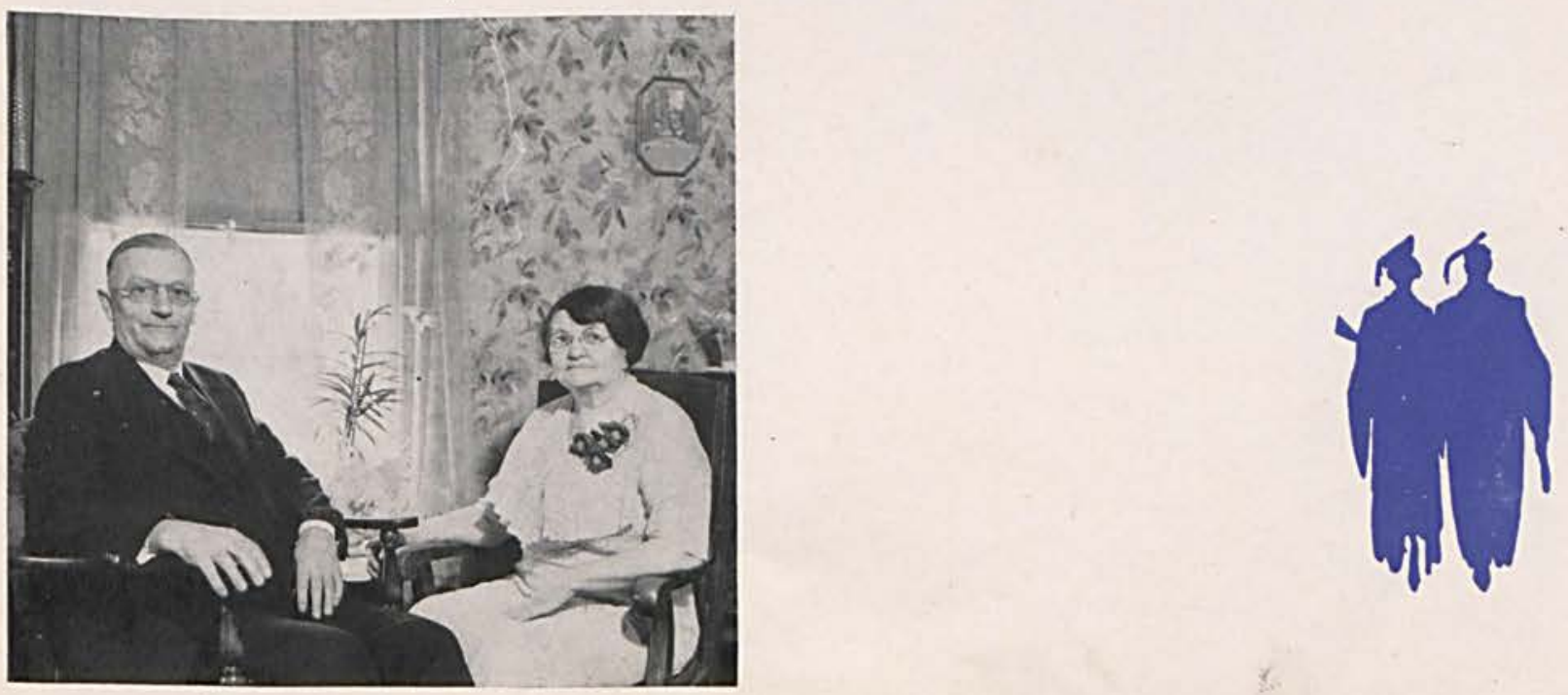


\section{CEDRUS STAFF}

Editor. Joseph West, Jr.

Business Manager. Anna Jane Wham

Asst. Editor. Paul Angell

Asst. Business Manager. . . . . . Do Dorothy Anderson Advertising Manager. .......... Harriet Ritenour Asst. Adv. Manager............ James Anderson Organizations Editor............ Mildred Labig Sports Editor.................. Donald Buehler Music Editor.................. Eugene Corry Art Editor................. Russell Murray Asst. Art Editor................... Ruth Kimble Diary Editor. ................ Mary Johnston Diary Editor................. Joseph Waddle Features Editor ...... . . . . . . . . Justin Hartman Features Editor .................. John Tobias Snapshot Editor. Olive Brill Snapshot Editor................... Hazel Nelson Faculty Advisor. ............ Otto W. Keuhrmann

\section{APPRECIATION}

We appreciate the assistance and cooperation of the faculty and of our fellow students. Space does not permit us to thank all who have contributed to the Cedrus. We wish to thank especially the advertisers for their patronage and also Mr. Milton Fitch for his efforts on behalf of this book. 



\section{BOARD OF TRUSTEES}

Previous to 1928 Cedarville

College was under the control of the Synod of the Reformed Presbyterian Church. At that time the Synod released control to the Board of Trustees. Under their efficient management the college has continued its fine work in Christian education.

\section{Term Expiring 1937}

W. P. Harriman, D.D.

80 Oxford St., Dayton, Ohio

F. N. McMillin, D.D.

2338 Park Ave., Cincinnati, Ohio

W. Clyde Howard, D.D.

1936 S. Michigan Ave., Chicago, III. Judge S. C. Wright Cedarville, Ohio S. Frank Creswell

Cedarville, Ohio

\section{MEMBERS}

Term Expiring 1936

Karlh Bull

Cedarville, Ohio

R. W. Ustick, D.D.

352 S. Belmont Ave., Springfield, Ohio

Wm. Conley

Cedarville, Ohio

Miron I. Marsh, M.D.

Cedarville, Ohio

Wm. H. Tilford, D.D.

21 E. Church St., Xenia, Ohio

\section{Term Expiring 1938}

George H. Hartman

Cedarville, Ohio Walter lliff

Cedarville, Ohio

James L. Chestnut, D.D.

101 N. 12th St., Richmond, Ind.

Wm. R. Graham, D.D.

910 Union St., Lafayette, Ind.

J. Lloyd Confarr

Cedarville, Ohio

W. R. McChesney

President of College, ex officio
President

Dr. W. R. Graham

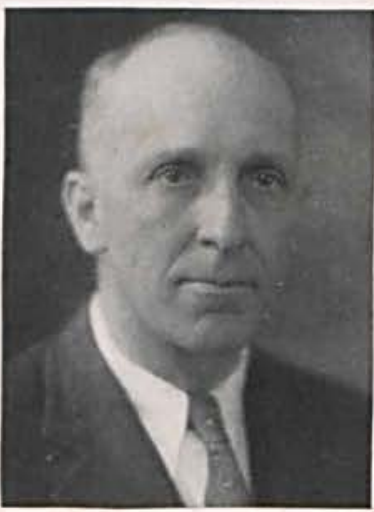

Vice-President Dr. M. I. Marsh

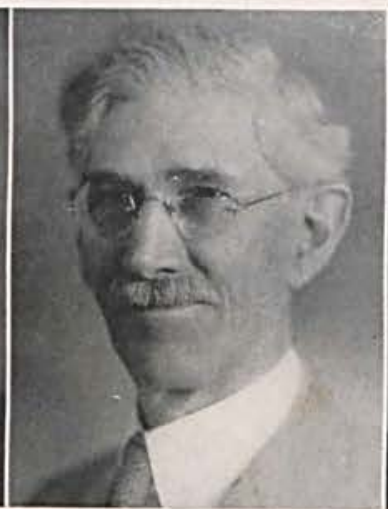

Treasurer Judge S. C. Wright

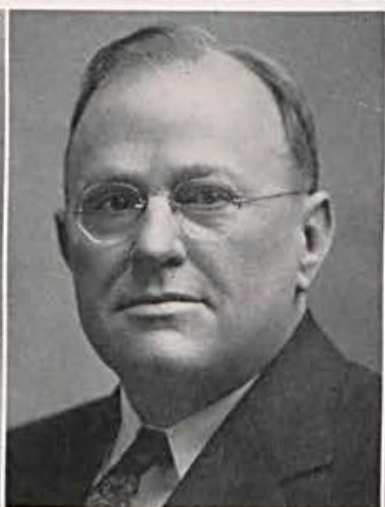

Secretary Wm. H. Tilford

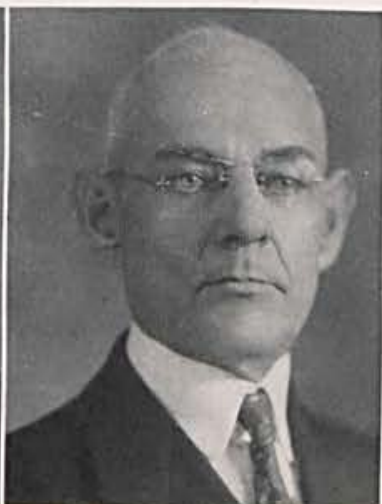




\section{ADMINISRATIVE OFFICERS}

The President of the college, Dr. McChesney, performs many duties. He is an ex officio member of the Board of Trustees. $\mathrm{He}$ sees that the rules and regulations of the Board are carried out with regard to the conduct of the College as well as the regulations of the faculty. The President oversees and supervises the various administrative offices of the College.

The Vice President, J. H. Dickison, has been in very poor health for the last few years and has been unable to be very active during that time. The College holds him in high esteem and hopes for his re. covery.

The Dean of the College, C. W. Steele, has the chief administrative office under the President. In general, he has supervision of the conduct and the studies of the students and is charged with the maintenance of discipline. Besides his administrative duties, Dean Steele is the head of the Social Science Department.

President Dr. W. R. McChesney

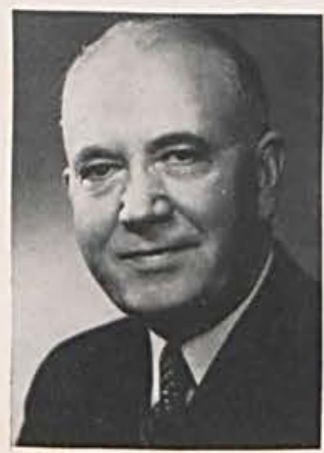

Dean of Men

C. W. Steele

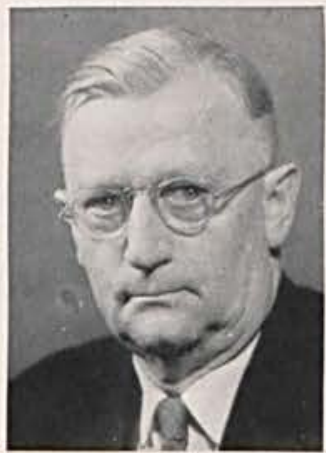

The immediate administrative work of Cedarville College is carried on by the faculty under the direction of the President, W. R. McChesney; the Deans, Prof. C. W. Steele and Prof. Louise Heintz; and the Registrar, Prof. A. J. Hostetler.

The Dean of Women, Mrs. Louise Heintz, supervises the out-of-town girls and gives helpful advice to all the girls in the College. Her other duties are filled as head of the English Department.

The Registrar, A. J. Hostetler, directs the courses of study and arranges the schedule. In addition to these duties, he heads the Education Department.
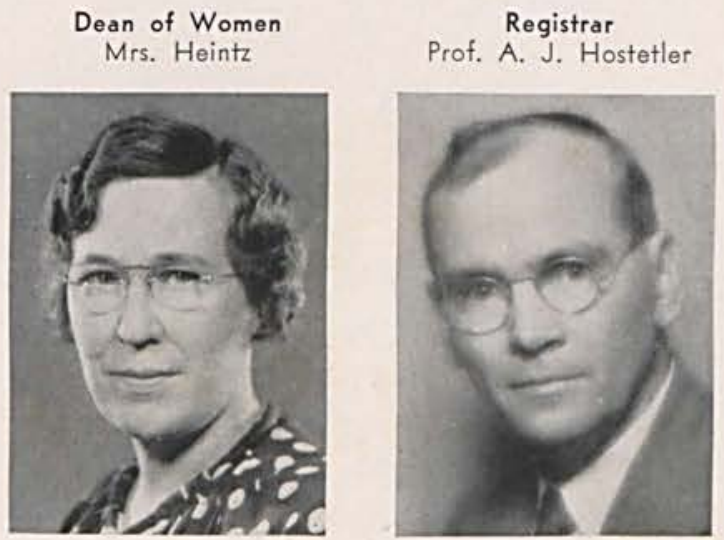


\section{F A C U L T Y}

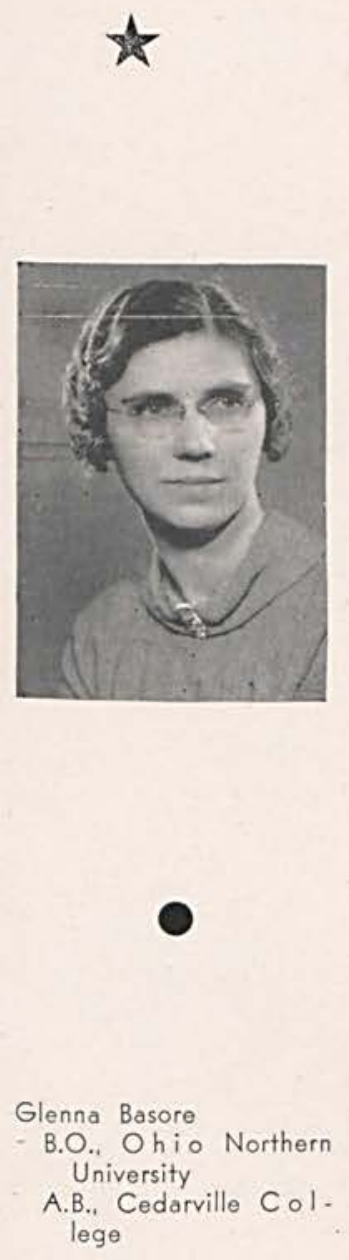

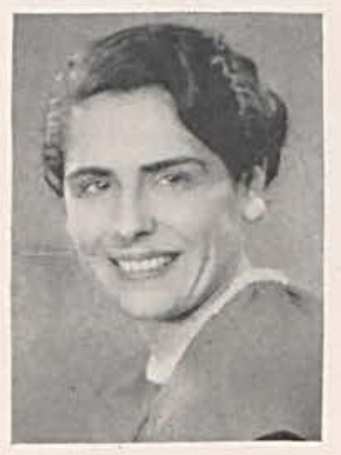

Mrs. Marguerite Covrette Ault

B.S. in Ed., Bowling
Green State College
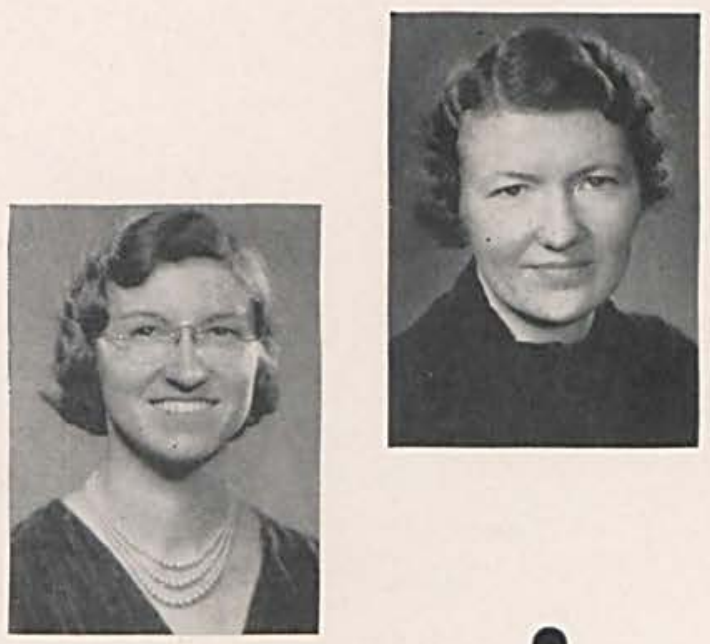

Mrs. Helen Illif Jacobs A.B., Cedarville Col. lege

B.S., O h io State University

Mrs. Margaret Jamieson Work

A.B., Monmouth C o!lege

B.M., Monmouth Conservatory of Music

M.M., Cincinnati Col. lege of Music

Each student at Cedarville College is grateful for the attention and interest in his welfare that the members of the faculty display. We sincerely hope that our work after graduation will bear testimony of this interest. 
Dear Alumi: $\quad$ of the years, forty-one years, giness

vividly to me. and sorrow; but withe course viness, suns very dear a.11 of thy and sadncendant.

some of your number, felicities of the we rejoice in have gone on to them, o so much remain, pre college.

home. Wictory and on for their and college has their to carry an cedarvilie campus, endowalumi, with the years buildings, body has in-

With thessions our student hady have and the re-

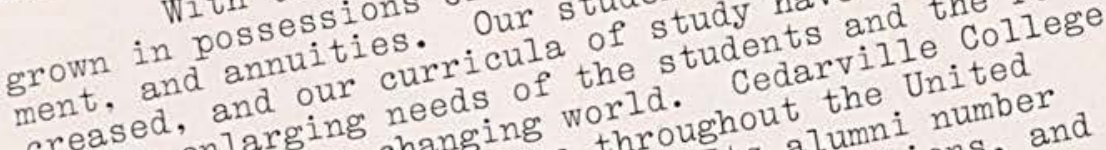

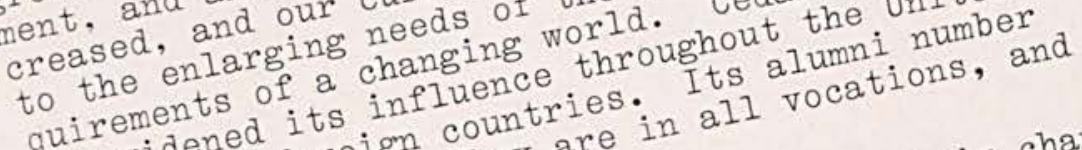
has widened foreign count are in all voy changes states and hundred. the world. in all parts of the wormes have brought their ounders in As changing the faith of right; these things church, and the things lor you, our al

God, the cher and betine love loille college to you and for greand aur genters of cedar sons and daugn closing, the challene and enlarge fellowmen In closing, to continue service to me to cedarvilie collego of Cedarviloory of God.

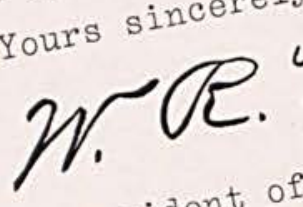

college office, ohic

Cedaril 16,1936 



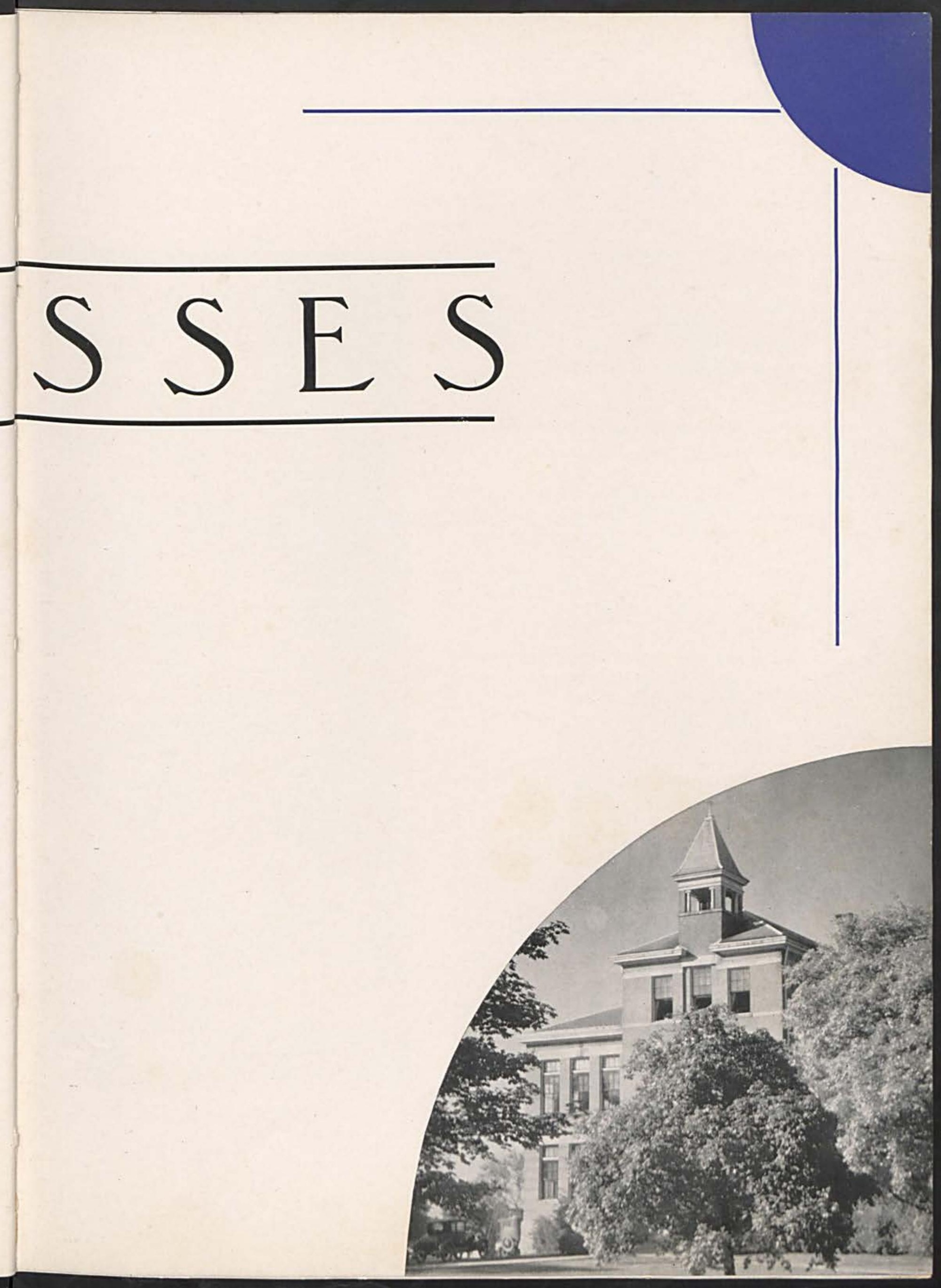




\section{SENIORS}

As senior president and editor of our college paper, the "Whispering Cedars," "Russ" has been a prominent figure in the college activities of ' 36 . $\mathrm{He}$ has filled offices in the Y. M. C. A. and in the Literary Society. As a member of the Student Council, he was vice president in '36. He has been a member of the Cedrus, Junior, and Senior play casts.

Much credit for the success of this book should go to our editor-in-chief. "Joe" has participated in the Dramatic Club, Delta Kappa Sigma, Literary Society, Mixed Chorus, Debate, and Y. M. C. A. Besides being president of the Student Body, he has played prominent roles in the Cedrus, Junior and Senior class plays.

Our Cedar Queen of ' 36 has been prominent in the music department of the college. As a member of the Y.W. C. A., she served as hostess in ' 35 and as president in '36. She has participated in both the Junior and Senior plays.

Our Cedar Day orator of ' 36 has participated in the Y. M. C. A., Literary Society, Debate, and Mixed Chorus. He has served as a class officer 3 , and on the Cedrus Staff 2, 3. Besides the above. he was baseball manager in ' 34 and a member of the casts presenting the Junior and Senior class plays.

By her ability and willingness to work as a member of the Y. W. C. A., Student Council, Cedrus Staff, Glee Club, and Mixed Chorus, Olive has earned the admiration and respect of the entire college. She also was in the Mock Weddings of ' 35 and ' 36 , and in the Junior and Senior class plays. Her hard work won for her the Crown Club membership in ' 34 .

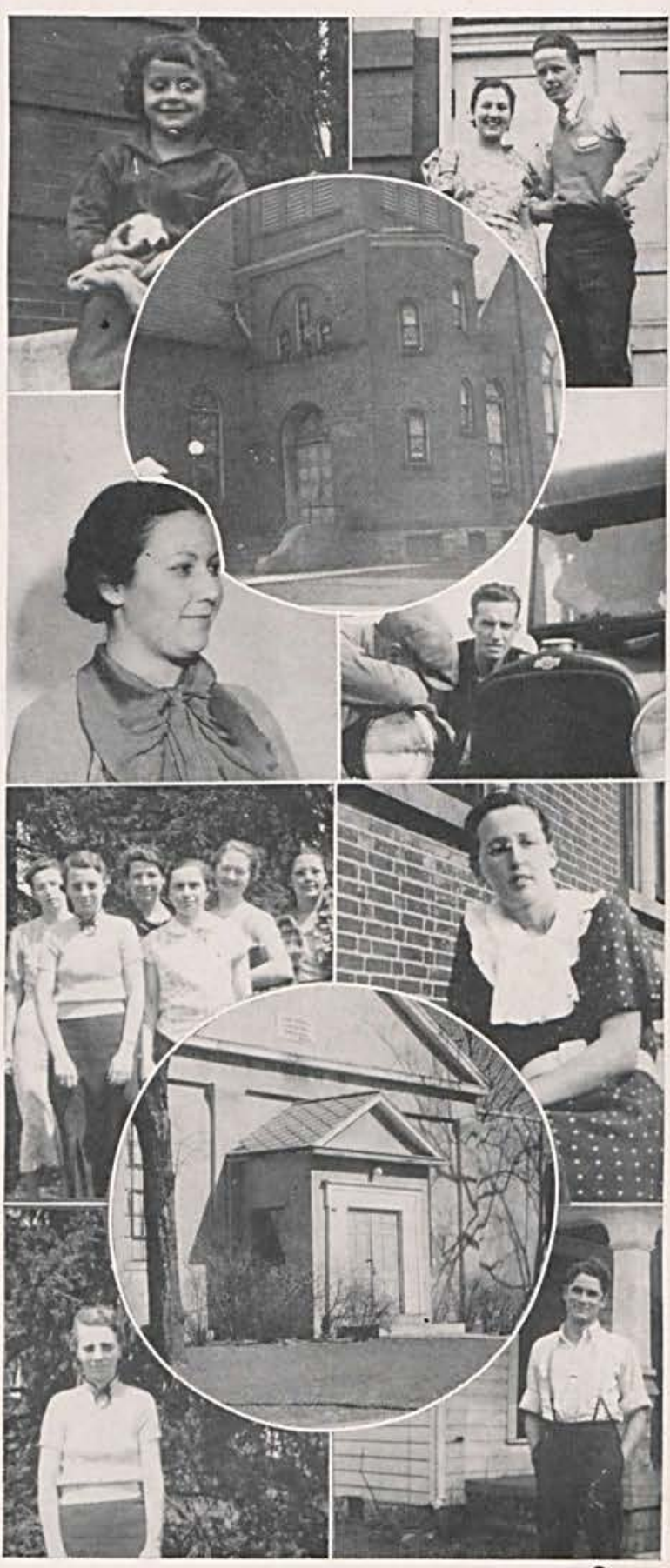

SENIORS, FRIENDS, 


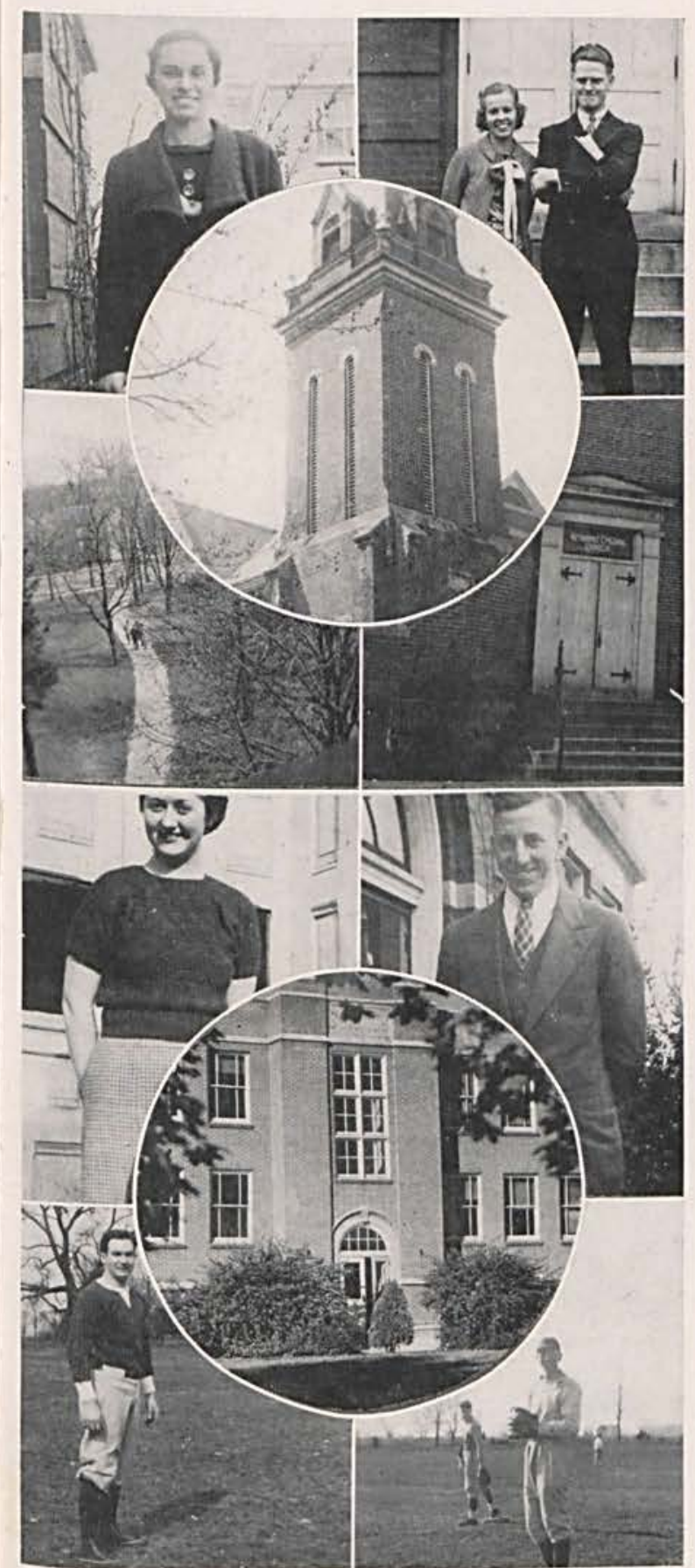

AND VIEWS
Being exceptionally fond of sports, Buehler has served efficiently as sports editor for both the "Whispering Cedars" and the Cedrus of "36. Because of this interest, he served as basketball manager in '36. He has been a member of the Y. M. C. A. and the Literary Society and played in the Junior-Senior class plays.

Dorotha, our Y. W. bride, has served efficiently as pianist to the Choral Clubs of the college. She has been a member of the Y. W. C. A., participating in the traditional Mock Wedding. As a member of the Cedrus Staff in '34, she played in the Cedrus play and also in the Senior Class play.

Eugene, being talented in the field of music, has been prominent in the music department. He was a member of the Y. M. C. A., serving as program chairman. Besides participating in the Bible Reading Contest, he directed the music of the Y. M. Minstrel of '36. He was a member of the tennis team.

The music department of the college would have suffered without the bass voice of Garlough. In the field of athletics, he took a prominent place in both basketball and baseball. He took part in our class plays and was a member of the Student Council and of the Y. M. C. A., acting in the $Y$ Minstrel.

Mildred, our Y. W. groom, has served efficiently in the Y.W. C. A. as a member of the program committee of '36. She was a member of the Literary Society, Glee Club, and Dramatic Club. She took a prominent part in the Junior and Senior Class plays. She was a member of the Cedrus Staff of ' 36. 


\section{GRADUATES OF}
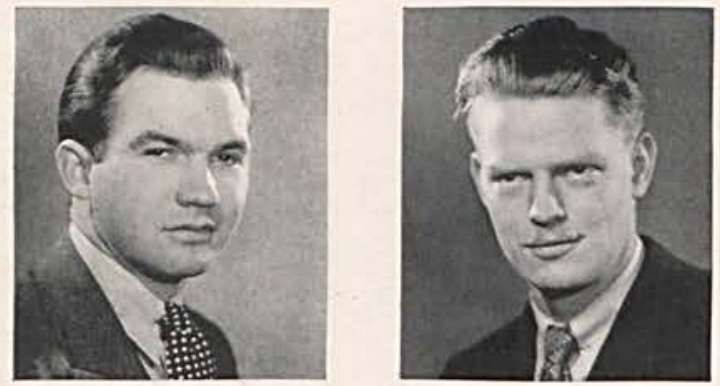

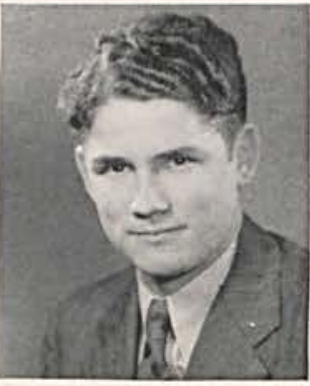

President
Russell Murray
Graniteville, Vermont

Vice-President

Joseph S. West

Cedarville, Ohio

\section{Secretary}

Anna Jane Wham Cartter, Illinois
Treasurer

Donald Burkert Columbus, Ohio
The Senior class in the past four years has by the effort of its members made itself an essential part of the College. Although this is their last year, it is their hope that they leave to the undergraduates a high standard for them to better.
Julia has been a faithful member of the Y. W. C. A. and the Literary Society. She graduated from the two-year normal in '34. She was a member of the casts presenting the Junior and Senior class plays.

Paul has been a member of the Y. M. C. A. and Literary Society during his four years of college work. He also was a member of the casts presenting the Junior and Senior class plays.

One of the best known seniors is Paul. He was a member of the baseball squad his Junior and Seniors years. In his Senior year he was tamed by Mary and became domesticated.

In the music department, Harriet has filled a prominent place. She became a member of the Crown Club Society of ' 35 for scholastic achievement. She was a member of the Dramatic Club, Literary Society, and Y. W. C. A., serving as a cabinet member. She served on the "Whispering Cedars" and Cedrus staffs and participated in the Cedrus, Junior and Senior class plays. 


\section{NINETEEN THIRTY-SIX}

Donald Buehler

Forest, Ohio

Eugene Corry

Clifton, Ohio

○

Julia McCallister

Cedarville,Ohio

-
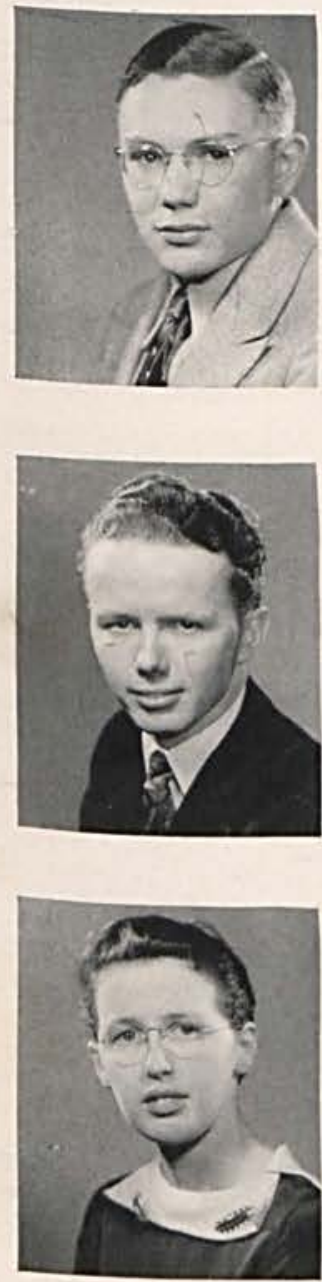

Olive Brill

Newport, Kentucky

Verner Garlough

Pitchin, Ohio

Paul Reed

Cedarville, Ohio

$\bullet$
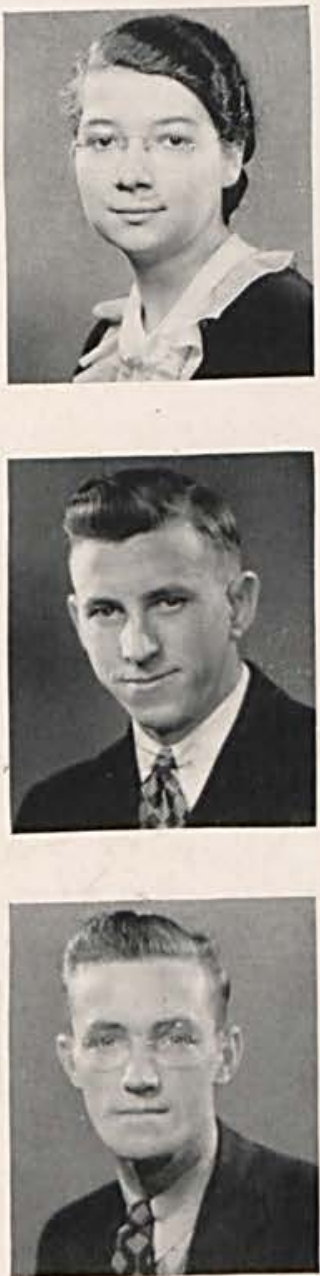

Dorotha Corry

Cedarville, Ohio

Mildred Labig

Tippecanoe City, Ohio

Harriet Ritenour Cedarville, Ohio
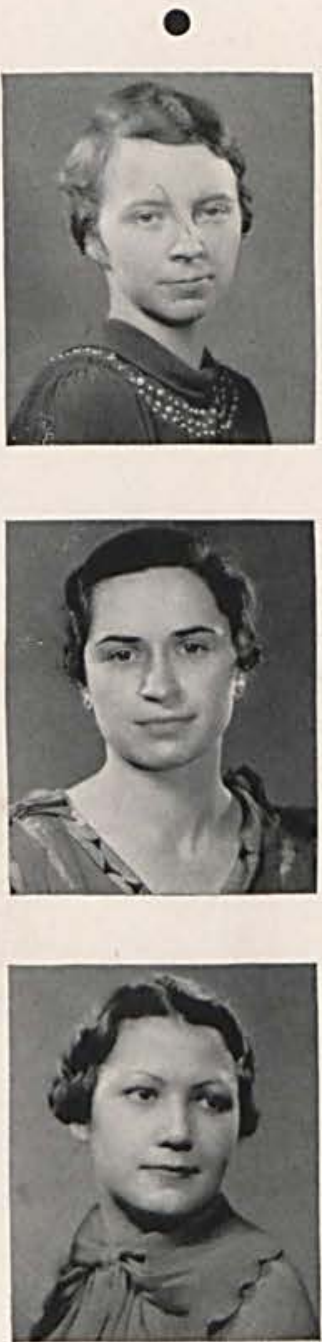

SENIOR HISTORY

Four years ago thirtyseven bewildered freshmen entered Cedarville College for the first time. Our confusion was further increased by the trials of freshman week. Nevertheless, under the leadership of William Reed, we managed to adjust ourselves to college life.

The next year only twentysix returned and choosing Errol McKnight for our president, we entered with confidence all the fields of college activities.

Under the leadership of Russell Murray, we found our twenty Juniors a busy group indeed. It meant a lot of cooperation to put over the Junior-Senior Banquet and our class play entitled "Shirt Sleeves."

At the beginning of our Senior year, we reelected our Junior officers, refilling the vacancies. Among other activities, our class enjoyed a covered-dish dinner and theatre party. Our class play, "Big Hearted Herbert" will close our participation in the activities of Cedarville College. 

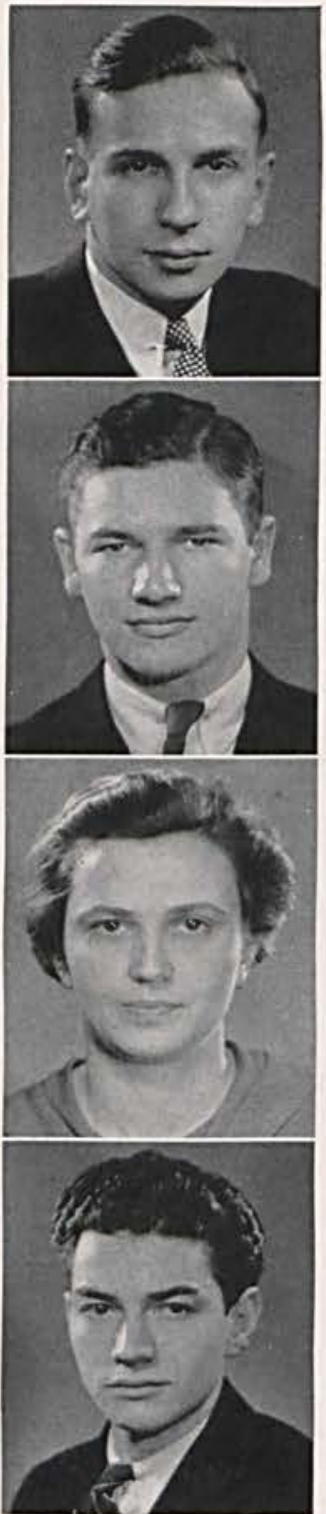

President

Paul Angell Dayton, Ohio

\section{Vice-President} Gale Ross Cedarville, Ohio

\section{Secretary}

Esther Waddle Springfield, Ohio

Treasurer

John Tobias

Cedarville, Ohio

\section{JUNIOR HISTORY}

With last good-byes, words of advice, and a very "scared" feeling, forty Freshmen boarded the train of events in September, 1933 for a four-year trip. That year we had as our conductor, John Richards. Very much to the embarrassment and the surprise of the Sophomores, the "little Freshies" won the annual tug-of-war. This was the first time for many years that the Freshmen had succeeded in conquering the Sophomores. Another thing that proved that our class was unusual was the fact that the Freshmen succeeded in having two parties without the usual interruptions of the upper classmen. During this year our class contributed three members to baseball and basketball. These members were: Joe Waddle, Harry Wallace, and Gale Ross. By the end of this year we began to feel as though we were really college students.

In the fall of ' 34 we again boarded the train, this time with a little more confidence in ourselves. Edwin Potee conducted us through this year. Our class took an important part in all of the activities of the college. At last we had become "somebody" and were no longer spoken of as "green Freshies."

At the end of this year several of our members went either into the car ahead or became engaged in their life work.

This year, headed by Paul Angell, we seem to be speeding along fairly well. Our class play "Forever True" was given both here and in Carlisle. The most important event of this year was the Junior-Senior Banquet. It was held at the Dayton Y. M. C. A. on Wednesday evening, May 13. The general theme of the banquet was "The Launching of the Ship." After the dinner and the program the group attended Loew's Theatre where we saw "The Unguarded Hour."

We are eagerly looking forward to the last year of our trip and we sincerely hope that we may reach our destination without any serious mishaps. 


\section{CLASS OF 1937}

Dorothy Anderson

Cedarville, Ohio

Mildred Beard

Bowersville, Ohis

Gladys Bumgarner

Mount Sterling, Ohis

Mary Helen Creswell

Cedarville, Ohio

Betty Fisher

Chicago, Illinois

Clarence Gray

Albert Grube

Ruth Hoke

Ruth Kimble

John Richards

Joseph Waddle

Harry Wallace

Lawrenceville, Ohio

Cedarville, Ohio

Clifton, Ohio

New Carlisle, Ohio

Cedarville, Ohio

Cedarville, Ohic

Cedarville, Ohio

$\begin{array}{lll}\text { Anderson } & \text { Beard } & \text { Bumgarner } \\ \text { Creswell } & \text { Fisher } & \text { Gray } \\ \text { Grube } & \text { Hoke } & \text { Kimble }\end{array}$

Richards

Waddle

Wallace
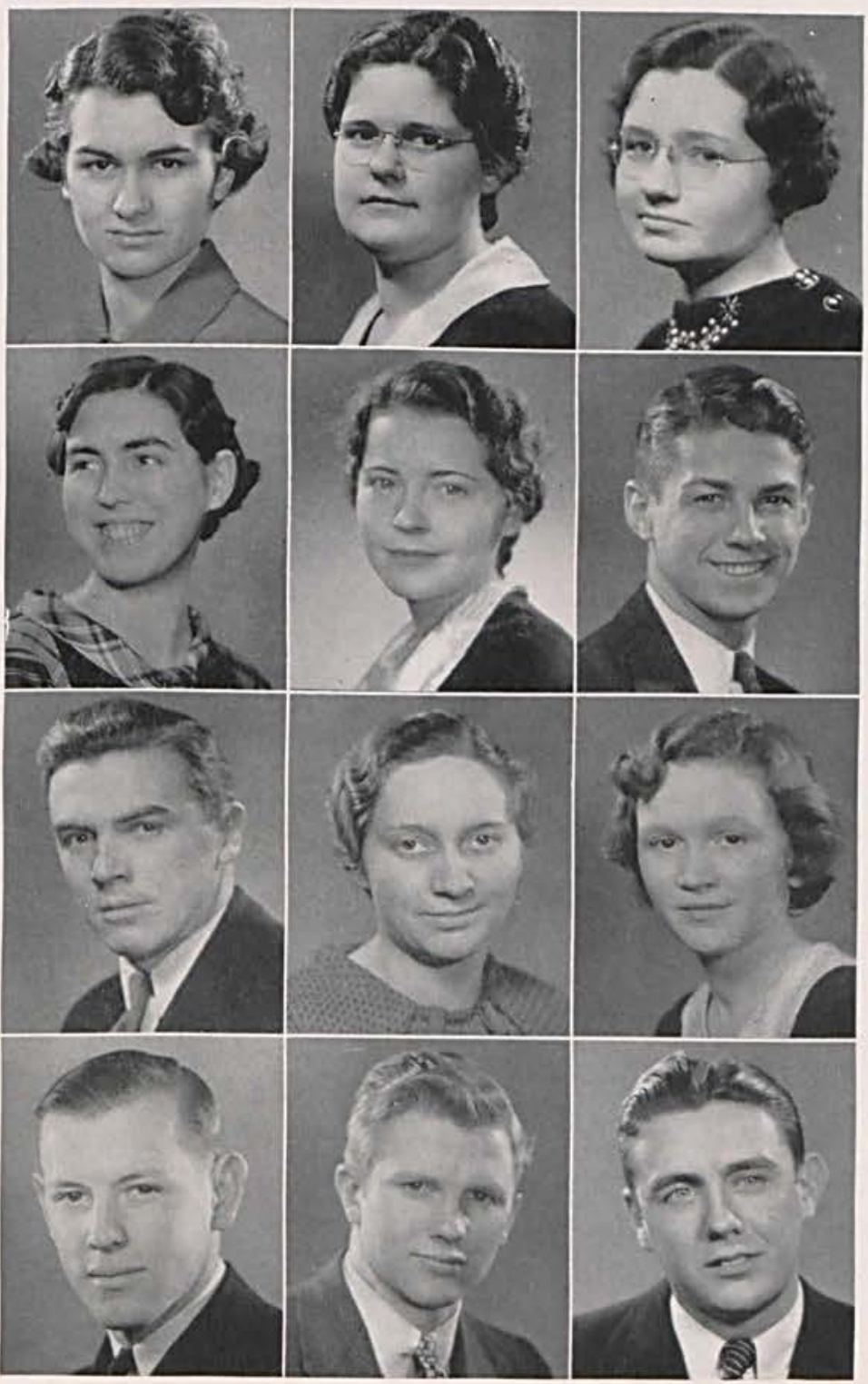

Page Twenty-one 


\section{SOPHOMORES}
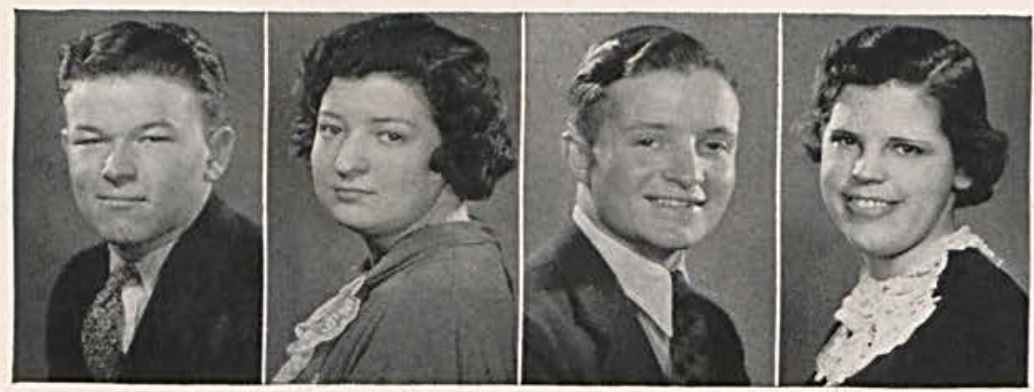

\section{CLASS OFFICERS}

John Gillespie

President

Edna Brill

Secretary

Max Michael

Vice-President

Jeanne MacKnight

Treasurer

\section{SOPHOMORE CLASS TRADITIONS}

\author{
Entered Cedarville College \\ Elected Class Officers \\ Feed at Anderson's \\ Feed at Cliffs \\ Feed at Gun Club \\ Best Freshman Class Disappears
}

\section{SOPHOMORE HISTORY}

"All aboard!" shouted the conductor. Fortyfour sophomores answered the summons and climbed aboard. We were all anxiously waiting to begin our second annual journey through the land of knowledge. Our journey this year was not so difficult as the one preceding since we had become accustomed to changing scenes. We found new lands to explore, new mountains to climb, and pleasant sights awaiting us on every side. All was not ease and pleasure, but we were better prepared to withstand these hardships.

A change had been made in the crew which manned our train. Those who carried us through a successful journey last year were: James Anderson, Eugene Reed, Christina Jones, and Eugene Haughey. This year another crew arrived to follow a new course. The members of the new addidition, John Gillespie, Max Michael, Edna Brill, Ethel May and James Anderson have kept eyes forward and the train upon the rails.

The conductors of our train (of thoughts) found us willing to show forth our colors in all activities to which they presented us, athletics, dramatics, clubs, music, and those things which not only brought us pleasures but benefits as well. One very pleasant stop on the first part of the journey was at "Pastime Hall" (college gym). It was the first gettogether of the year for the class and its friends. Another stop was spent on the snow crusted hillside of the Knott homestead. 


\section{L A S S OF 1938}

Whenever we came upon our friends and fellow explorers, the freshmen, we were kindly asked to joint them, to which we gratefully accepted. We tried to be good sports and bear our share of the responsibility of the journey.

A few have dropped along the way but we have kept on with a smile. At the end of this year's journey we shall reach a parting of ways, some to come back again next year, and others to journey into life to become conductors of other trains.

To the Sophomores of ' 36 and the Juniors of ' 37 we say, "If you have not been successful in ail undertakings this year, strive harder. Next year start with a clean slate and do your best."

\section{SOPHOMORE TRADITIONS}

Gathered as "Sophs"

Ducked the "Freshies"

Anderson Wins Contest

Feed at Gym

Coasting at Knott's

Madgel Ties in Contest

Part at Commencement

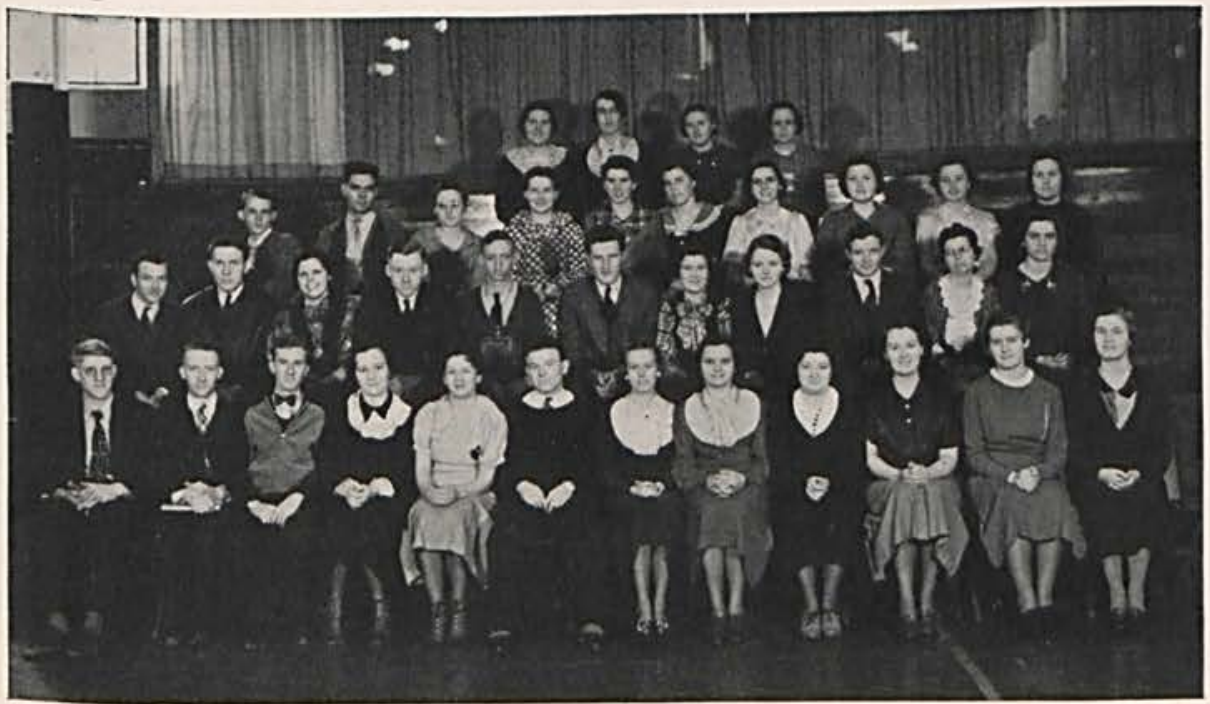

SOPHOMORE CLASS

First Row: Shaw, Hoke, Cummings, M i 11 e r, Post, Gillespie, Nels o n, Jones, Bril1, Johnston, Batdorf, Creswell.

Second Row: Reed, Long, MacKnight, Sanders on, S in ks, Swaim, Hageman, Porter. Michael, McKenzie, Kline.

Third Row: MeCorkell, Anderson, Allison, Smith, Mc. Dorman, Shaw, Ackerman, Olinger, Clouser, Miller.

Fourth Row: Bryant, Mossman, May, Alexander. 


\section{F R ESHMEN}
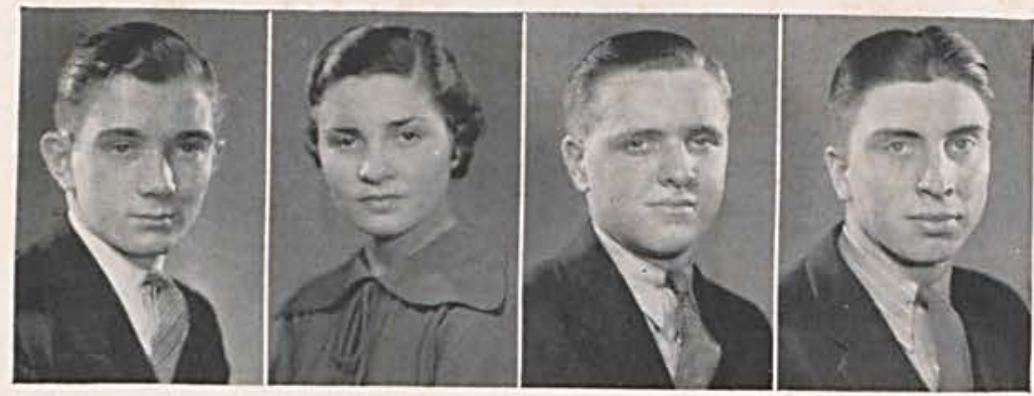

\section{CLASS OFFICERS}

Fred Heifner

President

Roy Linton

Vice-President

Cletis Jacobs

Richard Smith

Secretary

Treasurer

FRESHMAN TRADITIONS

Freshman Week

Long Walks Home

Freshmen Walk Backward

No Chaperon at Feed

Water at Willow Bend

Girls Scrub Steps

Suffer Through Exams

Pajama Parade

\section{FRESHMAN CLASS HISTORY}

On September 10, sixth-five ambitious Freshmen entered Cedarville College. This class is proud to boast having the largest number of students in the history of the College.

The upper classmen greeted us with a week of initiation. This included the girls wearing green hair ribbons and aprons, the boys using makeup, and all Freshies walking backwards on the campus. The last day of initiation week the freshmen gave a chapel program for the entertainment of the upper classmen, and the tug-of-war was held at Willow Bend. (The Freshies got wet.)

Our first meeting was held to elect officers. Those chosen were: President, Frederick Heifner; Vice President, Roy Linton; Secretary, Cletis Jacobs; Treasurer, Richard Smith.

Our first feed was a success, despite the fact that it rained and the upper classmen helped us with the eats.

The second feed was at the home of our president, Fred Heifner. It ended by the freshmen ditching the upper classmen and going to a show. 


\section{CLASS OF 1939}

This semester, we have had one party which was at the home of the Kendig twins, near Xenia. The upper classmen were there to greet us when we arrived and shared the eats with us.

When basket ball season opened, a good number of Freshmen turned out for practice. Linton, Walker, Gibson, Smith, and Thomas made the first ten with Gibson and Linton playing on the first team. The freshmen produced a fine team for the intramural tournament. In their first game they defeated the Seniors by a large score. The winner of the Sophomore-Junior game being the Sophomores, the Freshies met them in the second game, and winning this, took the tourney.

Six Freshmen were awarded basket ball letters: Walker, Linton, Gibson, Smith, and the two Freshman cheer leaders, Helen Seamon and Cletis Jacobs.

The class also contributed much good material to the college baseball team in the playing of Jackson, Walker, Linton, Thomas, and Thompson.

Practically all the Freshmen are active in Y. M. and $Y$. W. work and many are in the music department.

The Freshmen are very proud to have one mem. ber of their class on the College Debate Team. This student is Justin Hartman.

Since we have had such a successful Freshman year, we will look forward to an active and equally successful Sophomore year.

\section{TRADITIONS}

Basketball, Baseball, and Debate

Romeos and Juliets

Justin Throws Cake

Parties for College

Party Then Show

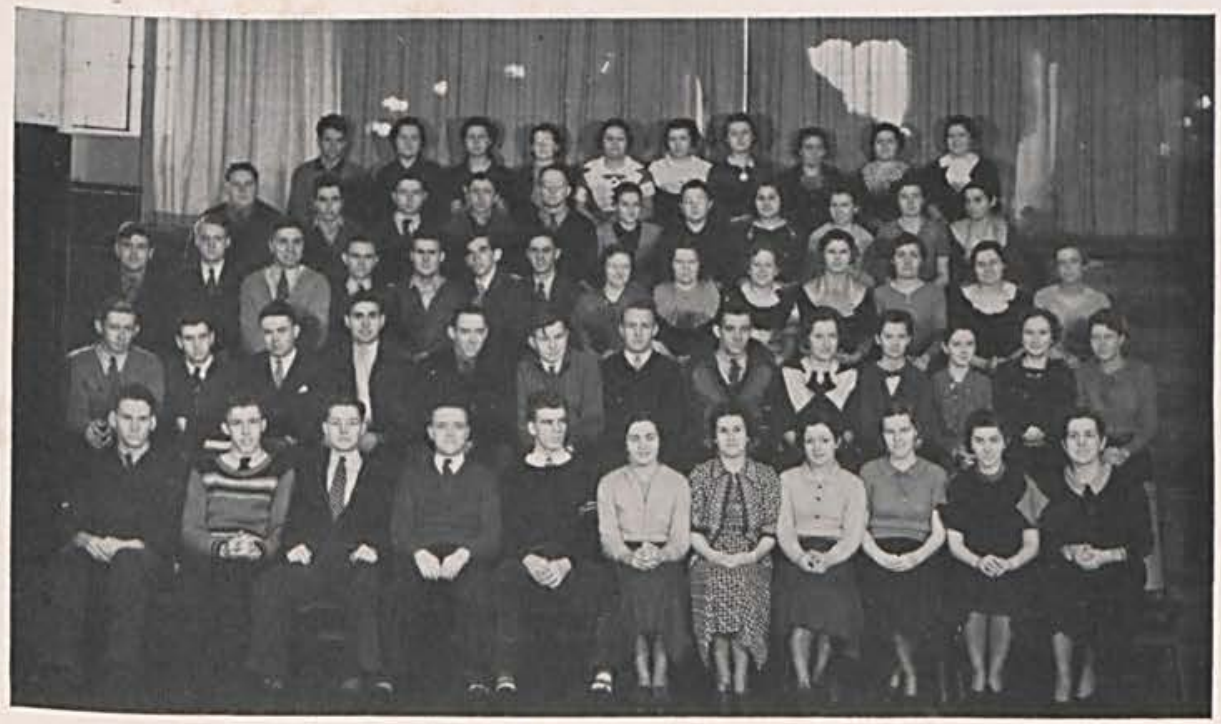

FRESHMAN CLASS

First Row: Thomas, Hartman, Lott, Linton, Walker. Jacobs, Hughes, Seamon, Long, Graves, Holland.

Second Row : McDonald, Ford, Floyd, Faulk, Gibson, Murray, J o h n son, Heifner, Watkins, Michael. Nels on, M. Smith, L. Smith.

Third Row: Prescott, Sharp, R. Smith, Sisson, Jackson, Thompson, Shaw, Frame, Cooley, Tindall, Waddle. Flet cher, M c Clellan, Grimes.

Fourth Row: Berk, Schwarm, Flory, Allison, Beals, Tobias, Kimble, E h m a n, Flory, Tipton, Collins.

Fif th Row: Tomlinson, Richards, Lott, Kendig, Kendig. 


\section{SPECIAL STUDENTS}
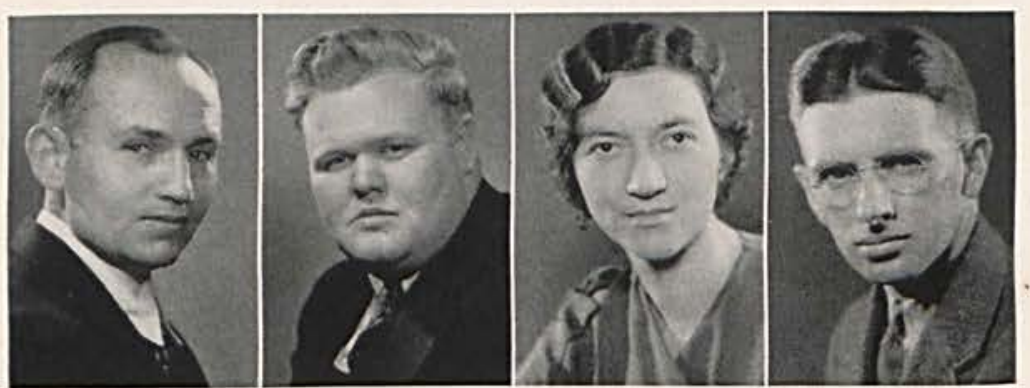

Forrest Nagley

Cedarville, Ohio

Franklin Trubee

Cedarville, Ohio

Elsie McLaughlin

Cedarville, Ohio

Paul McLaughlin

Cedarville, Chio

Forrest Nagley is taking educational work. $\mathrm{He}$ was formerly a research chemist but came back to Cedarville College to enter the teaching profession.

Franklin Trubee is in the Seminary. He graduated from Cedarville College with the degrees of A.B. and B.S.
Elsie McLaughlin is taking religious work in the college.

Paul McLaughlin is in the Seminary. He graduated in 1934 with an A.B. He was ordained in the spring.

\section{SEMINARY}

The Theological Seminary being one of the oldest departments of Cedarville College was founded more than a hundred and twenty-five years ago. Its purpose has been the training of Christian youth for the ministry.
At present its student body numbers two, but others are being influenced by the Seminary as members of its Gospel Team, the "Monk's Club." Students of the Seminary participated in the student communion service on Good Friday, and have taken active part in the College Y. M. C. A. 





\section{CEDARVILLE COLLEGE}

O Cedarville, our college dear, For loyal youth so strong,

For constant faith without a fear, Through all the years so long!

O Cedarville! O Cedarville!

Home of our student days,

Forever may thy name abide

And lasting be thy praise.

O Cedarville, we love thy halls Where precepts true are sought; We love thy consecrated walls Where earnest youth are taught.

O Cedarville! O Cedarville! Joy of the by-gone hours, Continue through the passing years, And reach your hoped-for powers.

O Cedarville, we live for thee With faith unfaltering -

We live, we love, we trust for thee; Be glad and let us sing

O Cedarville! O Cedarville!

Our trust in thee maintain:

Confirm thy strength in purity,

Thy honor to retain.

O Cedarville, we pray for thee Our God will love and care In days of stress in years to be $O$ hear, $O$ God, our prayer;

For Cedarville! For Cedarville!

Preserve her in thy grace;

Defend her with thy mighty hand, Shine on her with thy face.

President W. R. McChesney. 


\section{STUDENT COUNCIL}

By the ruling of the administrative office of the college the Student Council of Cedarville College was chosen to consist of the following members: the President of the college, the college Deans, the officers of the student body, and the presidents of the four classes. This Council was to have charge of those things pertaining to student government. The President of the Student Body was authorized to act as Chairman of the Council.

This year among other duties the Council planned a party in honor of the Freshman Class of ' 36. The party was in the nature of a hike and ended in a wiener roast on the college Campus. One of the most interesting features of the Council was the sponsoring of our college paper "The Whispering Cedars." Following complaints the Council arranged a parking schedule which was later vetoed by the student body.

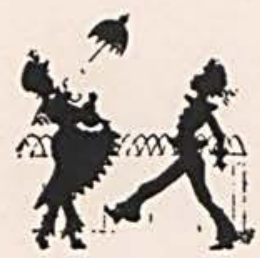

MEMBERS

W. R. McChesney............President of college C. W. Steele... . . . . . . . . . . . . Dean Louise Heintz. . . . . . . . . . . . . . . . . Dean Joseph West............ Student Body President Olive Brill. ............. Student Body Secretary L. Russell Murray............... Senior President Paul Angell................. Junior President John Gillespie............ Sophomore President Fred Heifner. . . . . . . . . . Freshman President

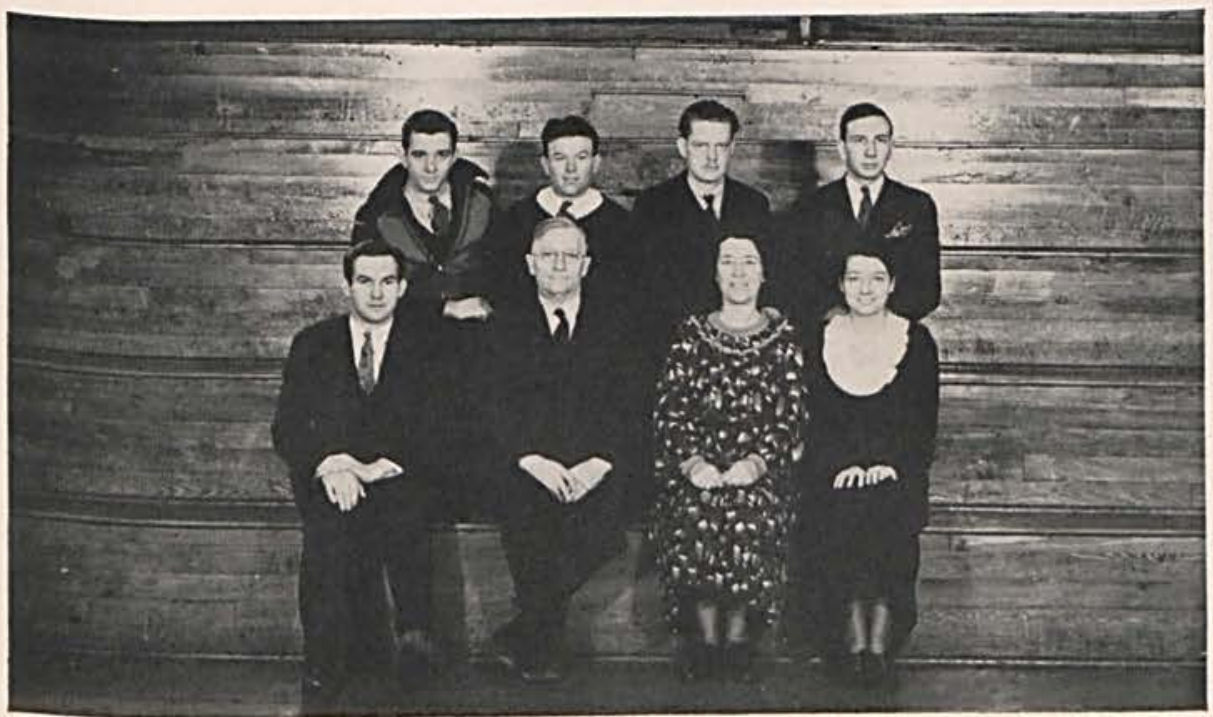

STUDENT COUNCIL

First Row: Murray, Steele, Heintz, Brill.

Second Row: Heifner, Gillespie, West, Angell.' 


\section{CEDRUS STAF F}

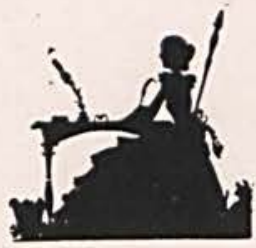

The past few weeks have found a busy staff indeed, as we have worked to construct the 1936 Cedrus. Cameras have been clicking and typewriters humming in gathering material to fill the college annual. The work will soon be completed as far as the staff is concerned. It has been our desire to publish a book that will contain a source of memories for years to come.
While the staff under the direction of the editor and guidance of the faculty advisor has been credited with the actual publication of this book, the work of students, alumni, photographer and publishers has been necessary for its successful completion. The staff is grateful to all who have in any way helped them in its publication. We extend a word of thanks to the business men who have assisted in the financing of this task.

The staff offers the Cedrus of 1936 with the hope that it may serve as a lasting record of college life during the past year. May its pages become worn through use. To those leaving the halls of Cedarville College may it be the cord that binds them to their Alma Mater. May it be a memory book to which they may go to the past.
CEDRUS STAFF

First Row: Hartman, Rite. nour. Murray, Wham, West, Angell, Labig, Anderson.

Second Row: Anderson,

Buehler, Kuehrmann, To.

bias, Waddle, Nelson, Brill,

Johnston, Corry, Kimble.

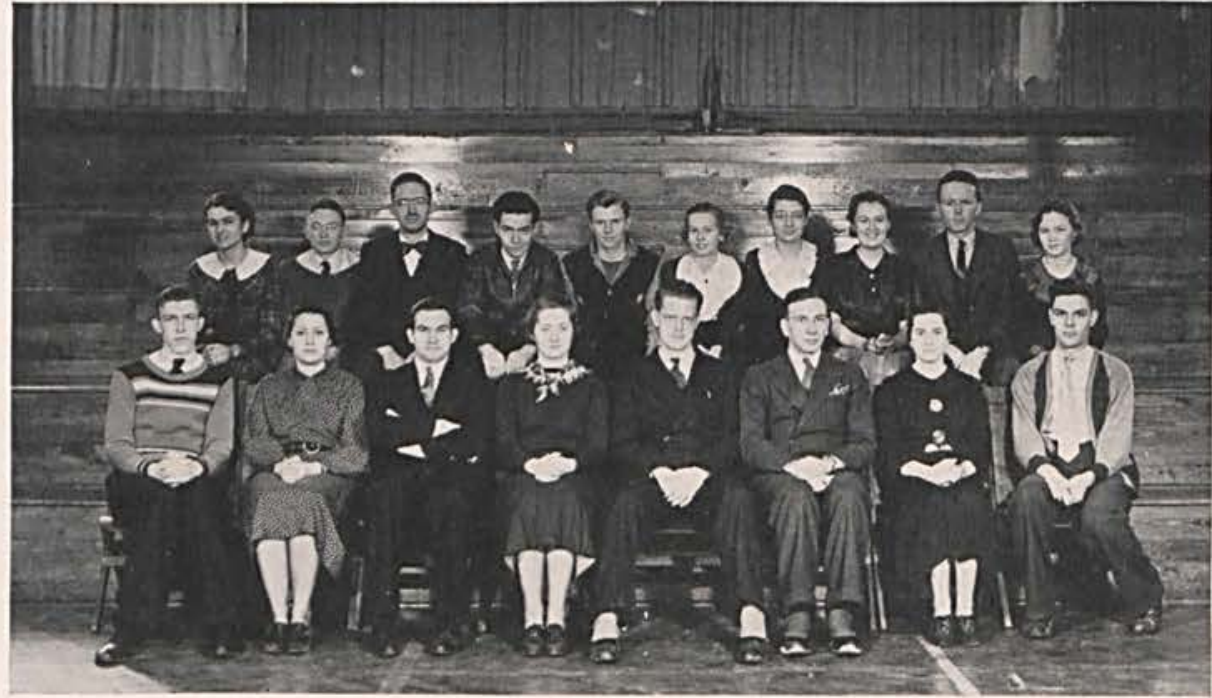




\section{CEDRUS PLAY}

On December 10, the Cedrus Staff presented "The Quest". The play was of a serious type but it proved highly entertaining and was well presented.

Caleb Armstrong, a once wealthy man, had the misfortune to be caught in the stock market crash shortly after his youngest son had been severely injured. The story of Caleb's struggle proved to be a very interesting story.

Julien, his elder son, just entering college, and his two daughters, all somewhat pampered by riches, proved themselves "true blue" and helped their father win back his fortune. Mrs. Mulligan provided the laughter to the play. Herbert, friend of Constance, learned a real lesson in living.

The success of the play is largely due to the able direction of Miss Glenna Basore.

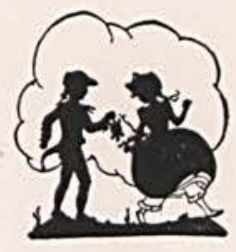

CAST OF CHARACTERS

Caleb Armstrong............... Joseph West His Wife, Sylvia............. Harriet Ritenour His Daughter, Constance............ Hazel Nelson His Son, Julien.................. Russel Murray His Daughter, Wenda............. Ruth Kimble Herbert Ross, friend of Constance.... John Tobias Dr. Wood, family physician...... James Anderson Mrs. Pat Mulligan.......... Dorothy Anderson

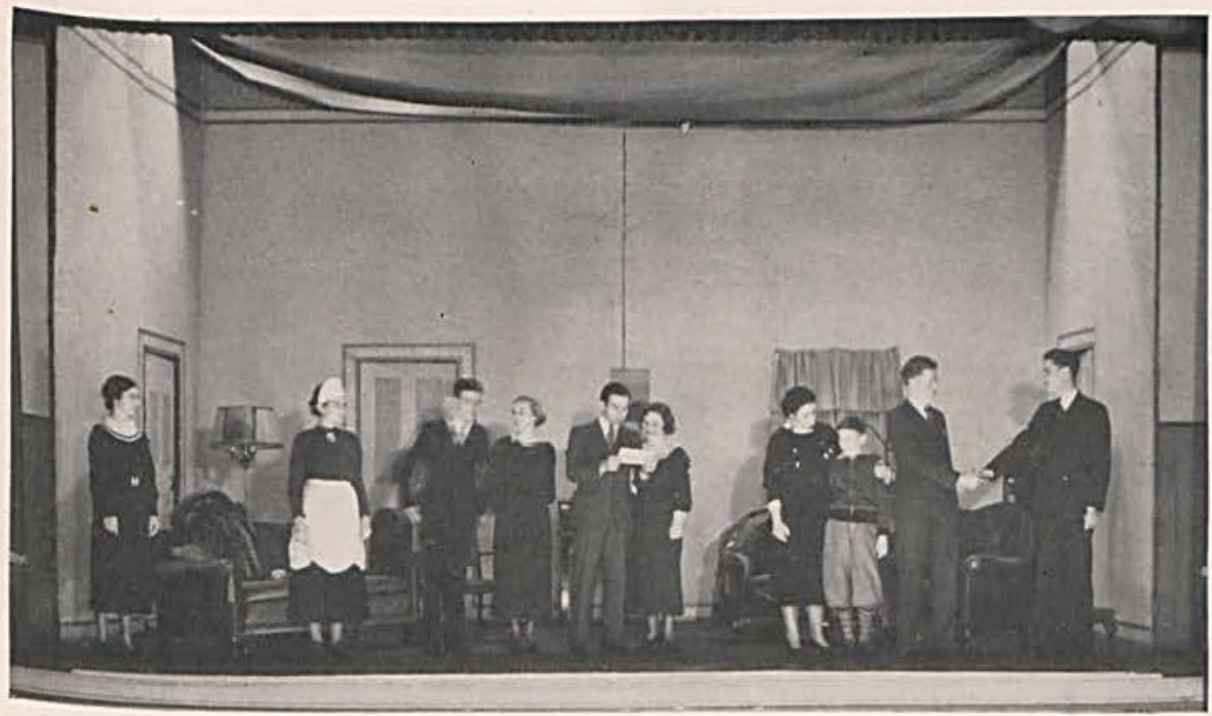

\section{CEDRUS PLAY}

Basore, Anderson, Tobias, Nelson, Murray, Kimble, Ritenour, Wright, West, Anderson. 


\section{WHISPERING CEDARS}

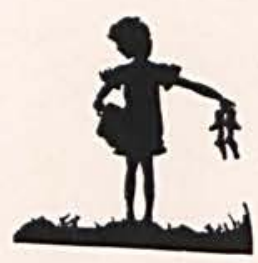

STAFF

Editor-in-Chief. ............... Russel Murray

Assistant Editor. . . . . . . . . . . . . Franklin Trubee

Business Manager............ James Anderson

Sports Editor.

..Donald Buehler

Features Editors. . Harriet Ritenour, Justin Hartman Art Editors.......... Gladys Olinger, Ethel May Chief Typist. Betty Fisher Assistant Typist Gladys Smith
Under the editorship of Russel. Murray, the College paper has been very successful in the third year of its existence. It has presented College news in a very interesting and enjoyable manner. In addition to the news, there have been many enlightening editorials written on College, local, and national affairs. The "scandal department" was evidently enlarged, and as a result, the editor's existence was rather perilous!

One of the biggest improvements in the paper was the new method of printing it. During the last part of the year the paper was mimeographed, while formerly it was printed on the "ditto" machine.

The paper had a larger subscription this year than ever before. (Could it have been concerned with the scandal department?) Whatever the cause, we're looking for a bigger and better paper next year.

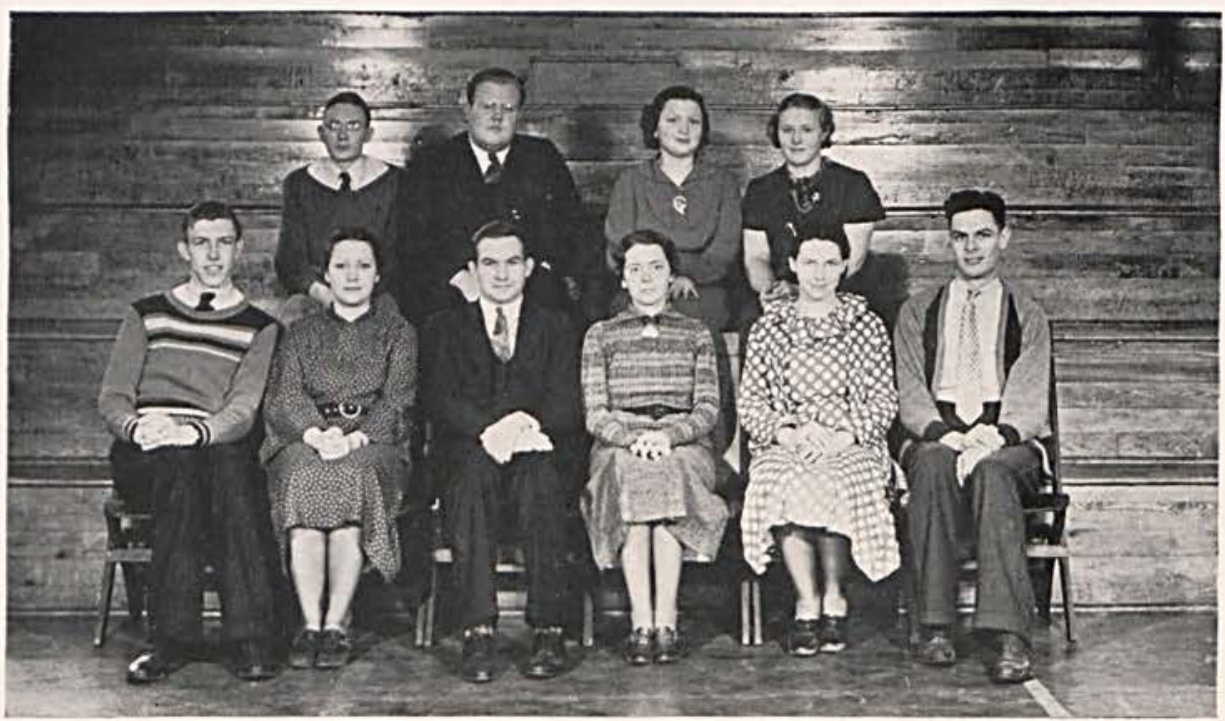

Page Thirty-four
GROUP

First Row: Hartman, Ritenour, Murray, $\mathrm{F}$ is h e $\mathrm{r}$. Smith, Anderson.

Second Row: Buehler, Trubee, Olinger, May. 


\section{INTERCOLLEGIATE DEBATE}

Cedarville College in its fifth year of intercollegiate debating was represented by eight students: Affirmative-Ruth Kimble, John Tobias, James Anderson, and Joseph West. Negative-Justin Hartman, Harold Shaw, Harry Wallace, and Donald Burkert. Mrs. J. W. Ault acted as debate coach. The question for debate was, Resolved: That Congress should be empowered to override by a twothirds vote of both houses decisions of the Supreme Court declaring actions of Congress unconstitutional.

There were debates scheduled for the early part of the season, but because of the inclement weather, they were postponed.

Thus it happened that the Cedarville teams entered the North Manchester Convention without any previous experience. Upon examining our schedule after registering in North Manchester, we found that we were to debate all large colleges and universities since Cedarville, because of previous records, is entered in Class A. Nothing daunted by the size of the universities represented by their opponents, the Cedarville teams put forth their best efforts and as a result of the debates scheduled. Cedarville defeated Chicago University, North Manchester, and Evansville.

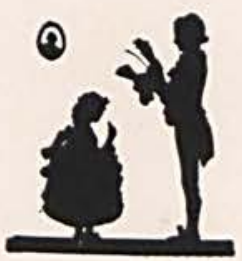

After the Convention, Cedarville met Rio Grande with whom we divided the victory - the Affirmative losing and the Negative winning. The season closed with two non-decision debates with Dayton University.

This year the squad loses Donald Burkert and Joseph West. With six members remaining, we are hoping for another successful year during 1936-'37.

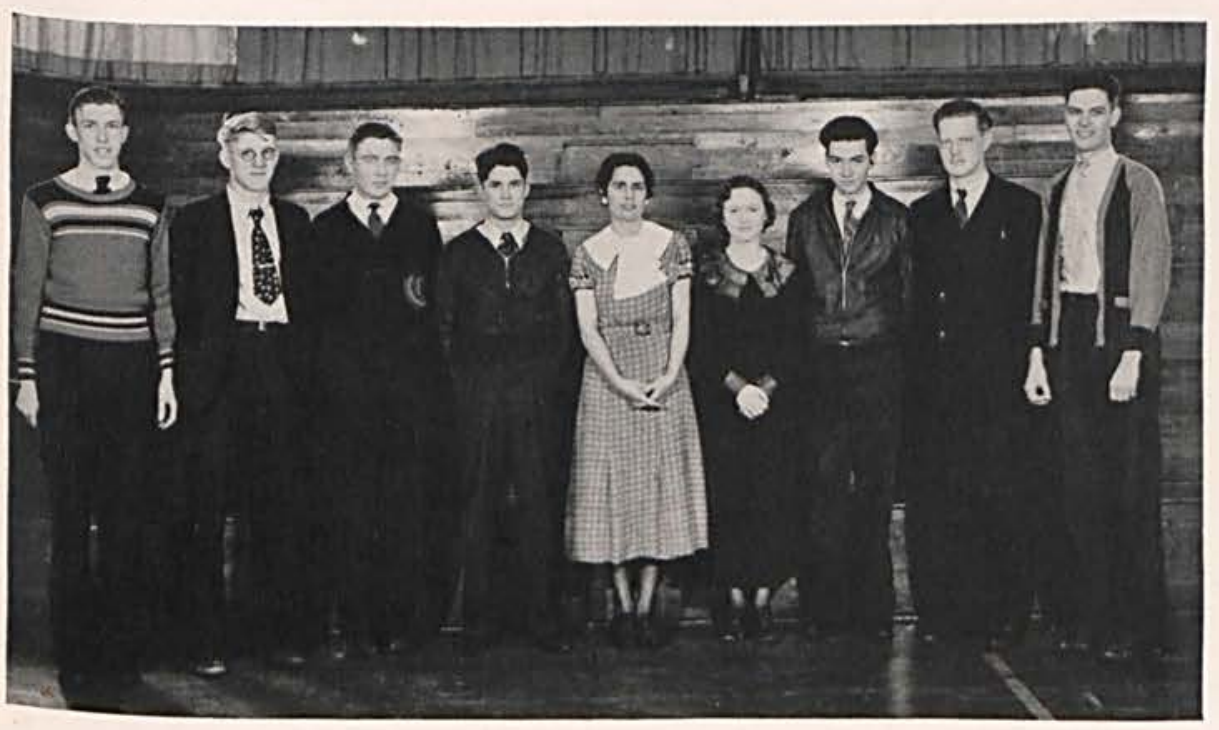

DEBATE SQUAD

Justin Hartman. Harold Shaw, Harry Wallace, Don ald Burkert, Mrs. J. W Ault, Ruth Kimble, John Tobias, Joseph West, James Anderson. 


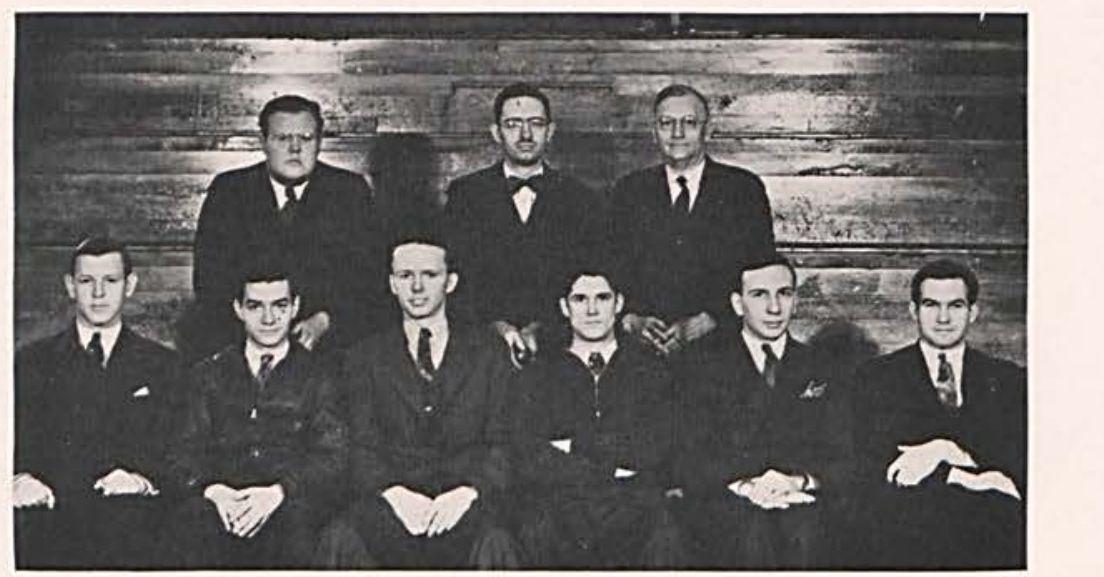

\author{
Y. M. C. A. \\ First Row: Richards, Tobias, Corry, \\ Burkert, Angell, Murray. \\ Second Row: Trubee, Kuerhman, \\ Steele.
}

Every Wednesday, the Y. M. C. A. meets at the chapel hour. Many varied programs were presented this year by our program chairman, Eugene Corry. We were entertained by speakers, musical, chemistry, and physics programs. All of these were instructive as well as enjoyable.

The Y. M. entertained the College with the Hallowe'en party this year.

The College Minstrel given on the twenty-sixth of March was a great success. The Minstrel being built around the naval theme, the boys sailed away on a trip on the good ship U. S. S. Cedrus. Ad- miral Donald Burkert, disproving some of the songs, sailed with his crew and governed the actions of the end men. The crew returned to the tune of "Shipmates Forever." The voyage was a success, the minstrel was a success, and the $Y$. treasury was a success.

Compulsory attendance at $Y$. has been removed. This new plan has proved satisfactory and also has given a better attitude towards the meetings.

We feel that the $Y$. as in the past has proved itself a worthwhile organization and we are expecting a like organization next year.

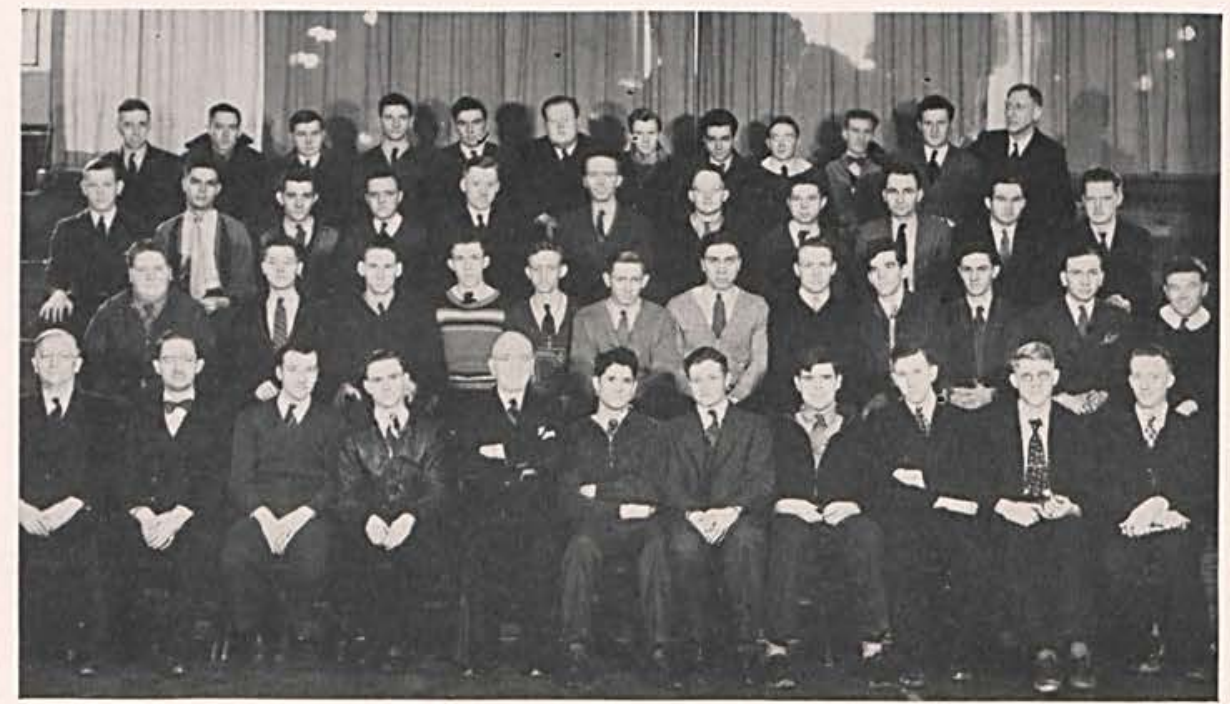

First Row: Steele, Kuerh. mann, Reed, Sisson, Mc. Chesney, Burkert, Michael, Prescott, Garlough, Shaw, Hoke.

Second Row: Burk, Lott, Thomas, Hartman, Sinks, MeDonald, Smith, Johnson, Thompson, Shaw, Angell.

Third Row: Richards, Anderson, Heifner, Linton, Sanderson, Corry, Beals, Flory, Ault, Murray, West.

Fourth Row: McLaughlin, Gi b s on. Murray, Ross, Grube, Trubee, Waddle, Tobias, Buehler, Cunimings, Swaim, Jurkat. 


\section{Y. W. C. A.}

\section{CABINET}

First Row: Johnston, Ritenour, Work. Wham, Fisher, Kimble.

Second Row: Brill, K. Miller, Ander. son, Brill, McKnight.

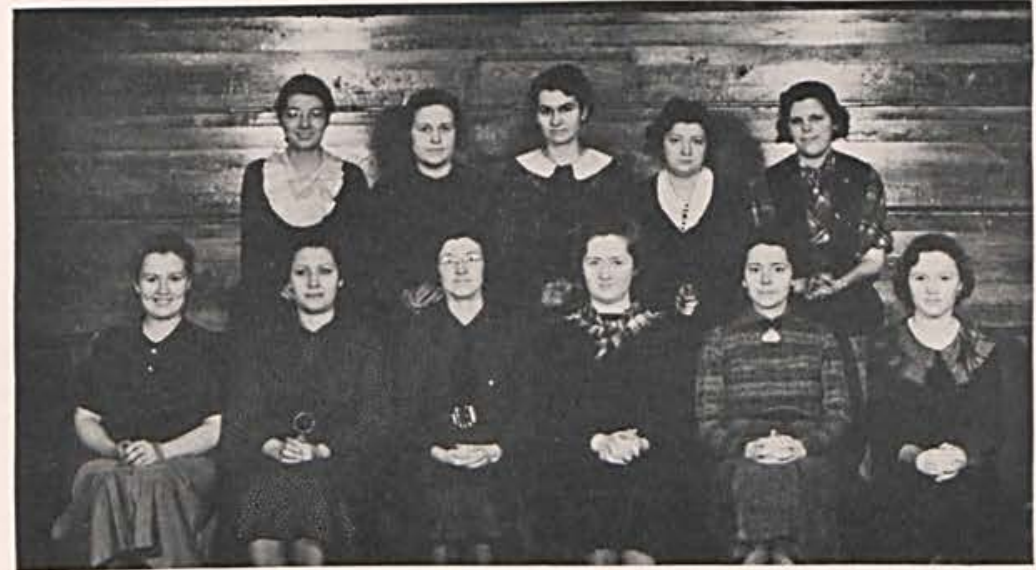

followed many weeks of unexpected yifts and mystery which were climaxed at the Christmas party at the home of Miss Mary Williamson. Before the party, the girls sang Christmas carols before the home of the beloved Mrs. Steele who has been ill for the past months.

Election of officers for the next year resulted in the following: President, Ruth Kimble; Vice President, Dorothy Anderson; Secretary-treasurer, Mary Johnston.

The year ended in the Mother-Daughter Banquet which was held at the College Gymnasium on Friday, May 15.

In October, the girls drew their secret pals. There

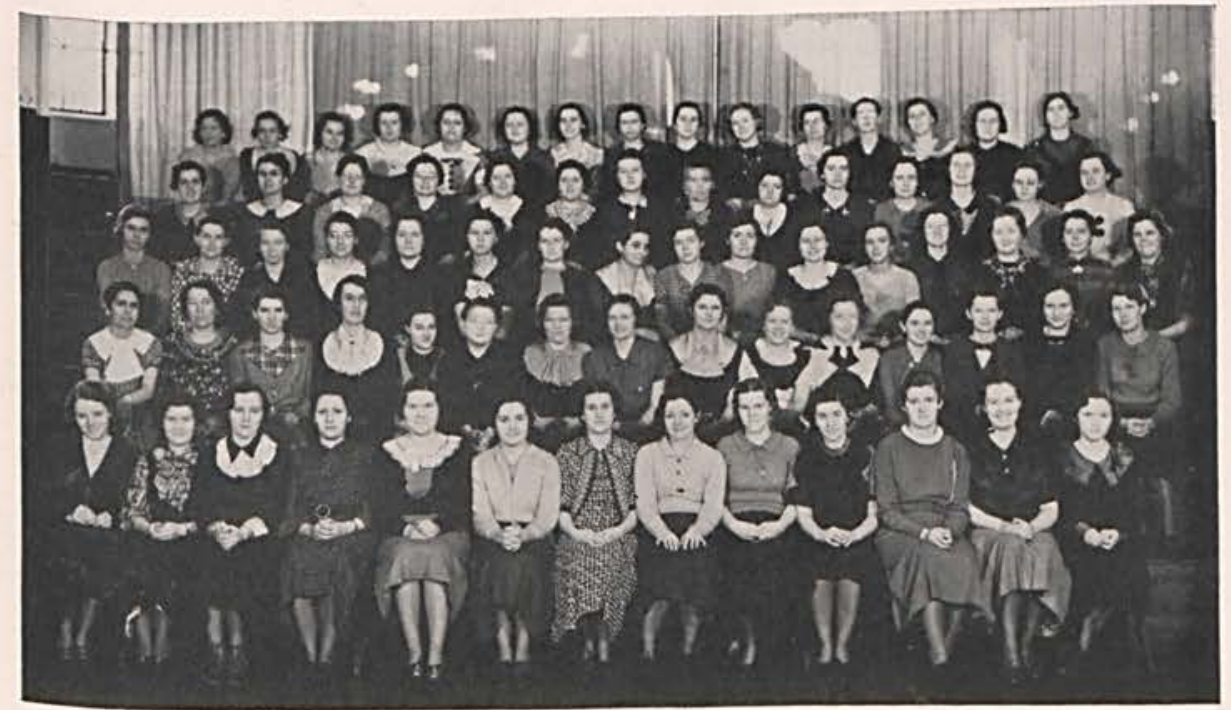

First Row: Porter, Hageman, Miller, Ritenour, Bry ant, Jacobs, Hughes, Seamon, Long, Graves, Batdorf, Johnston, Kimble.

Second Row: Ault, He'ntz. MeDorman, Mossman, Tobias, Kimble, Cool e y Frame, Waddie, Tindall, Wrame, Waddie, Tindall, M. Smith, L. Smith.

Third Row: Basore, G. Smith, Corry, Brill, Wones, Pierce, Williams. Collins, Tipton, Fetcher. McCle lan, Grimes, Work, Wham,
Fisher, McKnight.

Fourth Row: Holland, Anderson, Beard, Bumgarner. Kendig, Kendig, $\mathrm{S}$ h u $\mathrm{m} \mathrm{p}$, Lott, Brill, Cline, Alexander, Cres w e 11, Allison, Clouser.

Fifth Row: Post, Nelson. Jones, McHenry, Richards. Olinger, Ackerman, Waddle, Labig. May, McKenzie, McCallister, Shaw, Miller, Creswell. 


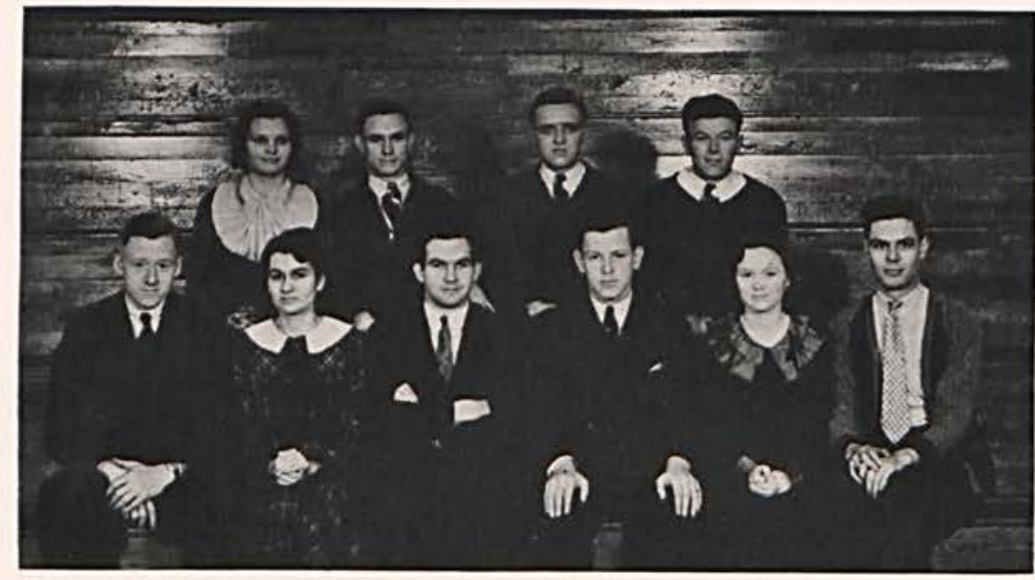

\section{LITERARY SOCIETY}

\section{OFFICERS}

First Row: Sanderson, Anderson, Murray, Richards, Kimble, Anderson.

Second Row: Jones, Sisson, Linton, Gillespie.

The Philosophic Literary Society is one of the oldest social groups connected with our College. For years this society has been holding bi-weekly meetings in the basement of the Carnegie Library.

This year we have had several well-attended meetings. Programs that were very interesting and instructive were given by college students and also by guest artists. Some of our interesting guest speakers have been: Mr. King Creswell, a World War veteran; Bob Confarr, a commercial artist from Selma; and Mrs. Paul Orr, who told of her western trip.

A hay ride was one of the big features of the year. About fifty members travelled to Xenia, Yellow Springs, and Springfield. A feed of hamburgers was much enjoyed by the chilled riders. Another outside meeting will be held late in the spring.

The purposes of this group are to get college students better acquainted with one another, to promote public speaking and participation in campus affairs, and to inform students on the problems of the day.

We are looking forward to another year of social activities and discussion during 1936 and ' 37 .

First Row: Sanderson, Anderson, Murray, Miller. Linton. Hartman, Batdorf, Brill, Kimble, Kimble.

Second Row: Murray, Burkert, Thomas. Gibsoy, Burk ert, Thomas. Gibson, Hageman, McCallister, B rill. Clous e r, Cooley, Long, Graves.

Third Row: Anderson, Sisson, Reed, Tindall, Michael. Hughes, Jacobs, Jones, Nel son, West, Bumgarner.

Fourth Row: Trubee, Reed. Pierce, W o ne s, Gillespie, Post, Berk, Richards.

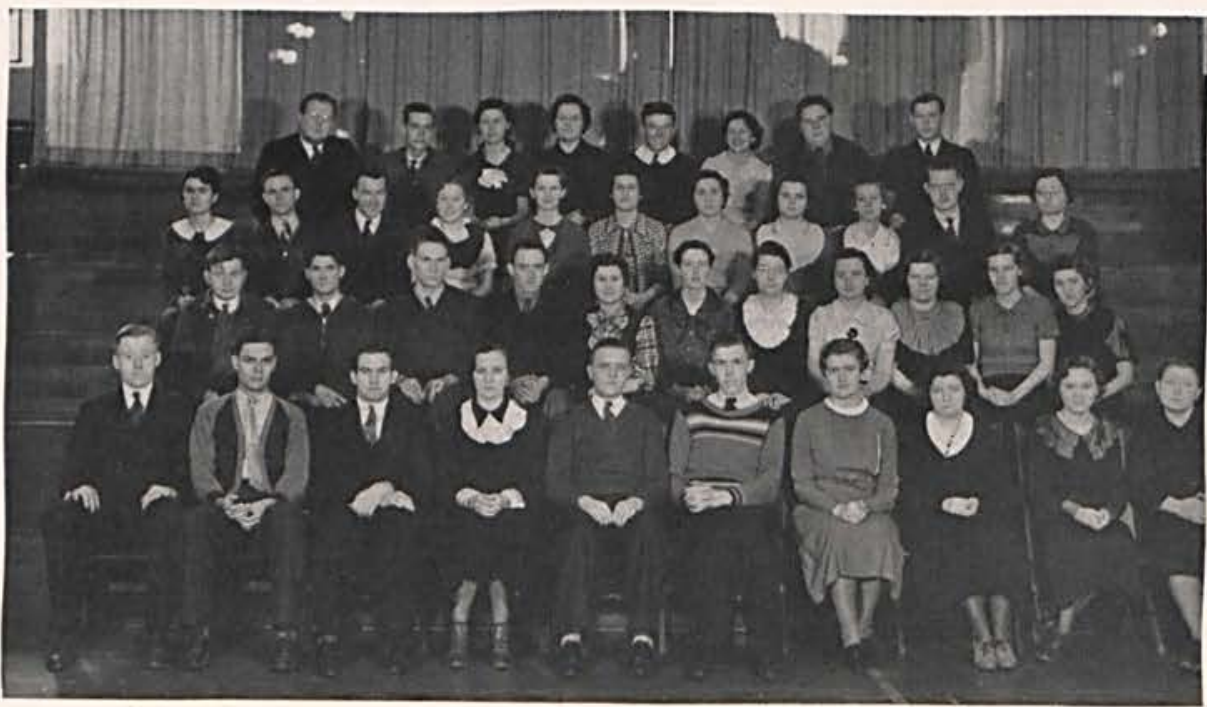




\section{DRAMATIC CLUB}

\section{OFFICER;}

First Row: May, Hartman, Heintz Anderson, Brill.

Second Row: Reed, West, Ritenour, Porter.

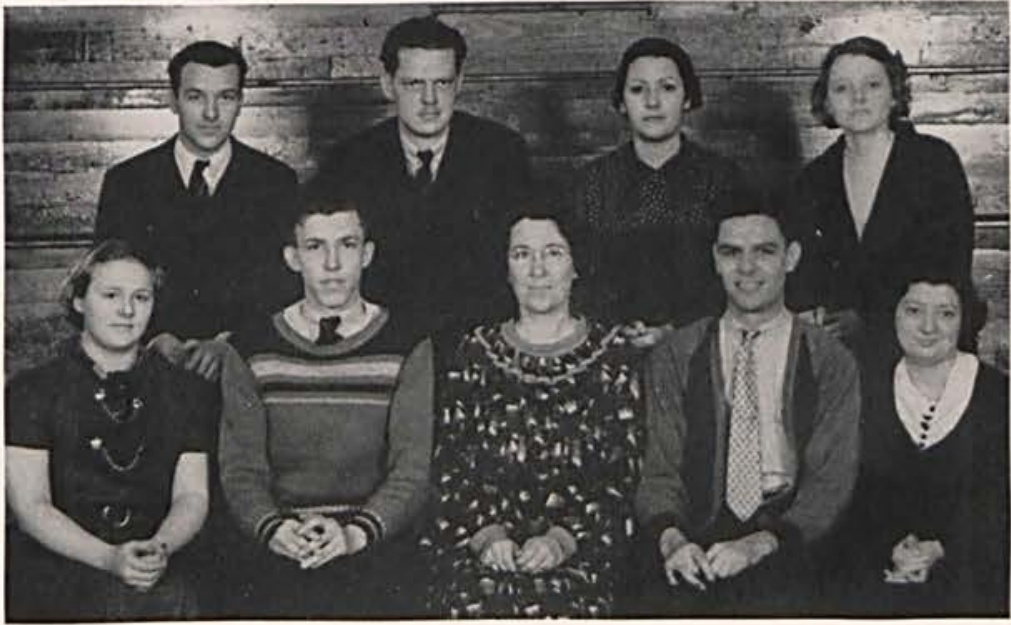

The Dramatic Club of Cedarville College is now closing its second year of campus activities under the direction of Mrs. Louise Heintz, head of the English department. Under the able direction of our officers, this Club has done much to forward the purposes for which it was established which are: To give to college students practical experience in acting, and in directing and managing theatrical productions and to give them a better appreciation of modern drama.

The Club meets on the first and third Monday nights of each month, producing at each meeting a one-act play, directed and managed by the Club members. Thus far, the Club has presented the following plays: "Between Trains," "Fine Gold," "Alice's Blue Gown," "The Whole Truth," "Sauce for the Goslings," "Thursday Evening," and "Brain Storm." These plays have been presented before local groups.

The Dramatic Club has several projects in view, such as obtaining a curtain and footlights and making scenery for our stage. We are hoping to secure a curtain, with the aid of our friends, before the end of the year.

That the Club in the future shall prove as interesting an activity as it has for the past two years is the earnest desire of every member of the Dramatic Club.

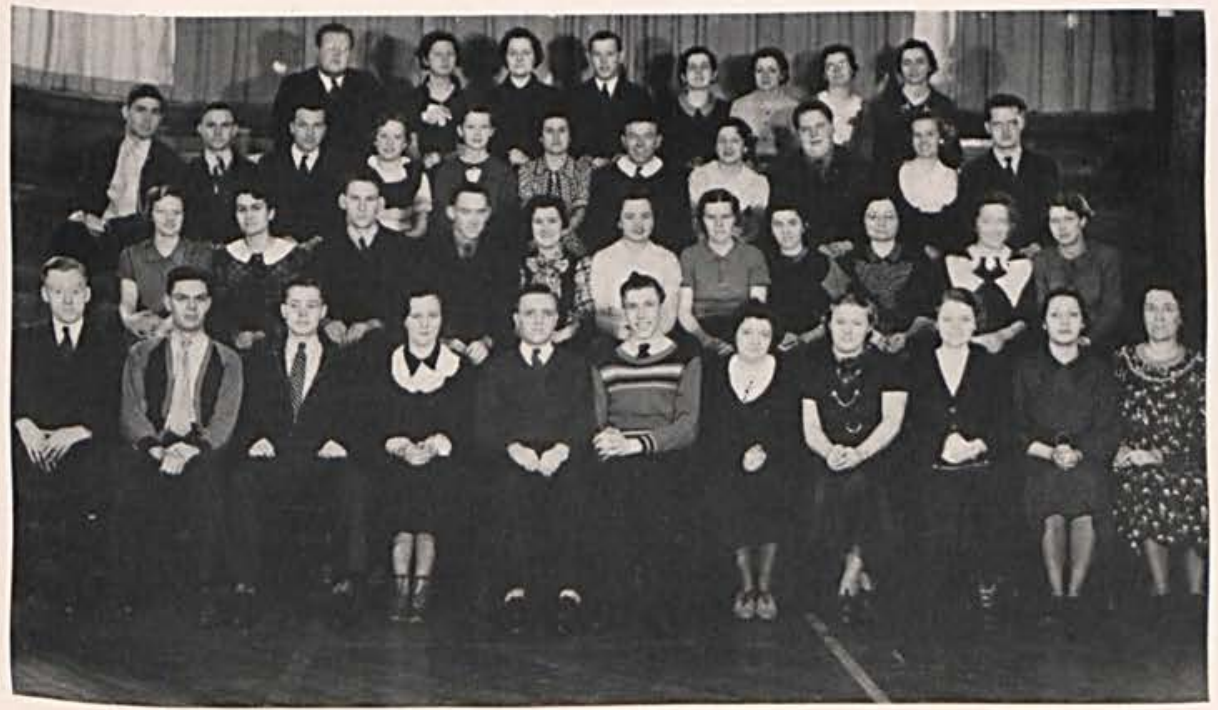

First Row: Sanderson, Ande rs o n, Lott, H. Miller, Manton, Hartman, B rill. Heintz.

Second Row: Frame, An. derson. Thomas, Gibson, Hageman, Clouser, Long, Graves, Bumgarner, Watkins, Smith.

Third Row: Faulk, Sisson, $R$ e ed, Tindall, Michae: Hughes, Gillespie, Post. Berk. Nelson, West.

Fourth Row: Trubee, Piere. Wones, Richards, Holland, seamon, Mckenzie, Kline. 


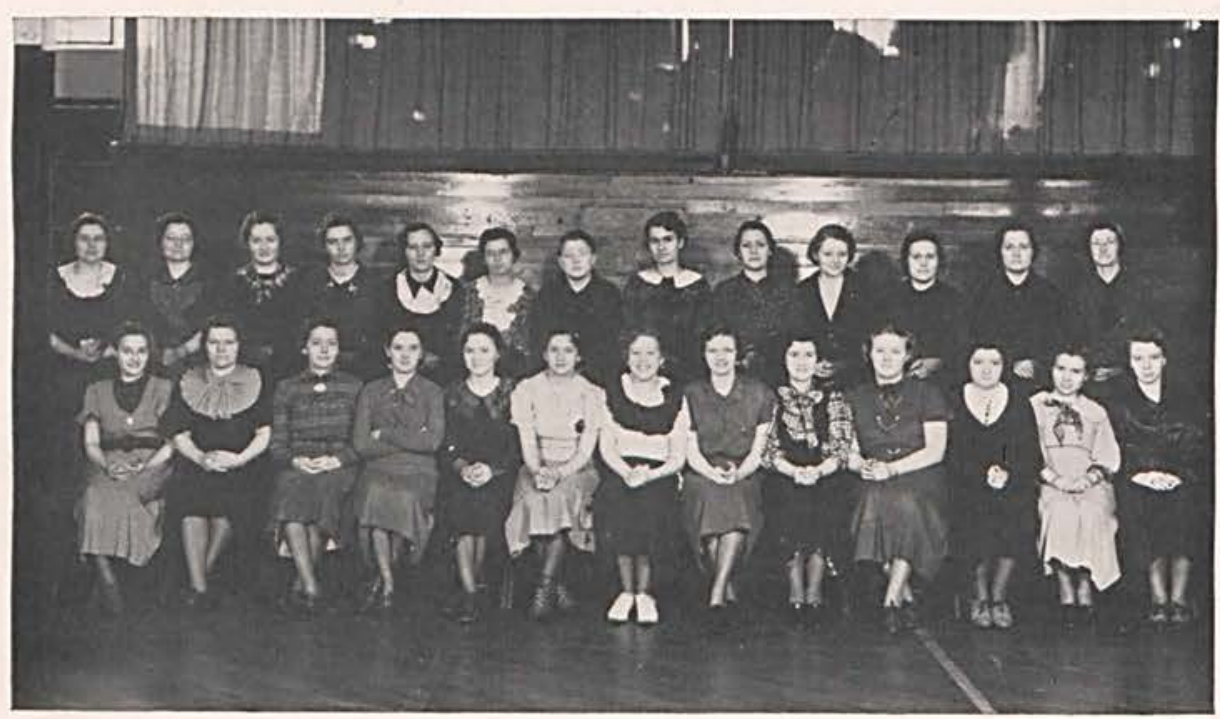

\section{GIRLS' GLEE}

GLEE CLUB

First Row: Tobias, Cooley, $\mathrm{F}$ i s h e r, Nelson, Kimble, Post, Tindall, Frame, Hag.

eman, May, Brill, Flory, Cory.

Second Row: McClellan, Bumgarner, Wham, Cline, H. Miller, McKenzie, Kim $\mathrm{b}$ i e, Anderson, Ritenour. Porter, K. Miller, Wones, Mrs. Work.

The Girls' Glee Club has accomplished many worthwhile things during this year under the direction of Mrs. Margaret J. Work. In the fall, the Glee Club, assisted by the Girls' Quartette, broadcasted over Station WHIO in Dayton. During the year we have given religious programs at the O. S. and S. O. Home in Xenia, at the Methodist Church in Piqua, at the United Presbyterian Church in $\mathrm{Xe}$ nia, and in Clifton. We are planning to end our year's work during Commencement Week and in the Spring Recital.

In addition to their group activities, each member has derived a greater appreciation of good music, and a fine spirit of cooperation during the school year.

The girls of the Glee Club wish to thank Mrs. Work for her work and her patience. We are also grateful to Dr. Mac Chesney, to the drivers of the cars, and to all who made this year possible.

\section{ORANGE AND BLUE SERENADERS}

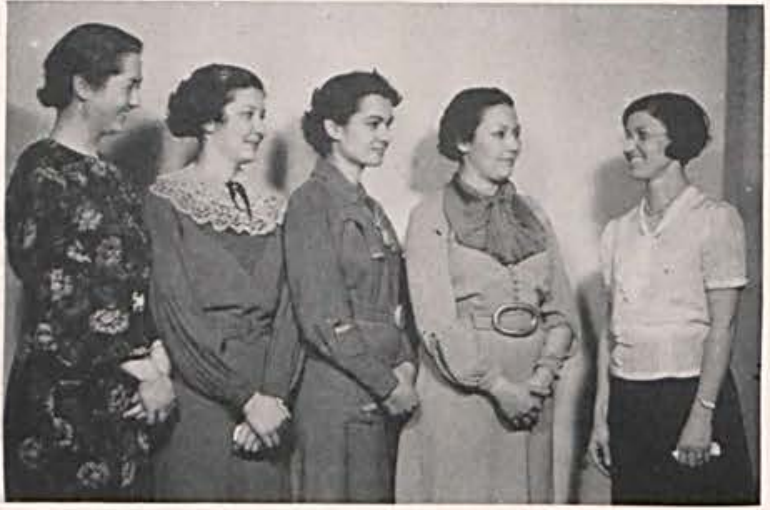

This year the Girls' Quartette presented programs at various club meetings in Cedarville and has accompanied the Glee Club to Piqua, Xenia, and Dayton. The girls also travelled into Kentucky for a week-end where they gave several programs.

Wham, Robe, Anderson, Ritenour, Mrs. Work. 


\section{COLLEGE CHORUS}

First Row: Corry, Frame,

Wham, Fisher, M. Nelson, H. Nelson, Porter, Anderson, Ritenour, Brili, Miller. Hageman, Wones.

Second Row: Work, Reed, Richards, Andrews, Sisson. Burkert, Burk, Gibs o n, Sanderson, Anderson, Foulk, West, Walker, Lott.

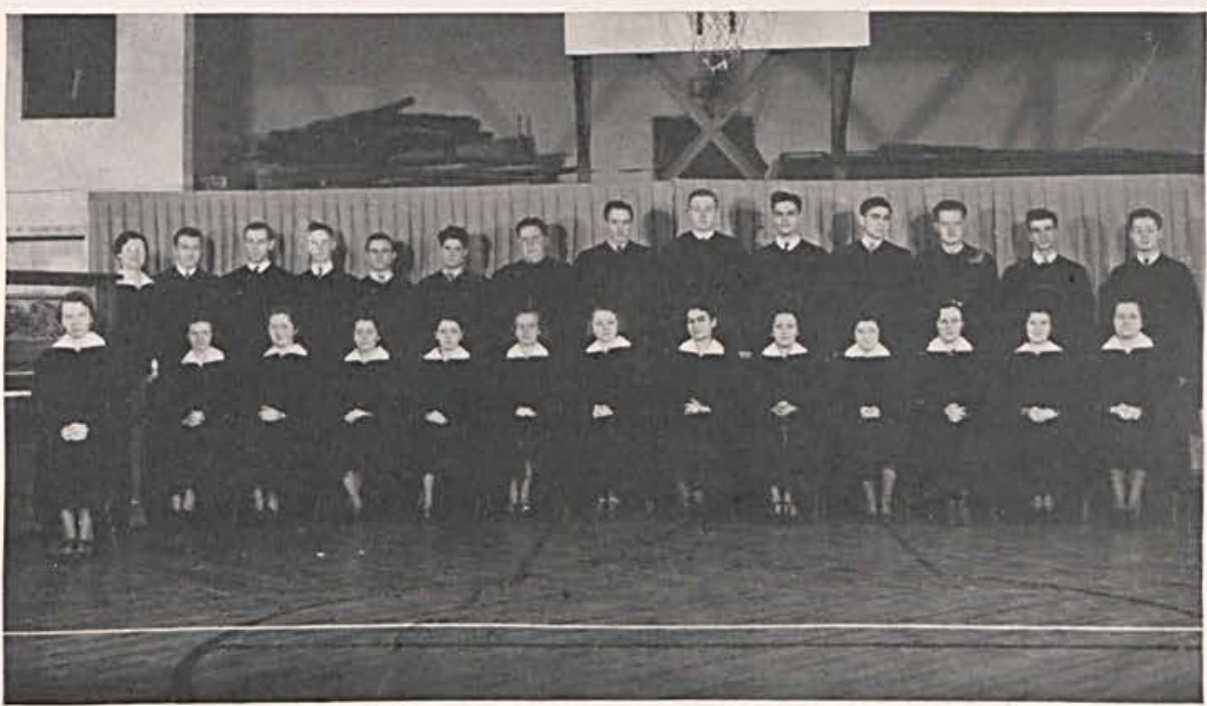

The mixed Chorus has been a prominent organization in the music department of the College. It offers excellent training in music to both men and women. Every Monday and Wednesday evening it meets for rehearsal, under the talented direction of Mrs. Margaret J. Work, professor of music.

The Chorus has appeared at many college functions during the year. Among which were the Wilberforce International Music Festival, the Peace Program, the Men's and Women's Bible Reading
Contests and Baccalaureate. Besides, the Chorus has made its appearance in the two music recitals during the year. The Chorus is fully vested and has given Choral programs in different churches during the year.

Any college student is eligible to try out for membership in the mixed chorus. This year the chorus consists of twenty-five members with Miss Dorotha Corry serving as Accompanist.

\section{MALE QUARTETTE}

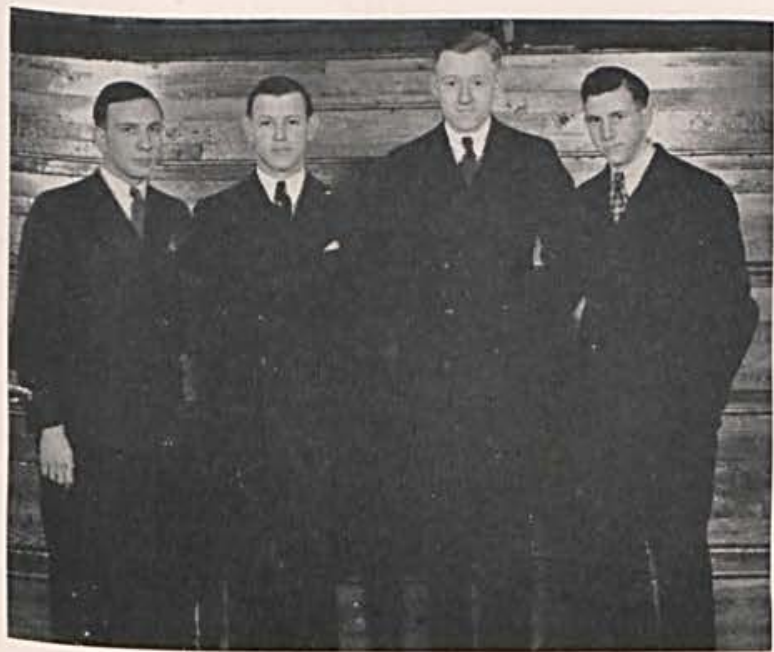

This year after approximately ten performances in Cedarville, Piqua, Bellbrook, Xenia, Carlisle, and Bowersville, the quartette, accompanied by Mrs. Work and Anna Jane Wham, were sent on a tour of Southern Illinois. Later the boys accompanied Mrs. Work to Kentucky. The quartette feels that its fine success is due to two things: work and Work. 


\section{COLLEGE BOARDING CLUB}

Of all the groups on the campus, the College Boarding Club enjoys the unique distinction of being the only one that, even though lacking organization and executive officers of any kind, meets in regular session twice daily each day that college is in session.

Each September sees a few of the old faithfuls and many new faces gathered around the table. At first there is a sort of nervous tension and no one is quite at ease, but that soon is eliminated, and it is not long until all are like one happy family. They soon learn each others' likes and dislikes - spinach, tomatoes, sweet potatoes, etc.-and the newcomers learn to call for "goo" when they want spread.
Table conversation is widely varied, politics, professors, movies, feeds, this girl, and that fellow and so on.

Mrs. Morton is the efficient manager of the Boarding Club, and she and Mrs. Stuckey certainly know how to satisfy healthy young appetites. We are grateful to them for catering to the special likes of our members at certain times.

This organization is one of the best on the campus for the furthering of friendship and social activity. Everyone who has spent a year at the boarding club feels that he knows his fellow boarders better than he would have otherwise.
BOARDING CLUB

First Row: Faulk, Gibson, l.inton, Reed, Batdorf, McCleli a n, Wham, Fisher, Wones, Pierce, Basore.

Second Row: Floyd, Long, Sinks, Trubee, Wallace.

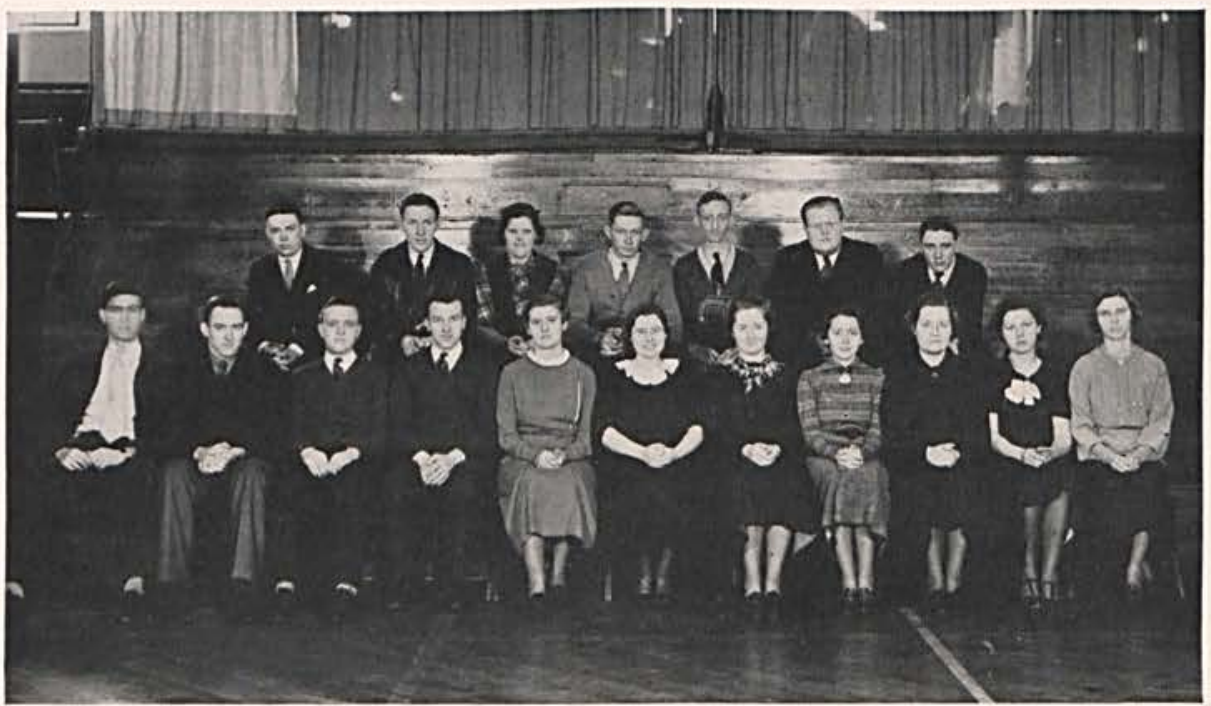




\section{MONKS’ CLUB}

The present Cedarville College Gospel Team was organized as the Monks' Club in the fall of 1933. It was organized by a group of ministerial students and others in the college, who wished to express themselves in Christian Service. It pays no heed to denominational lines, as students of various denominations work harmoniously in it. Of the charter members, six are in school this year; two of them in Seminary and four in College. Two will be here next year. Other members have been added from time to time.

The Gospel Team has given services in many churches within seventy-five miles of Cedarville. Besides churches it has given services in London Prison Farm, Old Folks' Home, Good Will Indus- tries, and such places. This has been a splendid experience and training for the members of the team, and has doubtless been a help to the places served.

Both the Captain and the Business Manager have been filling regular charges this winter.

The Team will need recruits next year to keep it giving the best of service to those who need it. We trust that there will be those who will join it and keep it going forward in useful service.

$$
\begin{aligned}
& \text { Captain_Paul McLaughlin } \\
& \text { Business Manager-Paul Angell } \\
& \text { Treasurer-Franklin L. Trubee }
\end{aligned}
$$

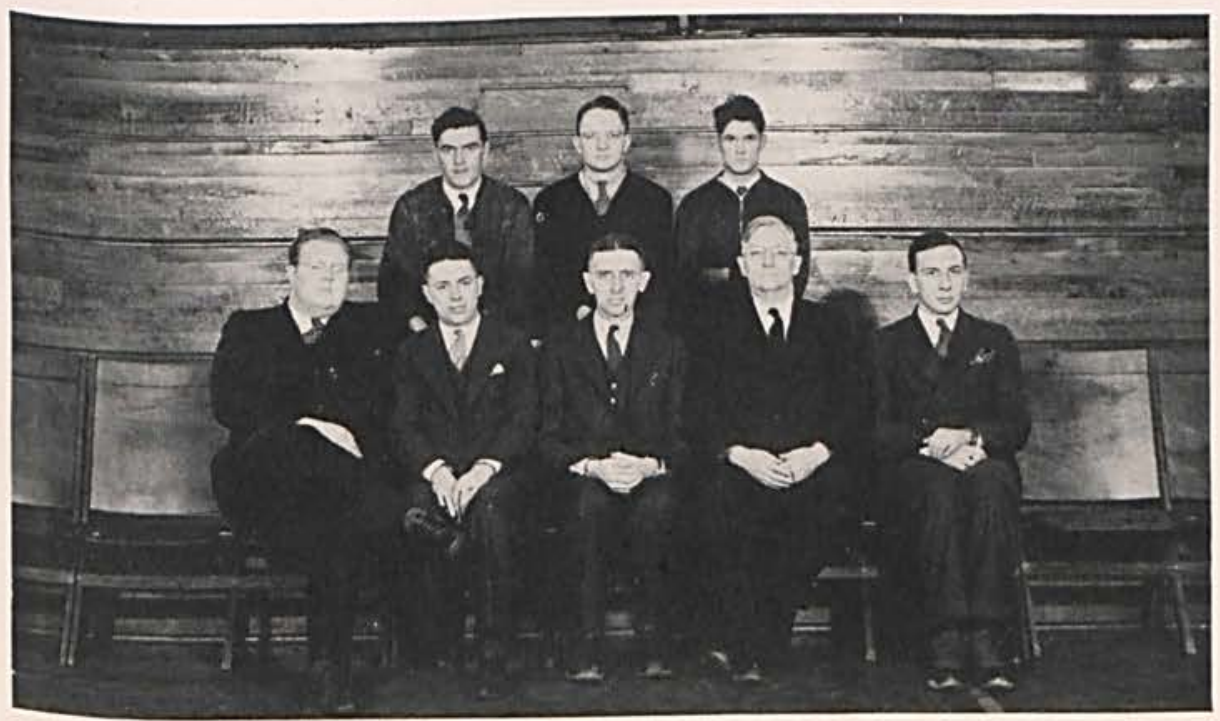

MONK'S CLUB

First Row: Trubee, Floyd, McLaughlin, Steele, Angell.

Second Row: Grube, Beals, Burkert. 


\section{DELTA KAPPA SIGMA}

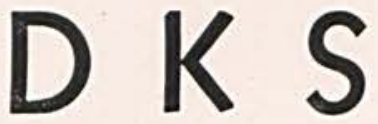

This year the Delta Kappa Sigma Fraternity underwent a complete reorganization and is thriving as a result of it. This was accomplished under the leadership of the president, John Richards, as he was the only active member left in the college. In the fall, six pledges were initiated into the fraternity with a great deal of trial and tribulation with the help of some inactive members.

The major problem facing the group this year was to find a suitable house. Finally a three-room apartment above the bank was rented. It consists of a large recreation room, and living, rooming, and sleeping facilities for roomers. There is also equipment for cooking in the kitchenette.

In the spring, seven more pledges were initiated into the fraternity. After serving on pledge duty for six weeks, they came to "Hell Week." This time was quite amusing for the old members, but not quite so funny for the pledges. Outstanding in this initiation, were songs by Sisson and talks by Tomlinson. All of the boys proved quite adept at imitation.

We greatly appreciate the kind cooperation of some of the students of the college and members of the faculty and especially of our advisor, Coach Ault. We are looking forward to a bigger and better fraternity next year.
DELTA KAPPA SIGMA

First Row: Cummings, Tomlinson, Sisson, Swaim, Mc Corkell, Heifner, Gibson.

Second Row: Waddle, Reed, Ross, Michael, Burkert, Tobias, West, Richards.

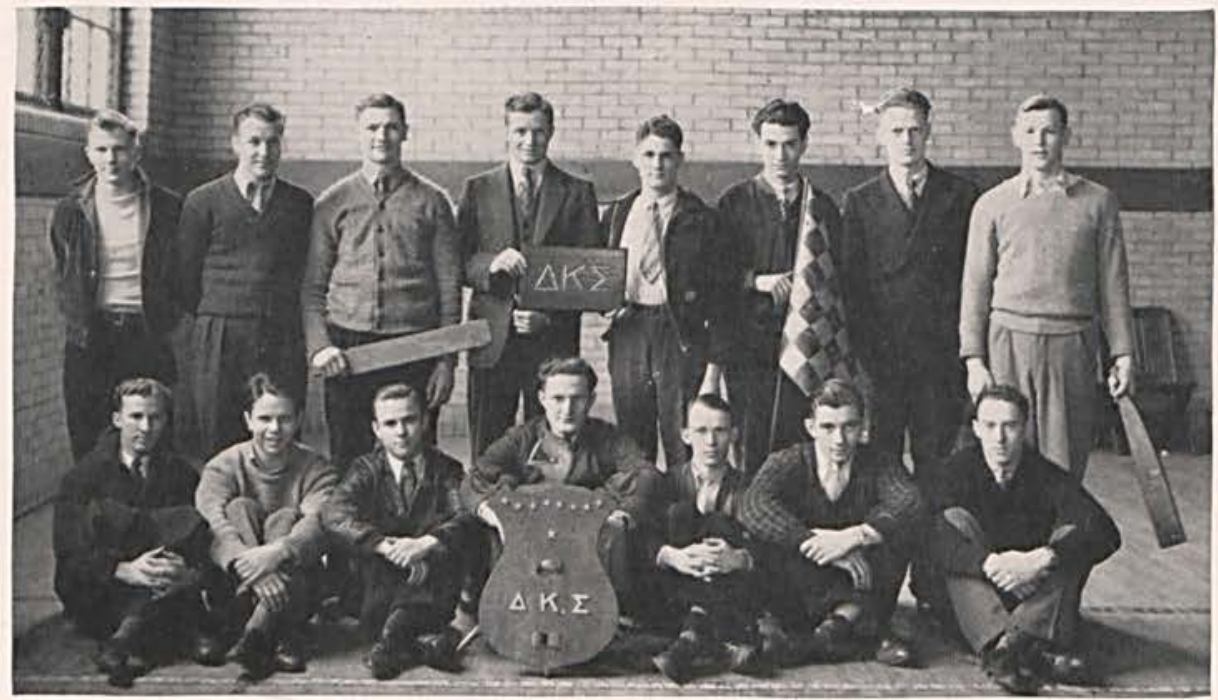




\section{CHI SIGMA PHI}

In recent years, feeling a need of a social organization of girls which will uphold the ideals for which Cedarville College and its students and faculty stand, a movement has been on to initiate such a society. Last year a group of girls met. wrote the framework of a constitution which they thought met these needs, and submitted them to the faculty for approval and revision.

This constitution has been duly approved and recognized by the members of the faculty and the Board of Trustees who have in turn given us a few rules and regulations compounded by them.

We have chosen Mrs. Margaret J. Work as our faculty advisor. The name "Chi Sigma Phi" has been selected. The Greek letters symbolize: CCharacter; S-Service; and P--philos or sisterly love.

This year our group is composed of nine charter members. Next year new members will be pledged according to rules written by the faculty. The following officers were elected: President, Hazel Nelson: Vice President, Christina Jones; SecretaryTreasurer, Gladys Olinger.

In April our group entertained with a theatre party after a covered dish dinner at the home of Dorothy Anderson.

We are hoping that this group in the future will become one of the permanent organizations on the campus and will continue to uphold the ideals of Cedarville College.

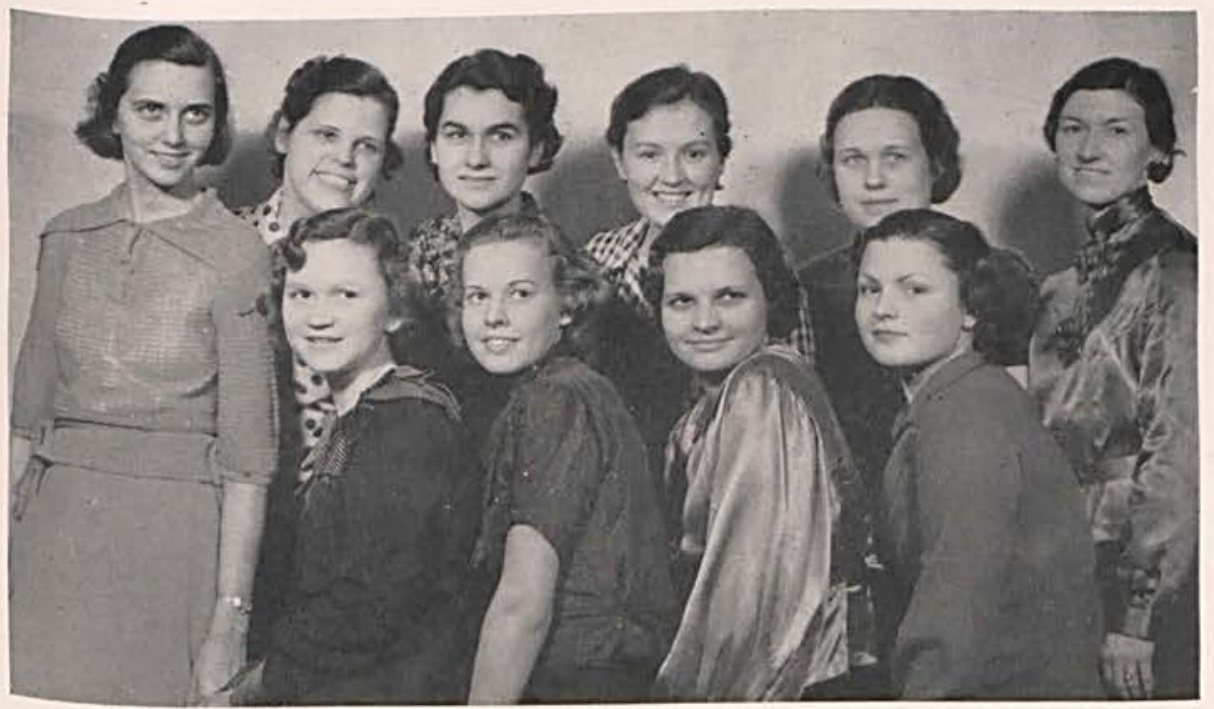

CHI SIGMA PHI

First Row: Kimble, Nelson, Jones, Olinger.

Second Row: Ackerman, McKnight, Anderson, Johns ton, Miller, Mrs. Work. 


\section{LADIES' ADVISORY BOARD}

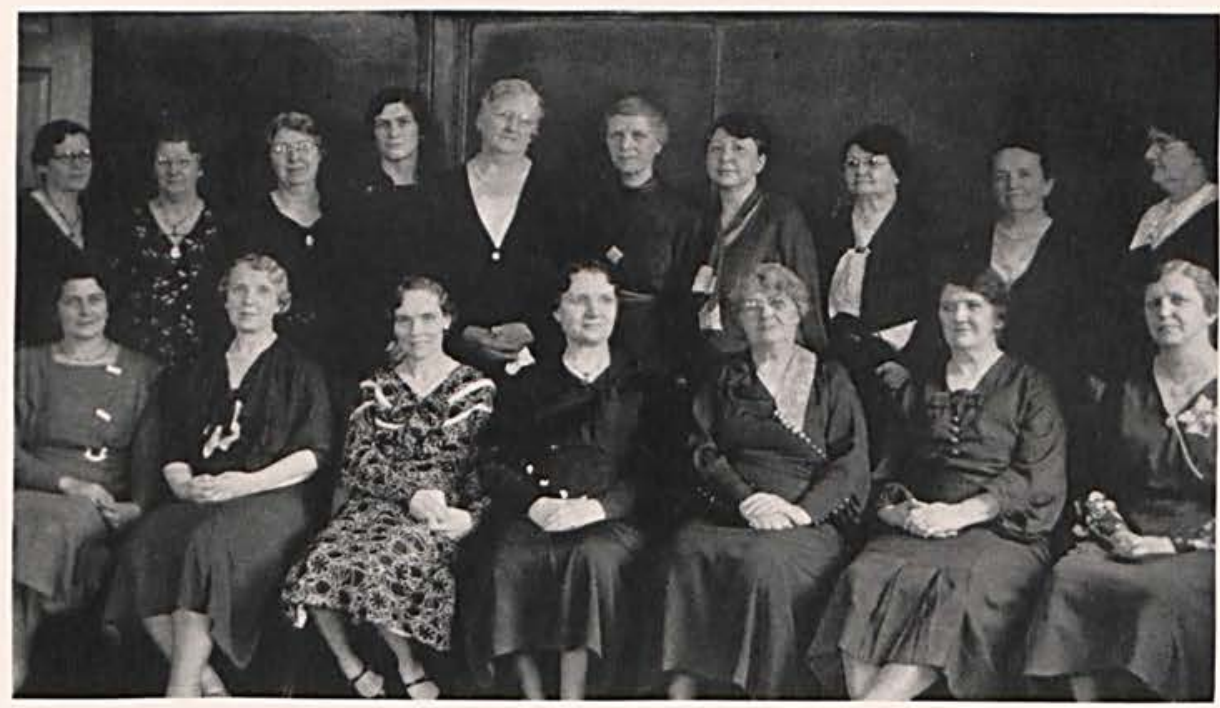

The Ladies' Advisory Board is composed of the faculty wives, wives of the Trustees, and ladies from the churches of Cedarville. The purpose of the organization is to assist the college in any way they can. They serve all the college banquets with the earnings from which they have furnished a well equipped kitchen and dining room. The past year they helped purchase the gowns for the college chorus and at the present time are helping to purchase a curtain for the stage in the gymnasium.
LADIES'ADVISORY BOARD

First Row: Clemans, Iliff, $\mathrm{S}$ t o rmont. McChesney, Oglesbee, Elias, Hartman.

Second Row: Richards, Dobbins, McMillan, Townsley, Johnston, Hostetler, Kuehrmann, Steele, Auld, Wright 


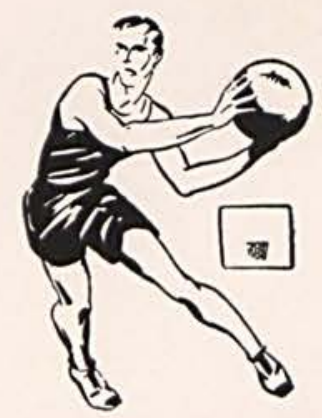

ATHLETICS 
Education that

neglects the physical side

of life falls short. At Cedar-

ville College that function is carried

on by the Physical Education Department. All

of the students of the college are in this department

at some time of their college life. 


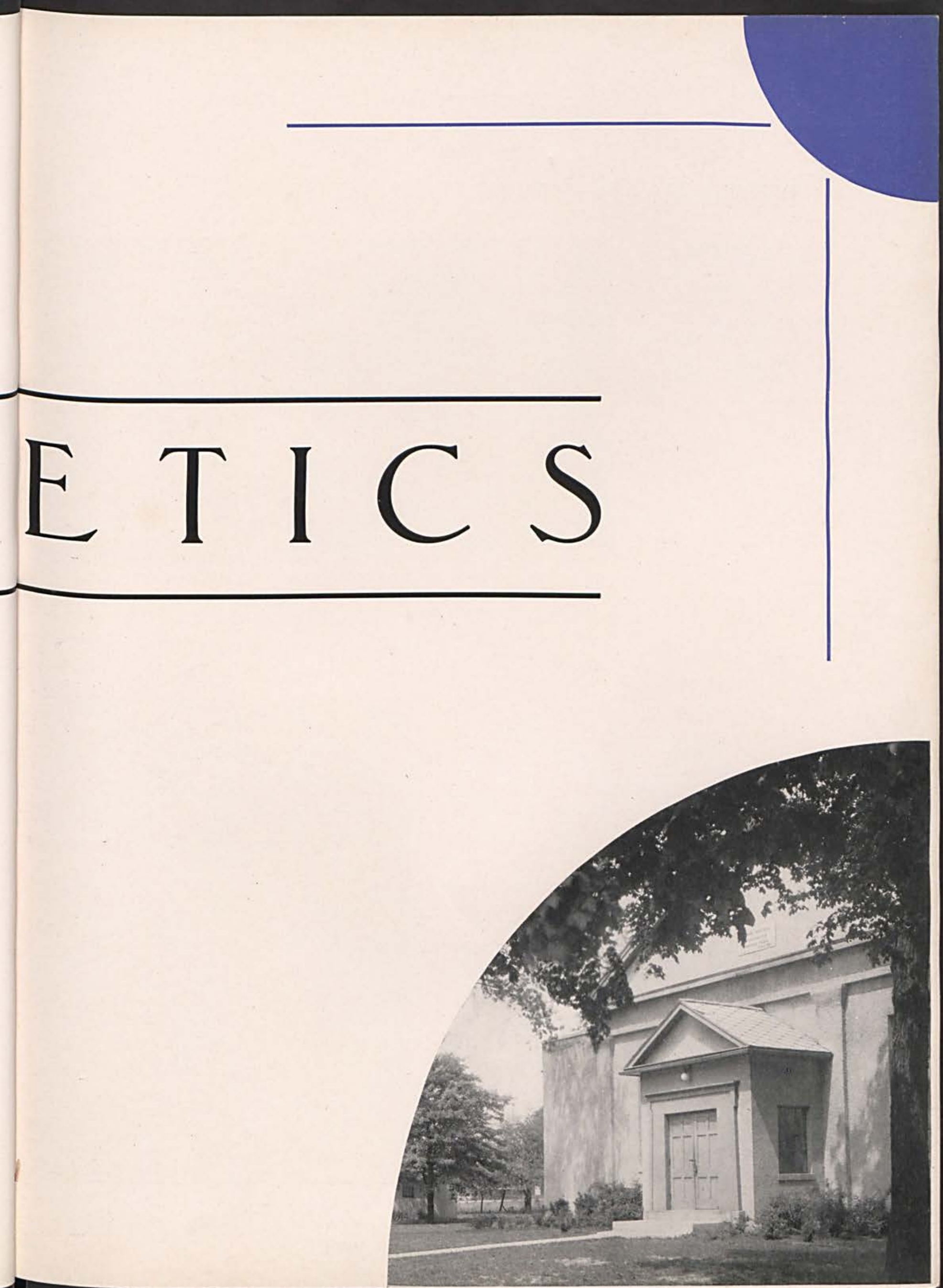




\section{PHYSICAL EDUCATION DEPARTMENT}

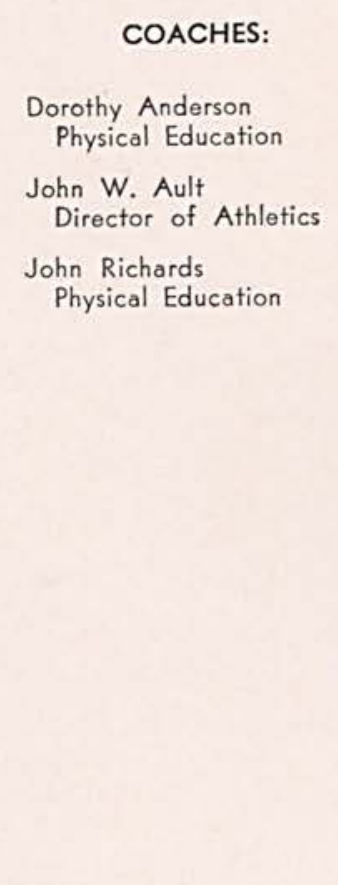

The Physical Education department this year, under the direction of Coach Ault and his able assistants, John Richards and Dorthy Anderson, offered a complete and varied program to meet the needs of the students, at the same time providing interesting competition.

John, with the aid of Coach Ault, conducted a program of calisthenics, softball, basketball, and soccer for the men. The girls of the physical education class found an enthusiastic instructress in Dorthy. The class as a whole carried out a wellbalanced program of basketball, gymnastics, games and hikes.

This year our cheerleaders were Freshman girls. They did work to maintain the school spirit and share the responsibility of a successful year.
CHEER LEADERS

Jacobs

Seamon

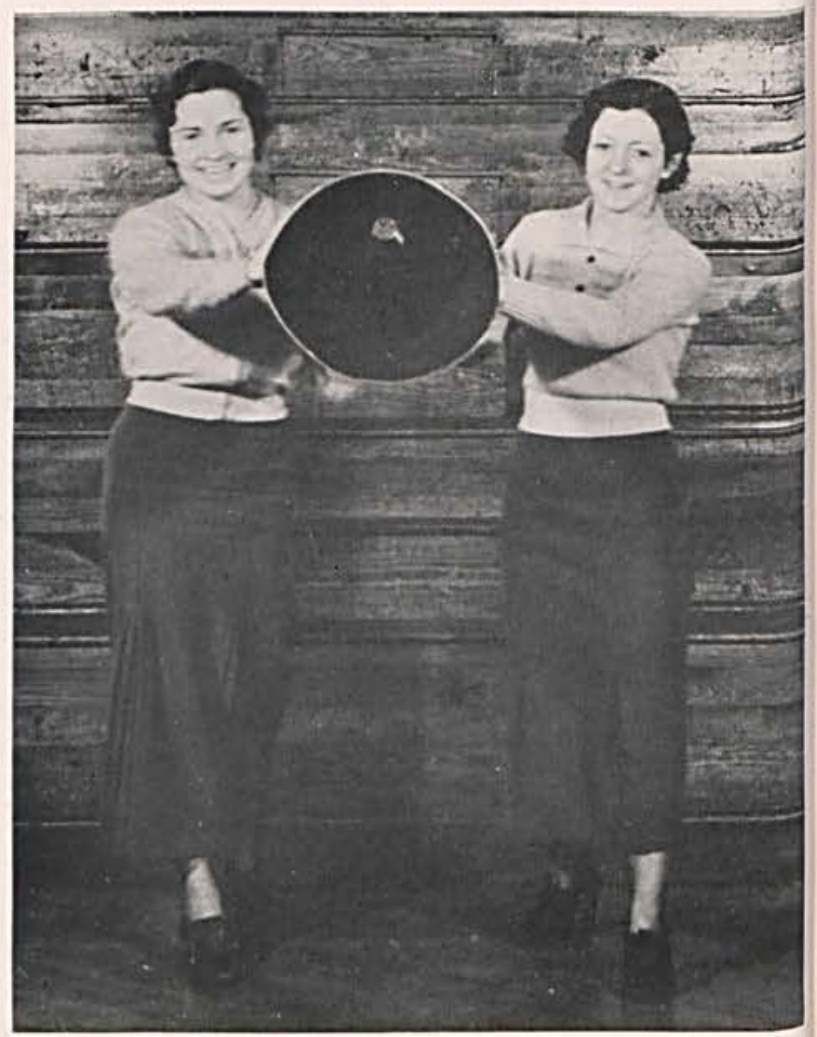




\section{BOYS' PHYSICAL EDUCATION}

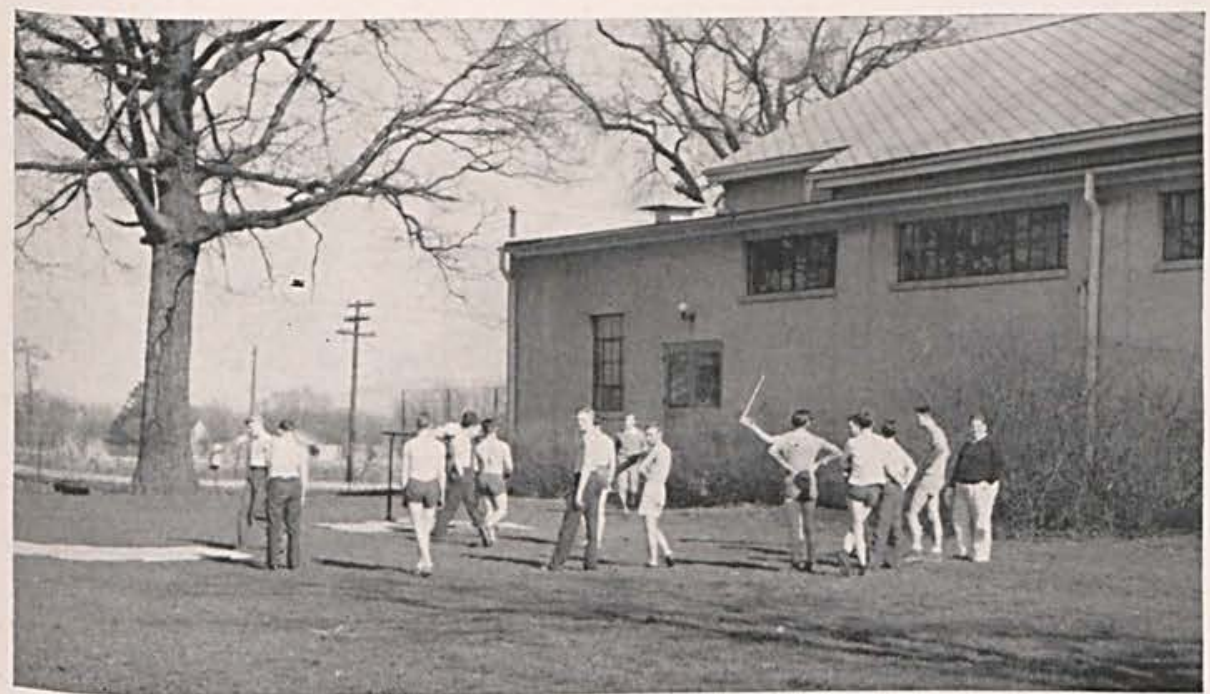

Part of the gym class at the north side of the gymnasium.

KING OF THE BARS

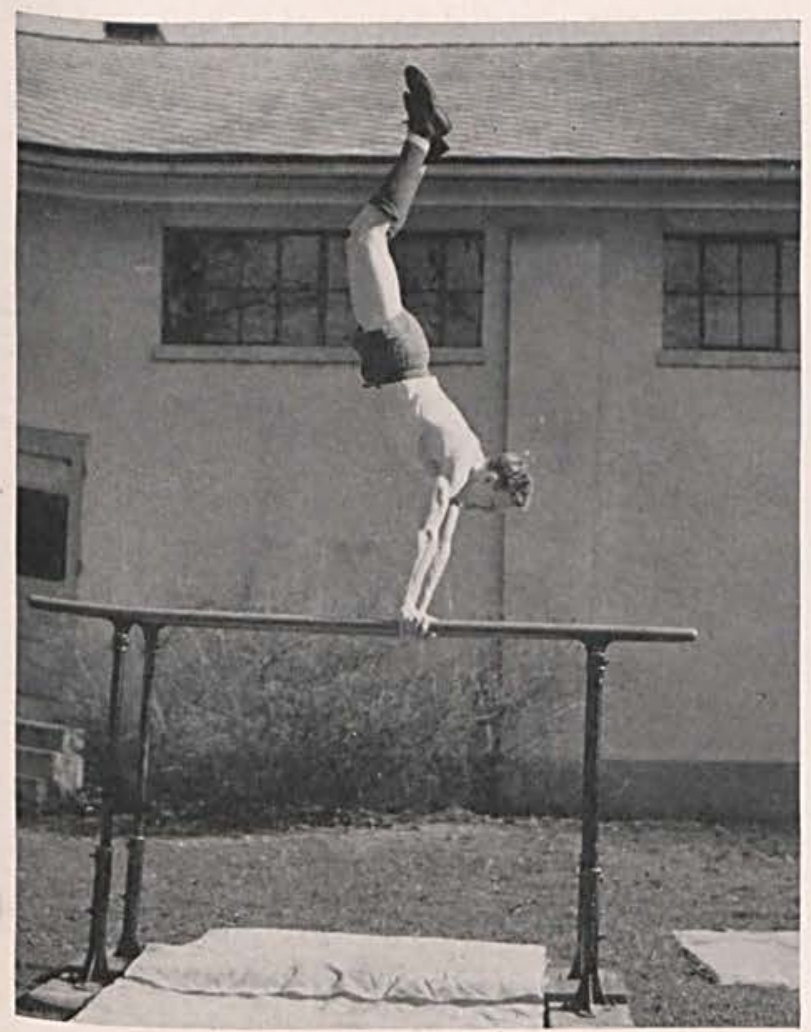

The Physical Education class has had a very interesting and helpful program during the past year under the leadership of John Richards.

In the fall much of the time was spent in playing softball, speedball, and soccer. The teams for ail these games were taken from the class itself. At the beginning of each period throughout the year calisthenics were given to strengthen and to exercise the muscles. In spite of the many stiff necks and sore legs, all agreed that these exercises helped much in building up our bodies.

During the winter months, the class spent its time in volleyball, basketball, tumbling, and acrobatics on the parallel bars.

The class was divided into five teams and a tournament was held among these five in basketball and in volleyball. Some days were given over to field meets. In these meets, the boys from each team went through a certain set of tumbling and acrobatics on the parallel bars, and each one was awarded one, two, or three points according to the perfection of his performance. 


\section{B A S K E T B A L L}

Cedarville College has had a more successful season this year. This can be attributed to two causes: better material and a better school spirit. We feel sure that if this spirit continues in the future as it was this year, the record of the team will reflect the improvement.

\section{SCHEDULE}

Cedarville..... 46 Urbana ...... 28

Cedarville..... 28 Franklin ..... 22

Cedarville..... 37 Defiance ..... 42

Cedarville..... 30 Wilmington ... 23

Cedarville..... 25 Defiance ..... 26

Cedarville..... 27 Bluffton ...... 54

Cedarville..... 32 Wilmington ... 21

Cedarville..... 36 Rio Grande ... 31

Cedarville.....4 41 Franklin .....40

Cedarville..... 35 Bluffton ...... 44
For the first time in years the Cedarville College basketball team has had a successful season. Out of a total of ten games played, our boys were able to capture six, making the very satisfactory record for the season read: Won 6 , lost 4 .

There were several reasons for this exceedingly satisfactory record. In the first place there was a wonderful spirit demonstrated throughout the whole season. Both the team and the school as a whole seemed to feel that this was the year to do something in the way of winning some victories. So they just went out and did it. Furthermore, several Freshman recruits added a great deal of strength to the squad.

No one was lost from the squad by graduation. This makes the prospects for next year all the more rosy.

Letters were awarded to Waddle, Wallace, Ross. Swaim, Gibson, Walker, Linton and Smith.

\section{Cedarville 46, Urbana 28}

The Yellow Jackets started the season by whipping a small but scrappy Urbana College team by the decisive score of 46 to 28 . This auspicious start was made upon the home floor. 


\section{B A S K E T B A L L}

\section{Cedarville 28, Franklin 22}

Cedarville met their first real test of the season and came through with flying colors, defeating Franklin U. 28 to 22 .

\section{Cedarville 37, Defiance 42}

A somewhat stage-struck Cedarville tive trailed Defiance 28 to 12 at the half, but showed their fighting qualities by coming back and nearly catching the visitors.

\section{Cedarville 30, Wilmington 23}

After years and years and years we finally did it! Cedarville hadn't defeated our traditional rivals in basketball for years but this year they killed the jinx by trouncing Wilmington rather handily 30-23.

\section{Cedarville 25, Defiance 26}

The Yellow Jackets journeyed to Defiance and after leading most of the game lost a heartbreaker 26 to 25 for their second defeat of the season.

\section{Cedarville 27, Bluffton 54}

It was unfortunate that the Yellow Jackets' only really bad defeat had to come before the Homecoming crowd but it just couldn't be helped. Bluffton had an unusually fine team and Cedarville was nervous: These two things taken together accounted for the size of the score.

\section{Cedarville 32, Wilmington 21}

Proving their ability to "come back," our boys went to Wilmington and in a rather listless game whipped them for the second time this season by the score of 32 to 21 .

\section{Cedarville 36, Rio Grande 31}

In an overtime game Cedarville defeated Rio Grande by scoring ten points in the extra period.

\section{Cedarville 4I, Franklin 40}

In one of the most peculiar games on record Cedarville managed to defeat Franklin by one point. Trailing at one time during the first half 17 to I. Cedarville spurted and led at the half 23 to 21. Near the end of the game Franklin again led 39 to 28 but by a great last minute rally the Yellow Jackets pulled through.

\section{Cedarville 35, Bluffton 44}

The Yellow Jackets dropped their last game of the season at Bluffton by the score of 35 to 44 .

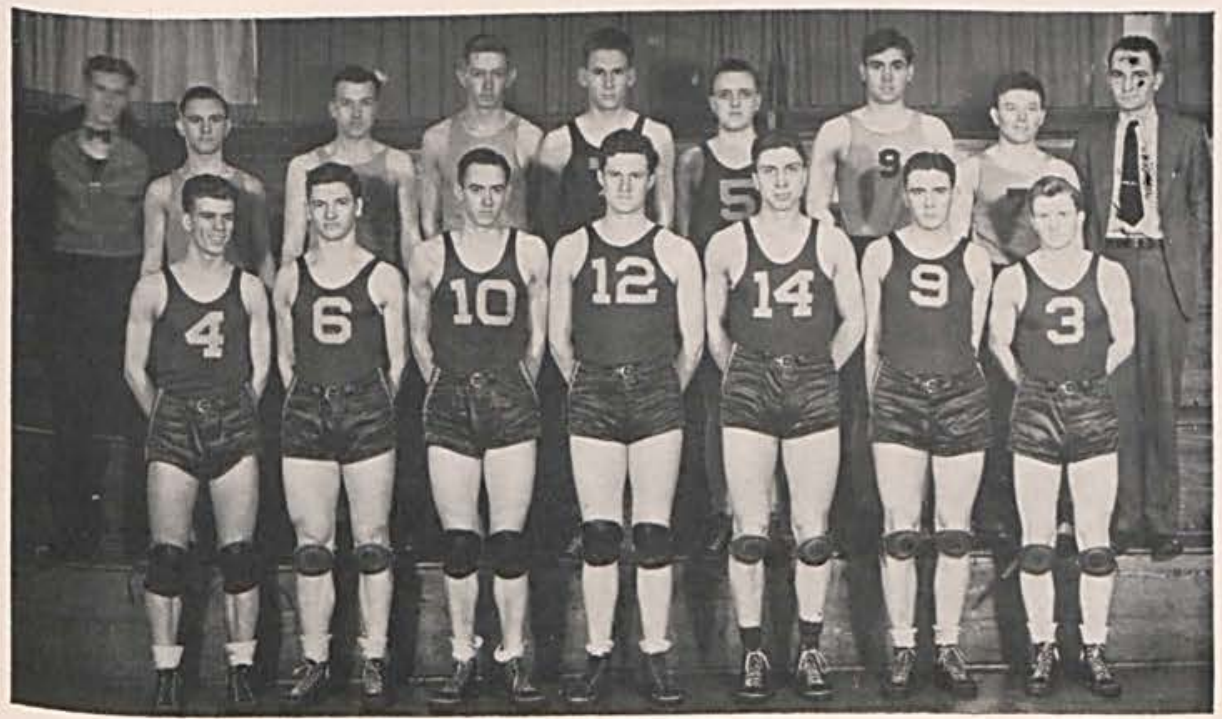

First Row: Walker, R o s s, Gibson, Swaim, Smith, H. Wallace, Waddle.

Second Row: Mgr. Cum mings, Sisson, Reed, McDonald, Thomas, Linton, F o u $1 \mathrm{k}$, Gillespie, Coach Ault. 


\section{B A S E B A L L}

Cedarville College is proud of their 1935 baseball team. This team won the conference championship. It is our hope that with this record behind them they will do even better this year and in the future.

\section{'35 SCHEDULE}

Cedarville....... 4 Wilberforce ...... 10

Cedarville....... 8 Defiance ........ II

Cedarville....... 8 Wilmington ...... 12

Cedarville....... 3 Wilberforce ...... 7

Cedarville....... 3 Bluffton ......... I

Cedarville....... 5 Defiance ........ 4

\section{BASEBALL SPRING OF 1935-}

\section{Cedarville 4, Wilberforce 10}

Handicapped by having four men in the line-up who never played a game of baseball before in their lives Cedarville dropped a 10 to 4 decision at Wilberforce in the first game of the season.

\section{Cedarville 8, Defiance II}

Although showing improvement in the offensive side of the game Cedarville lost their second game in a row to Defiance 11 to 8 . A wet field was responsible for the visitors' getting 8 infield hits which really decided the ball game. This was the first conference game.

\section{Cedarville 8 , Wilmington 12}

Cedarville again let loose a powerful attack but Wilmington was even more powerful and so the third successive loss occurred by the score of 12 to 8. Gillespie, a Freshman, hurled the last 4 innings and was handicapped by poor support.

\section{Cedarville 3, Wilberforce 7}

An improvement in the defense was matched by a letdown in offense and caused Cedarville to drop another game to our ancient rivals from Wilberforce by the score of 7 to 3 .

\section{Cedarville 3, Bluffton I}

Marvelous 2 hit pitching by V. Garlough brought Cedarville its first victory of the season by the rather close score of 3 to I. This was only the second conference game so a chance to win the championship was gained by this victory. 


\section{B A S E B A L L}

\section{Cedarville 5, Defiance 4}

The members of the Cedarville baseball team travelled to Defiance with the knowledge that victory would bring Cedarville its first trophy in the conference. Supporting the steady hurling of Garlough in a sensational style both in the field and at bat the tea mcame through and became Champions of the Conference. Each outfielder made a spectacular catch, Gillespie's leaping catch, after a long run to deep center saving a sure home run, being the best. B. Wallace led the offense with a triple and double with men on the sacks.

The Cedar Day game with Wilmington was washed out by a heavy downpour.

\section{BASEBALL, SPRING OF 1936}

\section{Cedarville 3, Wilberforce 2}

In this first game of the season Cedarville's team showed that it has been strengthened greatly over last year. Garlough pitched a nice steady game and the whole team played steadily back of him. Because rain delayed the game it was limited to 7 innings. However 8 were necessary as the score was $2-2$ at the end of the 7 th.

\section{Cedarville 5, Defiance 0}

Cedarville won its second victory of the season and its first conference victory behind brilliant pitching by Garlough, who registered his first shutout since coming to Cedarville College.

\section{'36 SCHEDULE}

Cedarville..... 3 Wilberforce .... 2

Cedarville....5 5 Defiance ..... 0

Cedarville...... 4 Wilberforce .... 13

Cedarvilie..... 8 Wilmington .... 7

Cedarville...... Defiance .......

Cedarville...... Bluffton .......

Cedarville..... Wilmington ....

\section{Cedarville 4, Wilberforce 13}

It was just an off day for everybody. Thompson started on the mound, received poor support and was succeeded by Garlough who was hit harder than usual.

Prospects for a successful season in baseball are very bright. Last year's championship outfit loses only one regular by graduation-Christian-and many Freshmen with real ability have appeared to take his place. In fact the Freshman material is so good that it isn't beyond the realm of possibility that some of last year's regulars may lose their jobs, all in all there seems to be no reason why an even better season cannot be had this year.

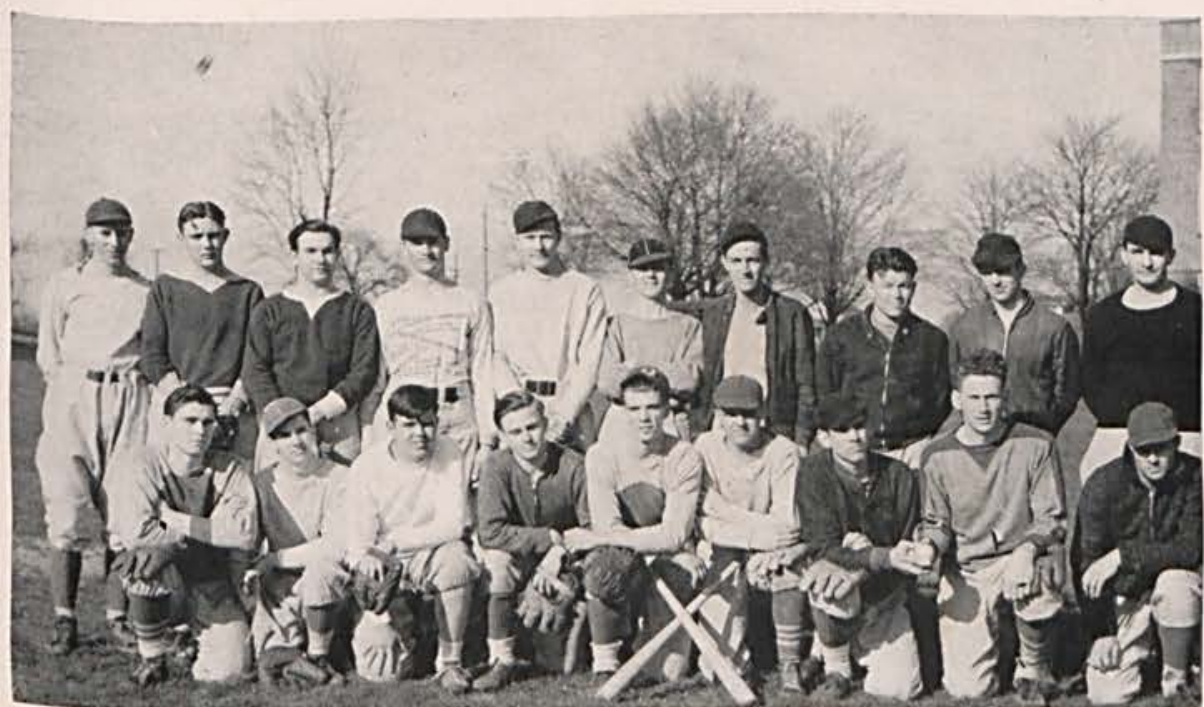

1936 BASEBALL SQUAD First row: Foulk, Ford, Prescott, Sisson, Walker, Linton, Thompson, Thomas, Jackson.

Second row: Garlough, Wallace, Murray, Ross, King, Waddle, ceed, Gillespie, Waddle, Coach Ault, Mgr.
McCorkell. 


\section{BOYS' INTRAMURALS}

Cedarville has no regularly organized intramural sports except the class basketball tournament. The members of the physical education classes play soccer, softball, tennis, basketball, and volleyball so that practically everyone can participate in some kind of game if they so desire.

\section{THE CLASS TOURNAMENT}

In the first game of the tourney the Sophmores and Juniors tangled. This proved to be the most interesting game of the whole tournament. The Juniors led all the way and finally won 29-25, but the Sophomores kept right on their trail the whole game.

The Freshmen easily defeated the Seniors 38-26. The Seniors had no men on the basketball squad. while four of the Freshmen were on the first squad of the varsity.

In the final game the Freshmen swept on to the championship over the former champs, the Juniors, by the score of 35-20.

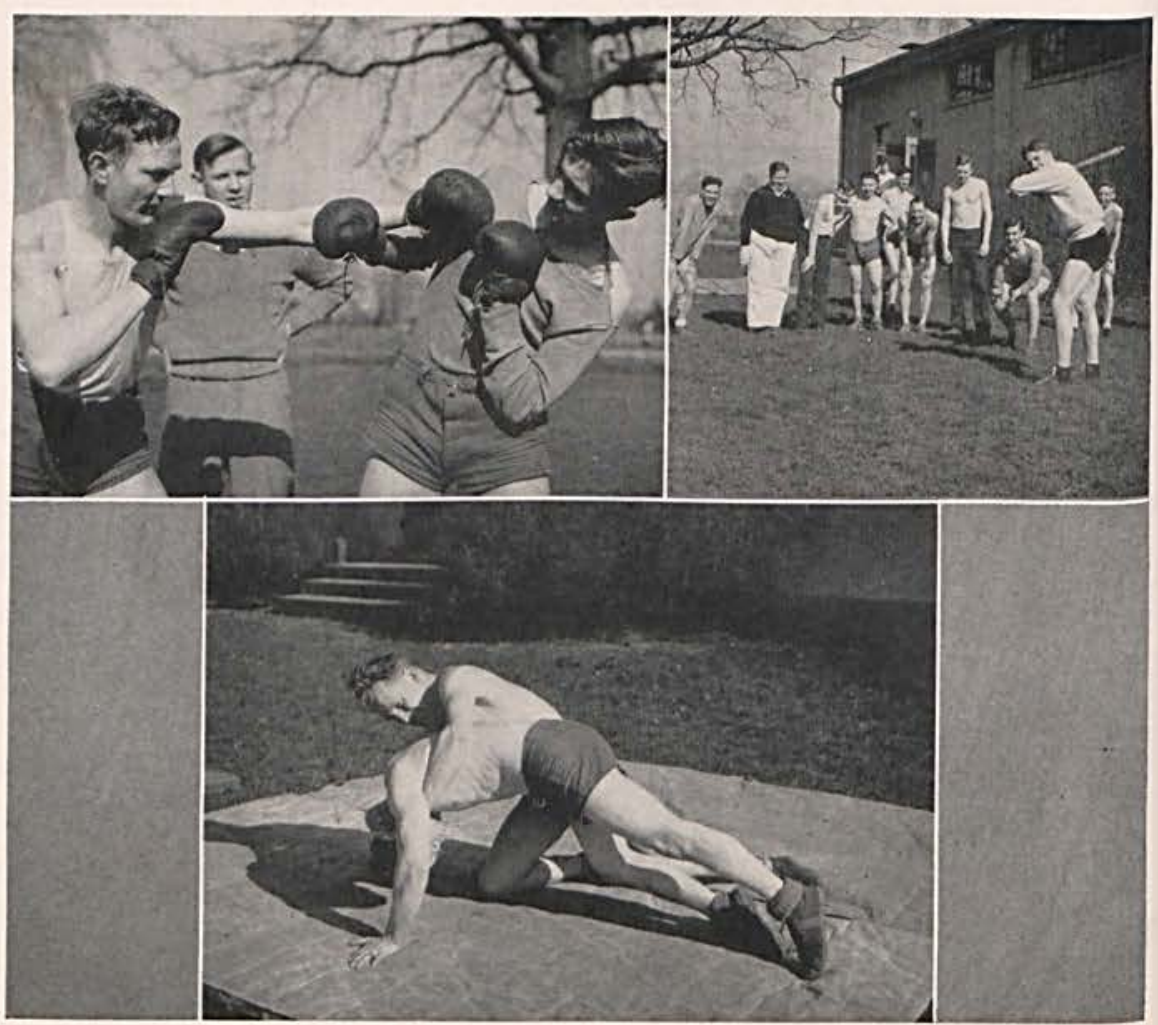




\section{GIRLS' GYMNASIUM}

The Girls' Physical Education class, under the direction of Dorothy Anderson, meets two times a week for instruction in basketball, softball, volleyball, and various types of gymnastics.

In the early fall, as much time was spent outdoors as the weather permitted. Many interesting hikes were taken and the beauties of nature in the autumn were enjoyed.

During the basketball season, we had scrimmages among ourselves and occasionally a tilt with the local High School girls. At these times, we were usually very badly beaten, but then, so were most of the other teams that met the High School team this year.

On March 14, a good many of the girls went to Cincinnati where they participated in the "Play Day for College Girls." Our girls entered in volleyball, swimming, and basketball.
The Girls' Gym Class of '36 extends to their physical director, Miss Dorothy Anderson, a vote of thanks for her efforts to aid them in developing the physical side of their lives.

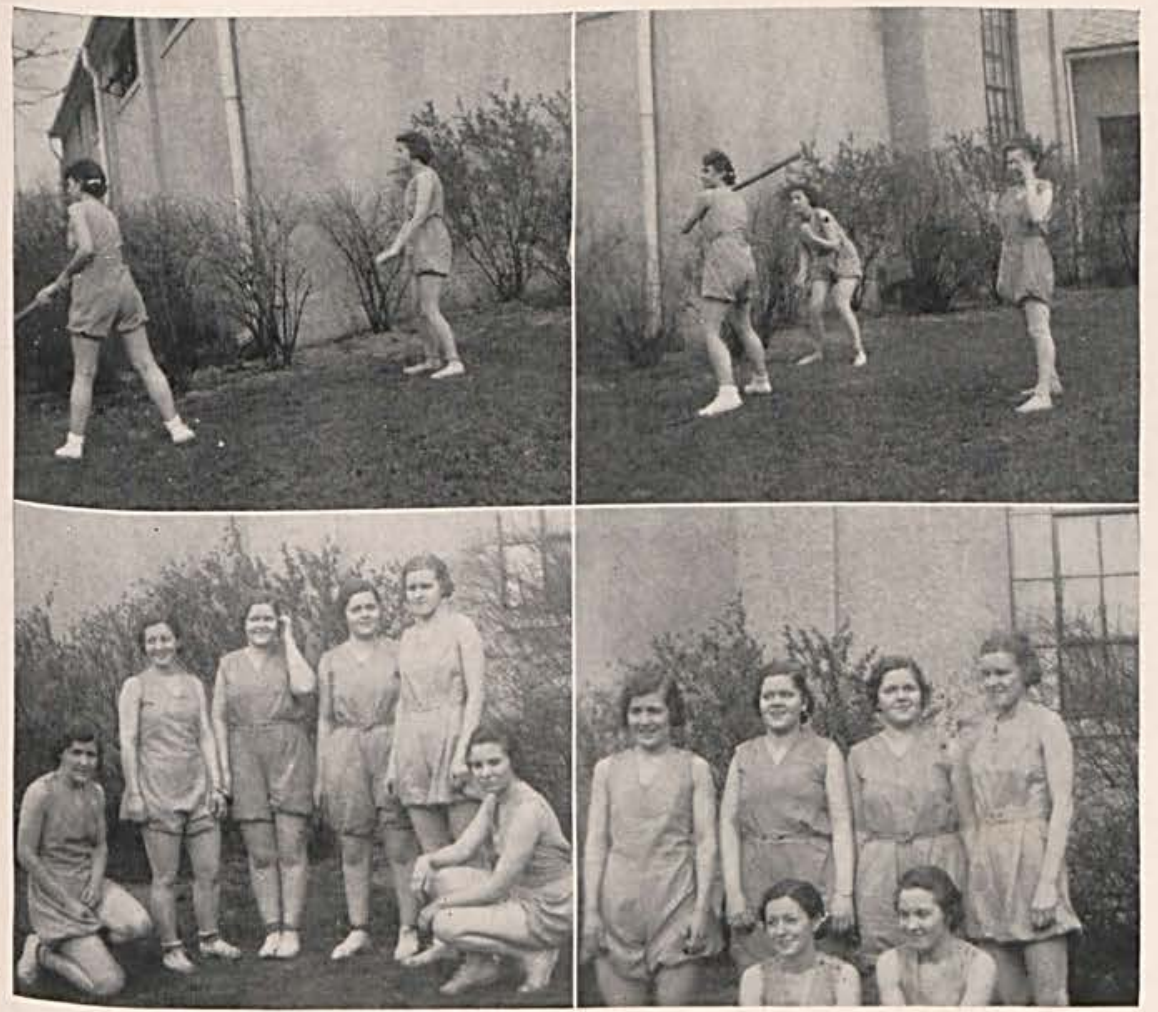




\section{TRACK}

Last year C. C. entered a new sport in intercollegiate athletics. Two men who had been active in high schools practiced by themselves and went to the conference meet. They did very well and C. C. is justly proud of this new addition to its sports.

Cedarville was represented by two members in the Northwestern Conference Track Meet last spring.
Cedarville scored a total of $111 / 2$ points, Brigham taking first in the high hurdles and tied for third in the high jump, while McCorkell took second in the mile run.

Brigham hung up a record for Cedarville, clipping a second off the old record in the high hurdles.

It is hoped that in the future Cedarville may again be represented in this new sport. 



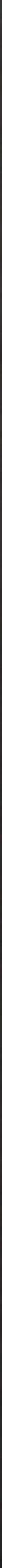


\section{5 and 1936}

\section{JUNIOR-SENIOR BANQUET}

In spite of the constant drizzle outside, the banquet room of the Bancroft Hotel was a scene of fellowship as the Juniors of ' 35 entertained the graduating class and faculty on May 20.

When appetites had been satisfied our squadron took to the air with Joe West at the controls. Russell Murray welcomed the guests and Carl Ferguson responded. We sailed through the musical realm by lovely selections given by Dorotha Corry. Anna Jane Wham and Harriet Ritenour. Appropriate readings were given by Mrs. Heintz and Miss Basore.

Eugene Corry explained the technique of "Flying in Formation": Mildred Labig pointed out the need of "Following the Beacon," and Donald Burkert prophesied a "Successful Flight." Closing remarks by $\mathrm{Dr}$. McChesney ended a delightful flight.

\section{FACULTY RECEPTION}

The faculty reception for students and friends of Cedarville College was held in the gymnasium on June 4.

The Dramatic Club under the supervision of Dean Louise T. Heintz presented two one act plays, "Thank you, Doctor," and "Betty Behave!"

The Glee Club and the Orange and Blue Serenaders under the direction of Mrs. Margaret J. Work rendered several beautiful musical selections.

There was enough punch for everyone-even the "thirstiest" freshman.

\section{McCHESNEY'S RECEPTION}

Dr. and Mrs. McChesney gave their annual reception for the students and faculty of the college.

This occasion is always anticipated with great joy by all those who have been in attendance in previous years. Our gracious hostess, Mrs. McChesney, served lovely refreshments during the evening.
She also planned a program of group singing. The students and faculty wish to express their thanks and appreciation for this annual event.

\section{CROWN CLUB}

The C. C. C. C. was organized several years ago to promote scholarship and to honor those ranking high in scholastic attainments.

The commencement of ' 35 welcomed into the Club the following students: Winifred Maxine Bennett, Olive Brill, Annabel Dean, Walter A. Linton, Harriet Ruth Ritenour, and Franklin L. Trubee.

\section{BACCALAUREATE}

The Baccalaureate Service was held in the United Presbyterian Church on June 2. The sermon was delivered by Dr. W. R. McChesney, President of Cedarville College.

Special music was furnished by the Cedarville College Mixed Chorus and the Girls' Trio.

\section{COMMENCEMENT 1935}

The Thirty-ninth Annual Commencement was held in the Opera House, Friday, June 7. There were nineteen seniors, fourteen graduates in the two-year course, and one graduate in music.

Those who graduated with honors were: Magna Cum Laude, Carma Hostetler, Walter A. Linton. R. H. Tindall, and Franklin L. Trubee; Cum Laude, Annabel Dean, Carl Bruce Ferguson, and Luella Robe. The honorary degree of Doctor of Divinity was given to Carl H. White, Guy Cheek, and David Harold Hammond.

The address was given by the Rev. Donald $H$. Tippett, D. D., the minister of the Methodist Episcopal Church, Bexley, Columbus, Ohio.

The stage had been decorated for the occasion by the members of the Junior Class. Music was furnished by an orchestra from Wilmington, Ohio. 


\section{5 and 1936}

\section{WOMEN'S BIBLE CONTEST}

The Women's Bible Reading Contest was held Sabbath evening, March 29, 1936, in the United Presbyterian Church. This contest is sponsored by Miss Margaret B. Rife, an alumna of Cedarville College. This contest is an annual event and is always anticipated by the girls of the college.

The Mixed Chorus, directed by Mrs. Margaret J. Work, and accompanied by Miss Dorotha Corry, furnished the music.

The contest was a close one this year and the winners are as follows: first prize, a tie, Majel Porter and Christine Tobias; second prize, Gladys Bumgarner; third prize, Betty Fisher, and fourth prize, Rachel Creswell.

\section{JUNIOR CLASS PLAY}

The annual Junior Class Play was presented the fifth of March in the Cedarville Opera House. The play, "Forever True," was presented by a cast consisting of Ruth Kimble, Esther Waddle, Dorothy Anderson, Betty Fisher, John Richards, Gale Ross, John Tobias, and Paul Angell. Miss Glenna Basore ably directed the play.

The plot centers around a family of wealthy Americans whose son married an Irish girl, bringing her to America to live with his family. The mother was very jealous and systematically began her attack to drive the girl away. This was done and the play jumps to the present, and the daughter takes the stage. She is brought from Ireland by friends of the family and tries her best to win the heart of her father. An aunt who makes her home with the father tries to do to the daughter just what the mother did before her. In this she was foiled by the faithful Irish butler, and the story ended happily for all. The Junior class is grateful to Miss Basore without whom the play could not have been a success.

\section{METHODIST PARTY}

The Epworth League of the Methodist Church delightfully entertained the students and faculty of Cedarville College at a leap year party in the Alford Memorial Gymnasium on March 17, 1936.

The party began with a grand march, followed by musical and folk games of European and American origin. Refreshments following the St. Patrick's Day color scheme were served.

A Friendship Prayer Circle, during which the group sang "Follow the Gleam" and observed a few moments of silent prayer, completed the evening's entertainment.

\section{FRESHMAN WEEK}

People walking backwards, girls without make-up, boys with make-up, a strange vision of the future? No! Just Freshman Week at Cedarville College.

It seemed to many Freshmen the requirements were endless. Many rather timid Freshmen studiously memorized their duties for each day. We had to bow to every upper classman. Woe to them that refused! We had to wear clothes back. wards, wear shoes that weren't mates and do many other humiliating things. However, most Freshmen secretly enjoyed themselves during this week.

Many boys had romantic moonlight hikes during this time-but by themselves.

The climax of the week came on Thursday. At this time the girls had the task of scrubbing a wheelbarrow full of mud off the college steps. The boys had the pleasant experience of running around the baseball diamond while the Sophomore boys applied their belts most advantageously.

Then came the tug-of-war. This was held at Willow Bend. The Freshman boys had an invigorating swim.

A snake dance over town and a huge bonfire on the college campus closed Freshman Week for another year. The Freshmen were now a fullfledged part of the Student Body. 


\section{CANDID CAMERA}

These views of Cedar Day and Commencement bring to us again the mental pictures presented on those days. We remember not only those here recorded, but also the class stunts-the May-Pole dance-the rainbow dance-the athletic exhibitionsthe Master of Ceremonies-and the Goddess of the Rainbow.

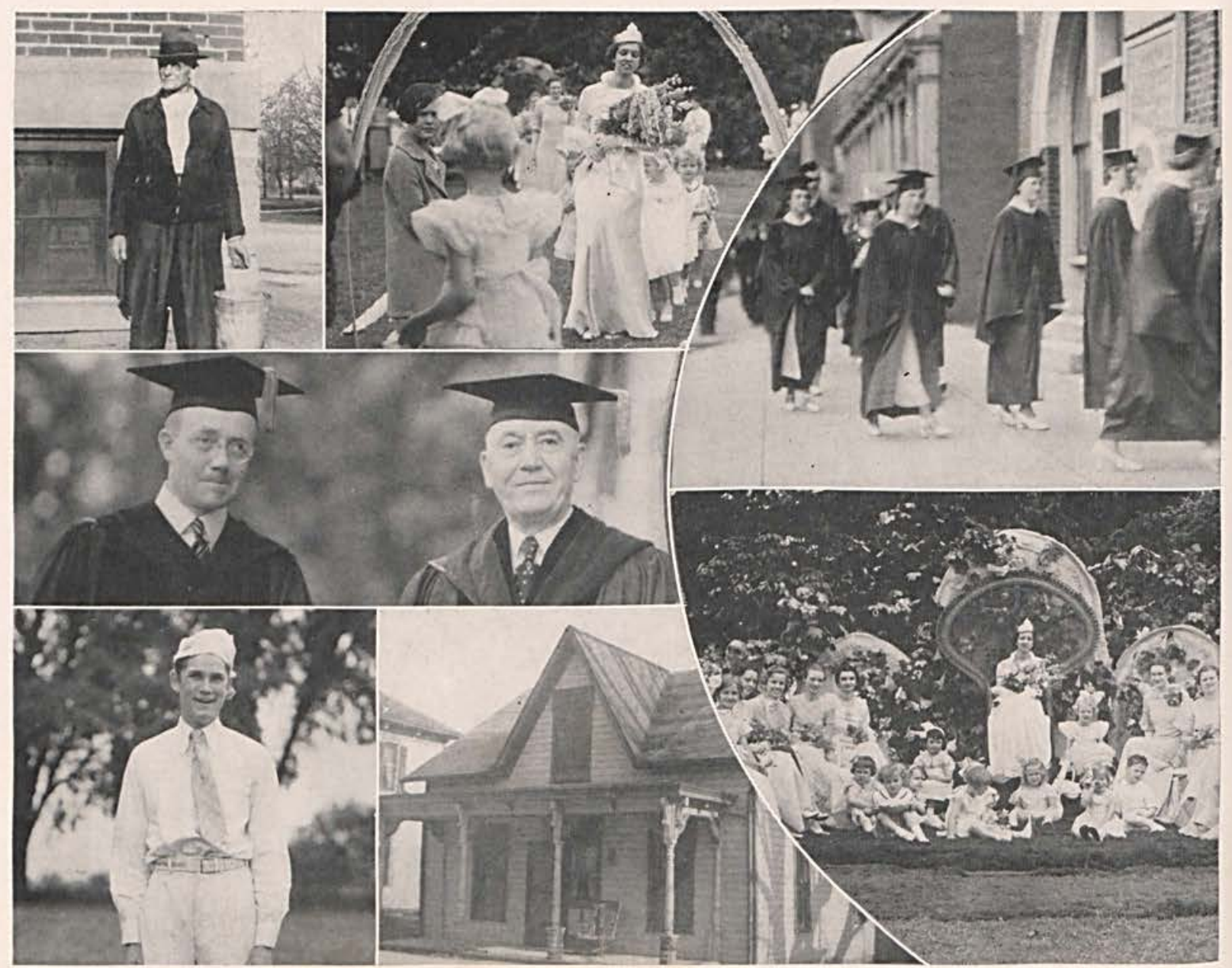




\section{A M E R A}

Our mental pictures of Commencement remind us of the honorary DD's-the cum laudes-the magna cum laudes-the Crown Club-the pastors of the churches-that final address by the President-the beautifully decorated stage-the lovely music of the Ensemble-and our old friends in long black robes.

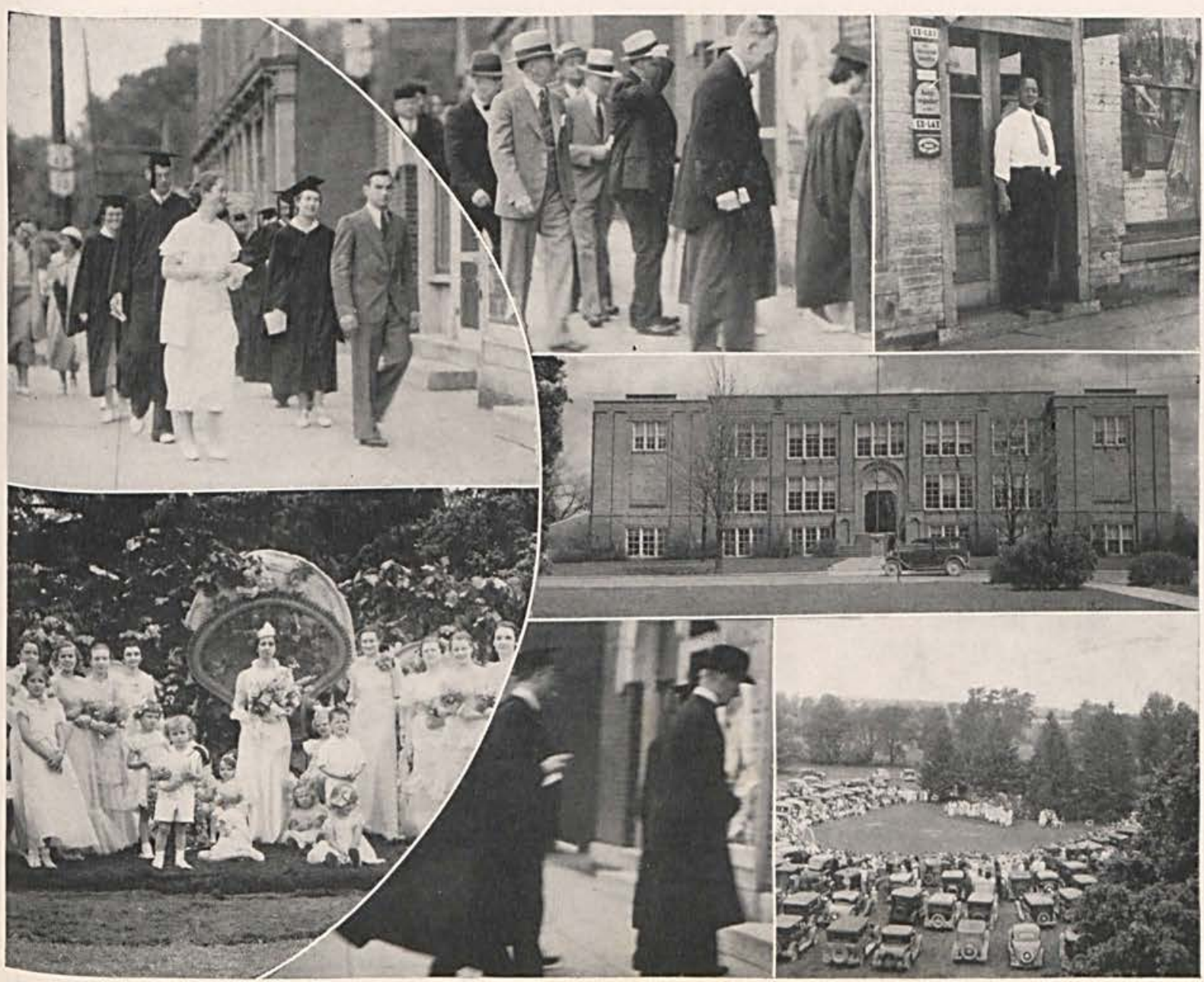




\section{CEDARVILLE}

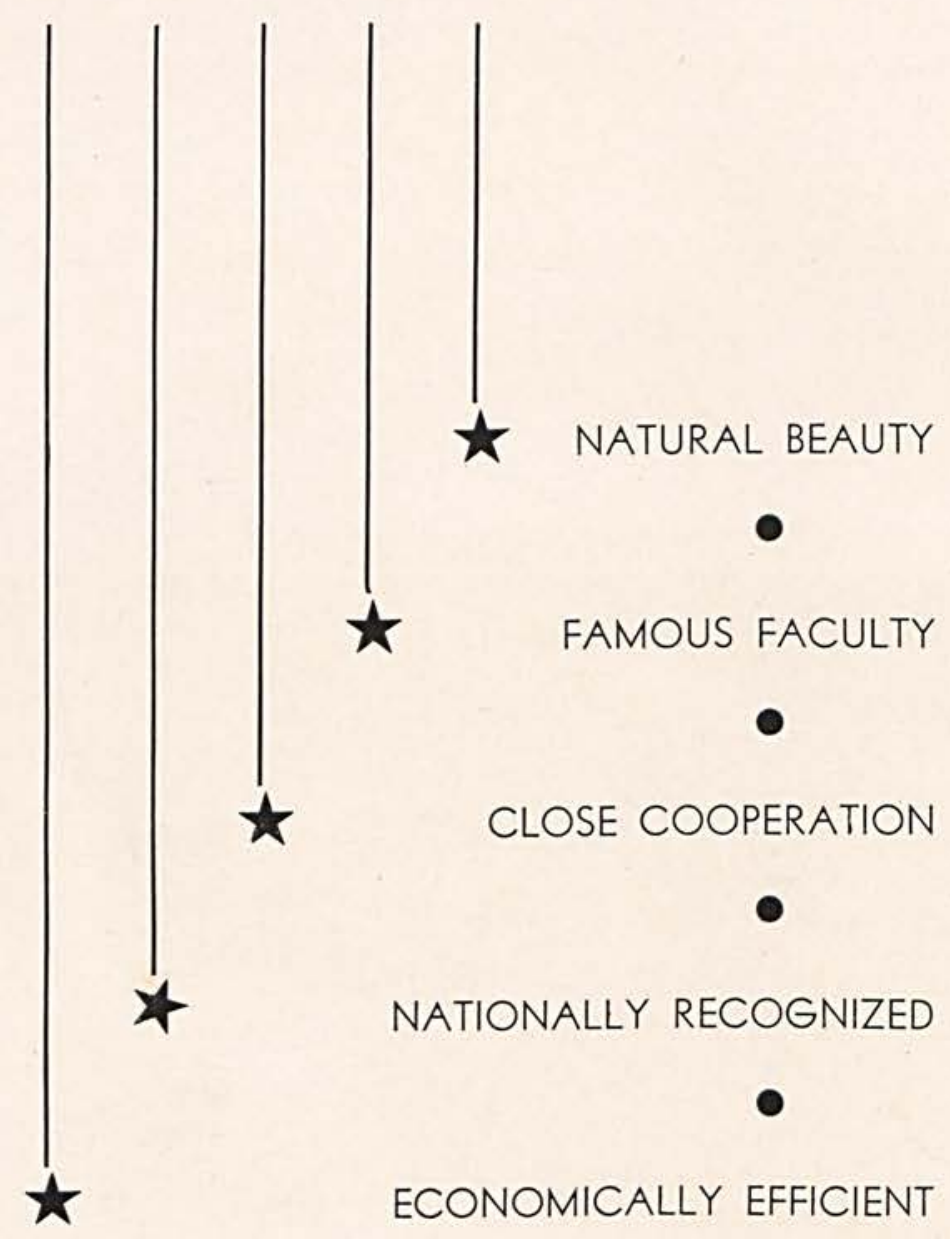

42 YEARS OLD

SUMMER SCHOOL

OPENS

JUNE 8-JULY 13 


\section{O L L E GE}

The College is recognized by the Department of Public Education of the State of Ohio, and by the leading universities. The Faculty is experienced and thoroughly trained.

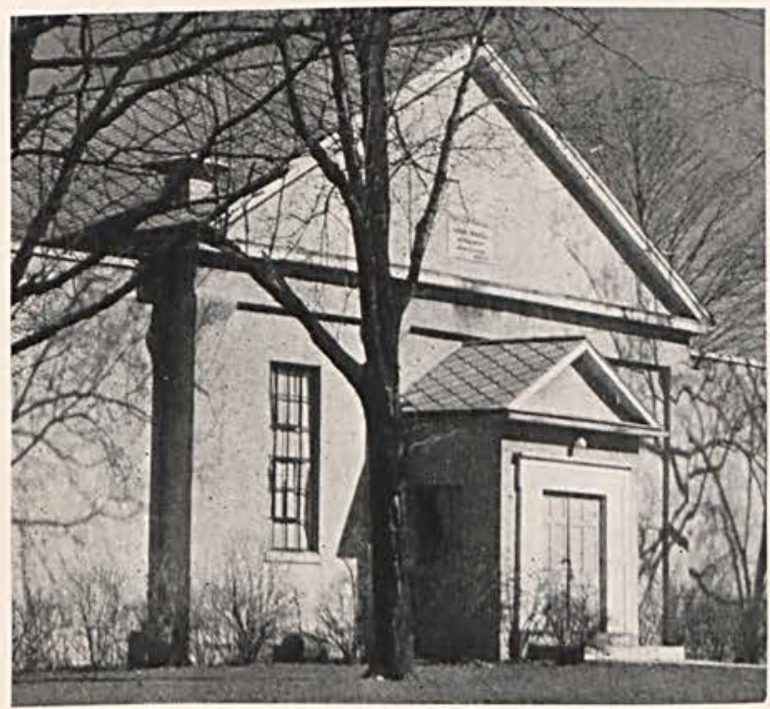

Come

to

Cedarville

College!

Write for catalogue and information

W. R. McCHESNEY, Ph. D., D. D., President

Cedarville, Ohio 


\section{A N D I D}

After all, what is the more important part of college life? Is it the long hours of recitation, the midnight hours of study, the anxiety about exams, and the credits earned? Or is it those vacant hours spent on the steps of "Old Main", or in the Chapel, those lazy hours beneath the cedar trees, those moonlight strolls with that "someone", those hikes to the cliffs, those lasting friendships formed, both with the students and faculty?

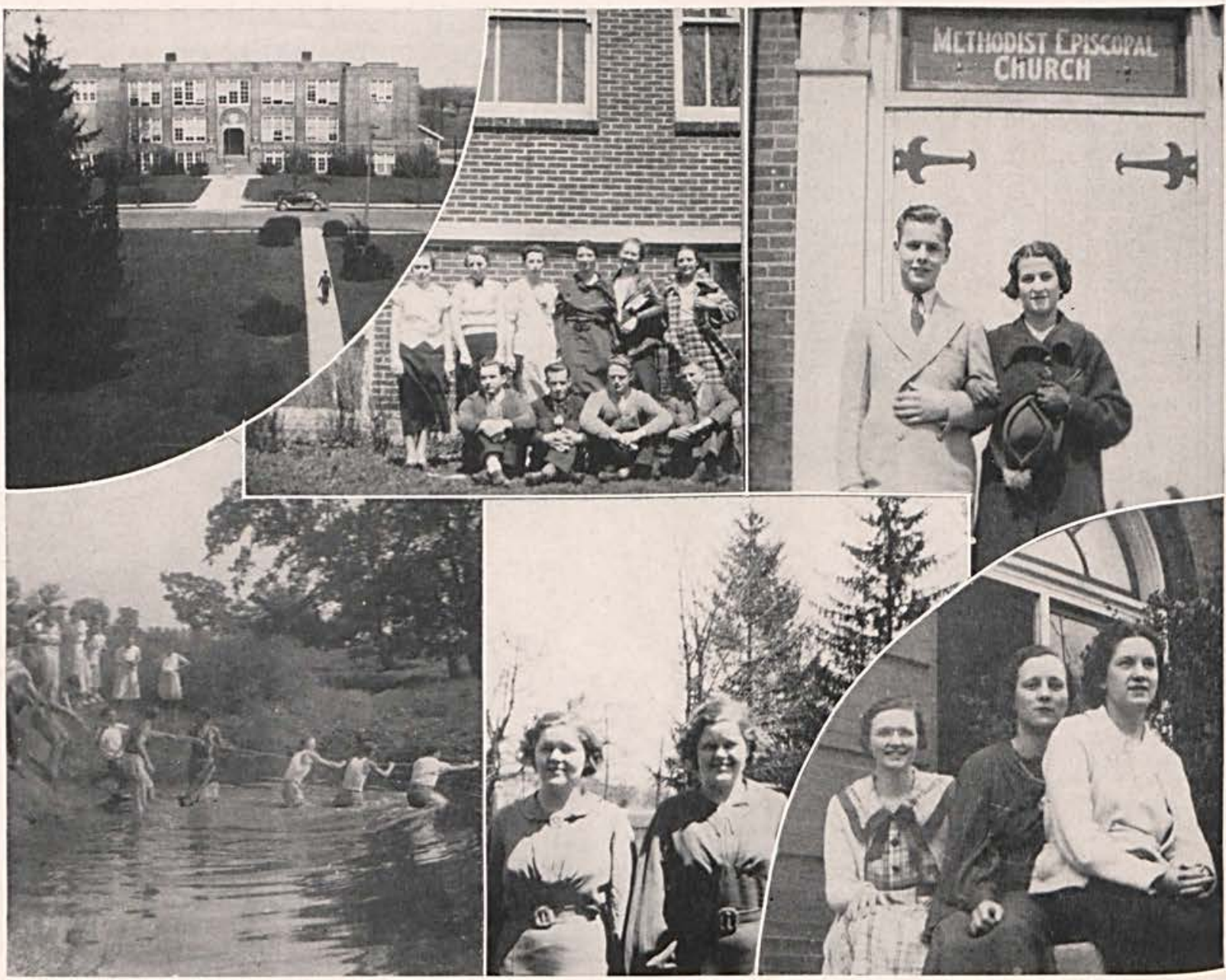




\section{A M E R A}

It is not for us to say which is the more important, both phases are necessary to the complete college life; both must be preserved by means of pictures. With all due respect to the artiste, Axel, perhaps more interesting than the posed pictures of student and faculty are those informal scenes caught when someone was "there with a Brownie".

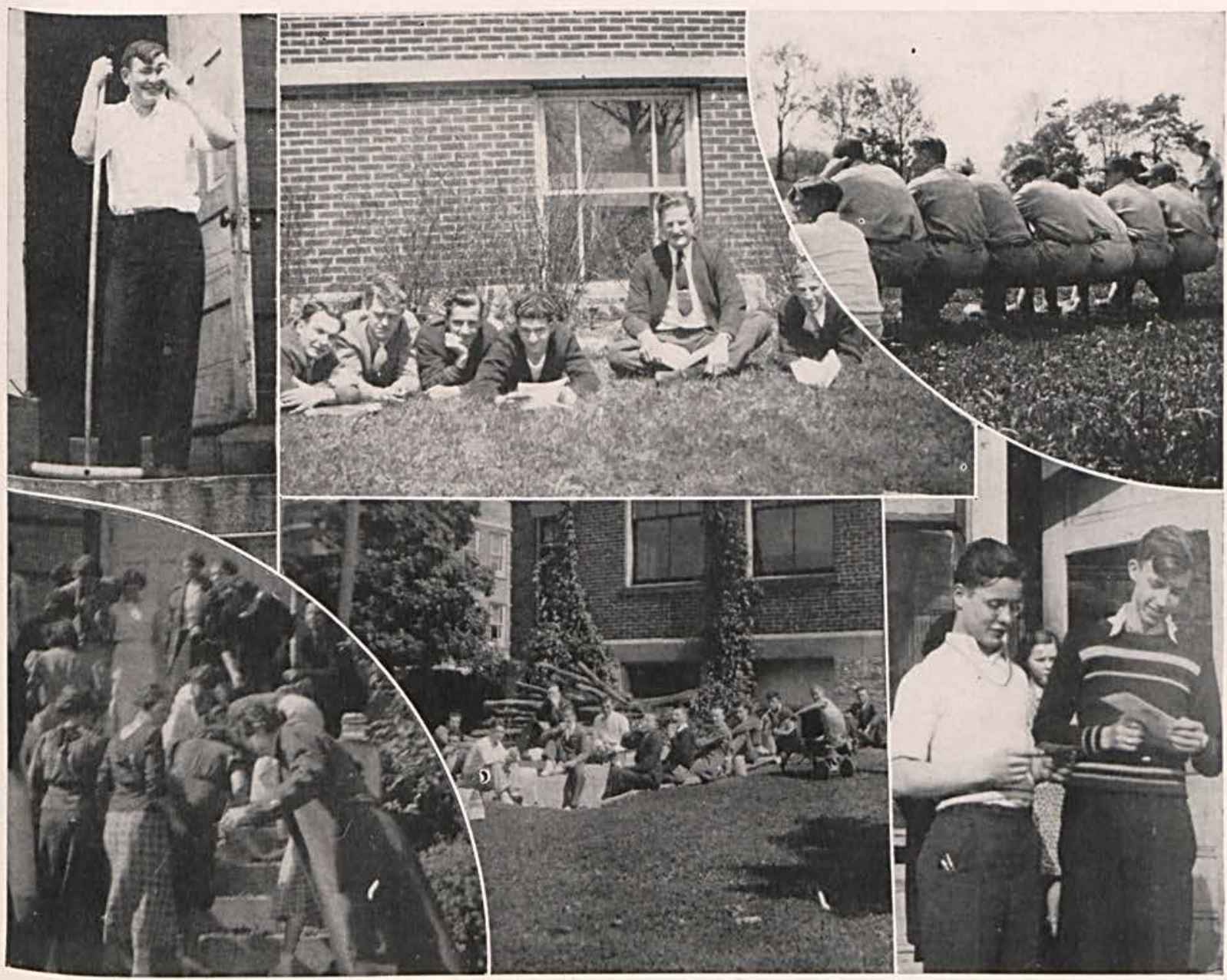


With our compliments to the "1935" Cedrus

THE OHIO INDEPENDENT OIL CO.

— Your friendly neighborhood service -

ce

Distributors for

FLEET-WING GASOLINE - U. S. L. BATTERIES

FLEET-WING "PENN" MOTOR OILS-U. S. TIRES

Cedarville

Phone 68

Ohio

\section{BROWN'S DRUGS}

THE REXALL STORE

SPORTING GOODS

for

BOYS AND GIRLS

$* * *$

BASEBALL - SOFTBALL

TENNIS - GOLF

RACKETS - RESTRUNG

FISHING TACKLE

\section{THE RECO STORE}

16 W. High St.
"The Best in Drug Store Merchandise

The Best in Drug Store Service"

Visit Our Fountain

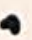

REDWING ICE CREAM

Served Exclusively 


\section{THE \\ CEDARVILLE HERALD}

COMMERCIAL - CATALOG

JOB PRINTING

LET US GIVE YOU

AN ESTIMATE ON

YOUR PRINTING

\section{PAUL EDWARDS}

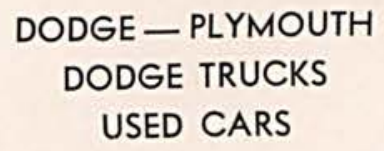

Phone 147

S. Main St.

Cedarville, 0 .

\section{MARION ALLEN}

ICE SERVICE

CEDARVILLE, OHIO

\section{LEO ANDERSON, D.V.M. VETERINARIAN

\section{THE}

HAGAR STRAWBOARD \& PAPER COMPANY

Cedarville, Ohio

$6 \% 0$

FINE STRAW BOARD

FOR CORRUGATING

\section{CROUSE'S GROCERY STORE}

FRUIT - MEAT — VEGETABLES

Phone 40

Cedarville

Ohio

H. L. PICKERING

Electrical Supplies

Radio Repairing

Phone 22 CEDARVILLE, OHIO

\section{LANG CHEVROLET XENIA, OHIO}




\section{ALUMNI BANQUET}

The annual Alumni Banquet was held in the Alford Memorial Gymnasium on Thursday evening, June 6, 1935. Following the dinner which was served by the Ladies' Advisory Board, Dr. James L. Chestnut, ' 18, president of the association, acted as toastmaster and announced the program which was as follows: Invocation, Rev. Walter P. Harriman, '12; Welcome to Class of 1935, Homer Murray, '34; Response, Robert Harriman, '35, Bernese Elias, '32, and Dallas Marshall, '30. President W. R. McChesney delivered the main address and the College Girls' Trio sang several numbers.

Following the program, a short business meeting was held and the following officers were chosen for 1936: President, Clair McNeel, '29; Corr. Secy., Marjory Wright Peterson, '23; Rec. Secy., Helen Iliff Jacobs, '28; Executive Committee: Ina Murdock, '07, Wilda Auld, '32, Martha Waddle, '32, and Eleanor Bull, '35.

\section{MOTHER-DAUGHTER BANQUET}

The Y. W. girls entertained their mothers at the college gymnasium on May 15. The dinner was prepared by a committee under the direction of Betty Fisher. The decorations were prepared by a committee headed by Mary Johnston and Ruth Kimble. After the dinner the program planned by Olive Brill was given. Our president, Anna Jane Wham, was the toastmistress. Olive Brill welcomed the guests and Mrs. Leroy Jacobs represented the mothers in the response. The Girls' Glee Club sang "Mother," the words of which were taken from a poem by Grace Noll Crowell and set to music by our director, Mrs. Margaret J. Work. Miss Glenna Basore gave a reading, "Johnny Gets Ready for Company." The Girls' Quartette sang "Mother Machree" and "Mother of Pearl." The address of the evening was given by Mrs. Paul D. Espey of Xenia.

\section{Y. M. MINSTREL}

The college minstrel given Thursday evening, March 26, 1936, was a great success. Built around a theme of naval character the boys sailed away on a trip on the good ship "U. S. S. Cedrus" that led them in the land of "Old Black Joe." While under the "Moon Over Miami" they met "Barnacle Bill" and "Pop-eye the Sailor Man." Others of prominence in the crew were "Crooner Grube" and the "Fair Young Maiden" (Sisson). "Admiral" Donald Burkert disproving some of the songs sailed with his crew and governed the actions of the deck swabbing end men Fuss-button Tobias, Asbestos Walker, Asphalt Tomlinson, Bituminous Beals, Bilious Anderson and Electricity Gillespie. The crew lazied in southern skies and returned to the tune of "Shipmates Forever." The voyage was a success, the minstrel was a success and the $Y$ treasury was a success. The production was entirely under college boys and their talent. E. Corry supervised the music, D. Burkert the dialogue, F. Trubee the stage and business, with R. Murray over the whole show. Honor is due Noah Sharpe, A. Murray, Prescott and Buehler who helped on the stage. It is recommended to future stage managers to look for Sharpe. Also credit goes to Forrest Nagley and Peterson for their special music.

\section{UNITED PRESBYTERIAN PARTY}

On Sept. 17, the social whirl began with a college party in the social room of the U. P. Church. A "college party" was the entertainment for the evening. Classes consisted of history, physical education, arithmetic, spelling, and geography. The geography course consisted of a study of our town. The students had quite a time counting bridge spikes and fence posts, and hunting signs. The evening closed with refreshments. We hope you had a good time and invite you back next year. 


\section{MOCK WEDDING}

The Y. W. girls, under the guise of a May Breakfast, held the traditional Mock Wedding at the home of Dortha Corry at 5:30, May 1. The members of the bridal party were: Bride, Dorotha Corry; Groom, Mildred Labig; Preacher, Julia McCallister; Maid of Honor, Olive Brill; Best Man, Harriet Ritenour; Bridesmaids, Betty Fisher, Jane Frame, Jeanne MacKnight, and Betty Shaw; Ushers, Christina Jones, Majel Porter, Mary Johnston, and Kathleen Miller; Bride's Father, Esther Waddle; Bride's Mother, Beatrice McClellan; Flower Girl, Ruth Kimble; Ring Bearer, Robinette Williams; Pianist, Mrs. Work; and Soloist, Anna Jane Wham.

Mrs. Work was playing the last march when the boys, according to the custom of Cedarville College, arrived on the scene. The girls made the boys work for their breakfast and added another successful mock wedding to their history.

\section{MEN'S BIBLE READING CONTEST}

As in previous years, Rev. C. M. Ritchie contributed the prizes for the annual Men's Bible Reading Contest which was held in the Presbyterian Church on the evening of October 27. The winning contestants were: James Anderson, first: Justin Hartman, second; Joseph West, third; Eugene Corry, fourth; Kenneth Sanderson, fifth.

This year's contest was particularly significant because 1935 marked the Four-Hundreth Anniversary of the printed English Bible.

\section{CEDAR DAY}

Cedar Day, 1935, featured an interesting and colorful pageant, "The College Rainbow," written and directed by Mrs. Anna Collins Smith, 17.

The pageant began with the entrance of the stately May Queen, Luella Robe, and her attendants.
After the queen was crowned by the queen of the preceding year, Regena Smith, the ladies-in-waiting presented her with her colors representing memory, truth, loyalty, joy, power, and hope. They were bound into her scepter.

A beautiful throne decorated with daisies made a lovely setting for the queen and her attendants.

After the presentation of the colors to the May Queen, the Goddess of the Rainbow, Eleanor Bull, brought greetings to the queen and created a college rainbow down which she led the student dancers in searching for a hidden treasure. They returned bearing the treasures of Knowledge, Friendship, Appreciation of the Arts, Professional Training, Religion, and World Friendship. These were presented to the queen for the use of all future generations of Cedarville College students. Ralph Tindall was the master of ceremonies.

The pageant featured many dances including the May Pole Dance, the Dance of the Rain Drops, the Sun Dance, and the Dance of the Clouds. Arthur Donaldson played the part of a Court Jester.

Walter Linton, the Cedar Day orator, gave a very helpful and inspirational speech in which he compared the game of baseball to life.

The traditional class stunts followed the presentation of the pageant. The program closed with appropriate remarks given by $\mathrm{Dr}$. McChesney.

\section{COMMENCEMENT RECITAL}

The annual Commencement Recital sponsored by the Cedarville College Conservatory of Music was held on Monday evening, June 3, in the Presbyterian Church.

There were organ, piano, and vocal solos. The girls' trio, the girls' glee club, the girls' quartette, and the boys' quartette also gave several numbers. 


\section{GALLOWAY \& CHERRY \\ FURNITURE - FLOOR COVERING DRAPERIES}

36-38 West Main Street

Phone 4

Xenia, Ohio

\section{HARRY D. WRIGHT}

GROCERIES

Member of White Villa

CEDARVILLE, OHIO

Compliments of

\section{Harner Electric Shop}

5 E. Main St. Phone $1167 \quad$ Xenia, Ohio

Subscribe

for

\section{"WHISPERING CEDARS"}

C. C. Student Paper

\section{OLD MILL CAMP}

Under New Management Prop.-R. H. THAYER

Home Cooked Foods-Ice Cream-Cold Drinks

Tea Room Available For SPECIAL PARTIES

Gulf Gasoline-Oil

Cabins-Tourist Accommodations

Phone 153-F5

Cedarville

\section{CALENDAR}

Sept. 9-Registration.

Sept. 11-First day of school.

Sept. 12-Y. W. C. A. Tea at Mrs. Work's home.

Sept. 15-Convocation.

Sept. 17-Party at United Presbyterian Church.

Sept. 19-Pajama parade.

Sept. 20-Everyone tired and happy.

Sept. 23-Senator Upshaw from Georgia, speaker at chape!.

Sept. 24-Y. M. and Y. W. Mixer.

Sept. 26-Class officers elected.

Sept. 30-Literary.

Oct. 1-Beginning of freshman week.

Oct. I-Tsh! Tsh! Mrs. Heintz went to Selma to rescue a certain freshman.

Oct. 2 Gosh, the boys look cute with hair ribbons, lip stick, rouge and earrings.

Oct. 2-Freshman Chapel.

Oct. 3-Freshmen baptized in ye old creek.

Oct. 3-College feed and parade.

Oct. 9-Girls in Y. W. surely aired their views and opinions about boy friends. Step carefully, boys.

Oct. 10-School picture taken.

Oct. 15-Freshman party and fire at South Charleston.

Oct. 16-Literary hay ride and hamburgers.

Oct. 27-Men's Bible Reading Contest-James Anderson. first.

Oct. 31-Annual Hallowe'en Party at Gym. Darn handsome crowd, I'd say.

Nov. 5-Can you believe it! Cedarville voted out beer.

Nov. 8-Sociology class visited transient camp at Osborn. Juvenile Court and Infirmary in Xenia.

Nov. 12-Baseball letters awarded.

Nov. 14-Y. W. Committal Service.

Nov. 20-Galloway speaks in chapel.

Nov. 20-Ault's dog driven to commit suicide-and more tears and red eyes.

Nov. 22-Our own Helen Baker Vanderpool is a proud mother.

Nov. 22-Richards using some line on frat members.

Nov. 24-Monks Club visited Methodist Church in Yellow Springs. 


\section{CALENDAR}

Nov. 26-Murder will out. It's rumored that Buehler was discovered in Prof. Steele's room playing post office.

Nov. 28-Thanksgiving vacation.

Nov. 30-Snow-Winter's here.

Dec. 4-Galloway spoke to joint meeting of $Y$. M. and Y. W.

Dec. 5-Cletis Jacobs and Helen Seamon chosen to lead the rah rahs!

Dec. 10-Cedrus Staff Play.

Dec. 12-It's rumored that Max Michael is playing Santa's helper over in the Science Building.

Dec. 16-College recitai.

Dec. 18-Secret Pal Party. Girls, did you miss your car?

Dec. 19-Home for Holidays.

Jan. 7--Back to the grind.

Jan. 13-Girls had an exam in Gym, want to know how to play basketball or soft ball? Just ask any of them.

Jan. 17-Rev. Gutherie went on vacation.

Jan. 21-O me, O my! Exams!

Jan. 22-Cold-I should hope to smile. Mercury dropped to 12 degrees below-below, below.

Jan. 27-At it again, Registration.

Jan. 29-Dr. Johnson and singers from Wilberforce entertained in chapel.

Feb. 6-Otto Vandevier Keurman made his debut.

Feb. 7-Day of Prayer.

Feb. 8-Homecoming Banquet and game.

Feb. 12-international Day at Wilberforce.

Feb. 25-Pictures taken for Cedrus.

Fob. 27-School dismissed-Bum waterworks.

Mar. 1-Break for Cedarville. Smiling Clarence moves to town.

Mar. 5-"Forever True" Junior Class Play.

Mar. 17-Methodist Church gave party.

Mar. 17-Rep. Marshall speaker in chapel.

Mar. 18-Preliminary Bible Reading (women's).

Mar. 19-Burke was seen on the campus chopping hunks with golf clubs.

Mar. 26-Y. M. Navy Minstrel.

Mar. 29-Bible Reading Contest-Two first prizes-Tobias and Porter.

Apr. 1-April fool.

Apr. 2-Easter vacation, or is it just a spring vacation?

\section{L. McGUINN}

COAL — FEED - SEED

GRAIN AND WOOL

MILLER STREET

Phone 3

Cedarville, Ohio

\section{NAGLEY'S \\ GROCERY}

"THE CORNER STORE"

Phone 104

Cedarville

THE

CRITERION

Value First Clothiers

Xenia, Ohio

\section{HAMMAN DAIRY}

Milk

Single and Whipping

Cream

Phone 197-R3 


\title{
STANDARD ICE CREAM
}

Goodness! How you'll like it.

\author{
\%)
}

Buy From

\section{RICHARD'S DRUG STORE}

DELICIOUS

Springfield Purity Dairy

NOURISHING

Springfield, Ohio

C. E. MASTERS

GROCERY and MEAT

Phone 44

Cedarville

DEPENDABLE

REASONABLE

Wrecking Service

DAY AND NIGHT

WOLFORD'S AUTO SERVICE

Phone 2-25

Cedarville, Ohio

\section{COVAULT'S BEAUTY SHOP}

Phone 434

Xenia, Ohio 


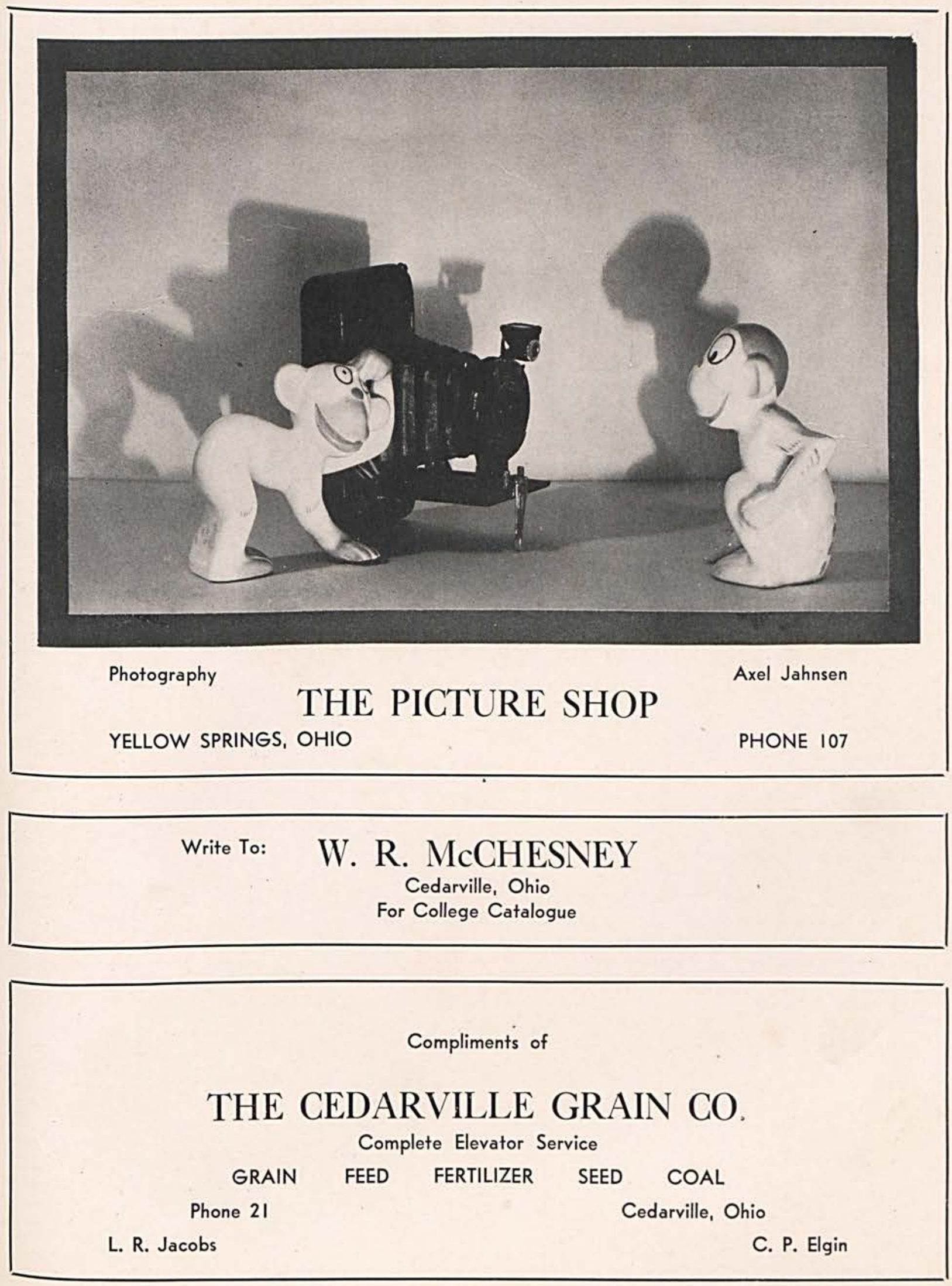




\title{
Need More Be Said?
}

\author{
1936 CEDRUS \\ Cedarville College \\ CEDARVILLE, OHIO
}

Joe West, Editor

Mr. Frank Mawicke

Pontiac Engraving and Electrotype Co.

812 West Van Buren Street

Chicago, Illinois

Dear Mr. Mawicke:

I want to take this opportunity to express to you and your company our appreciation for the way you so successfully handled the production of our Cedrus of 1936. We believe it to compare favorably with any book of its size as well as the Cedruses of the past.

The quality and depth of tone in the plates is exceptionally good and even from some of our poorest snaps it seems that the engravings surpass the original glossies in clearness.

Year after year handling of our book and the way it constantly improves certainly is reason enough for our confidence in your company. Keeping within the budget is not an easy job at best but your system is successful.

I especially want to thank you for the fine service that Milt Fitch gave us and his excellent help in every department of the book whether it was laying out an ad, taking a picture, writing copy, or just plain advice.

So on behalf of the staff and for myself personally, I take this opportunity to say "Thanks a lot" and "Best Wishes."

Sincerely,

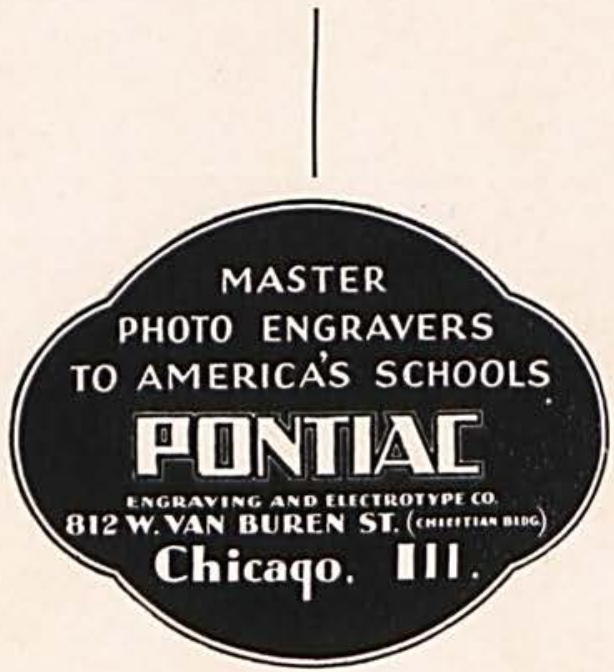


A U T O G R A P H S 


\section{A U T O G R A P H S}




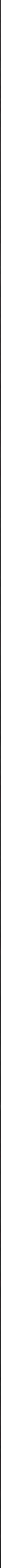




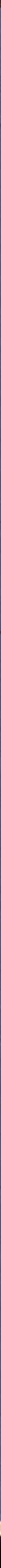




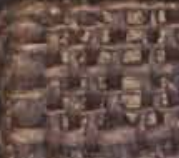

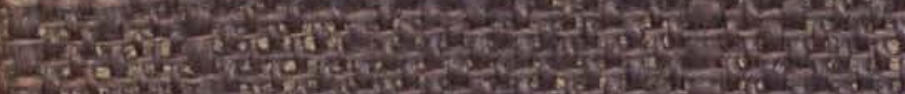

pes.

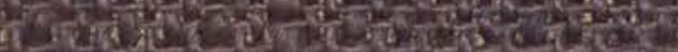

1.7.

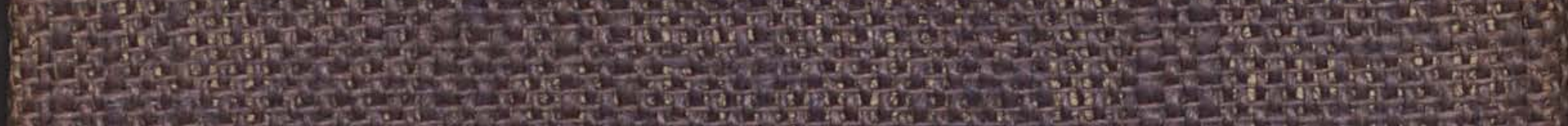

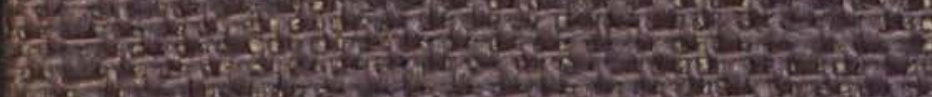

30.

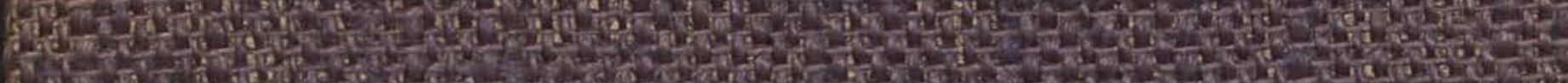

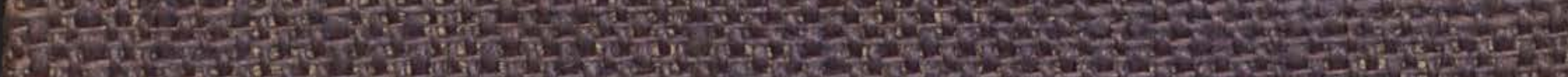

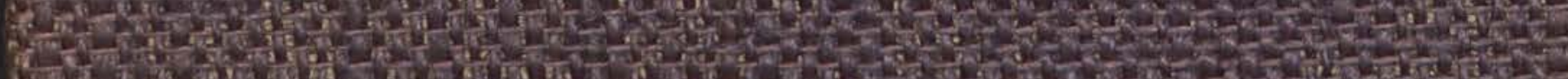

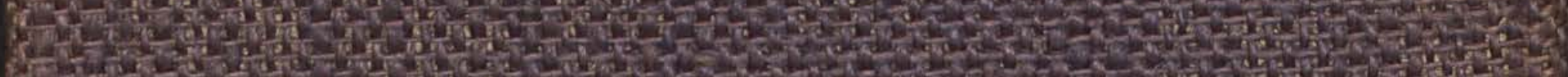
1.5.

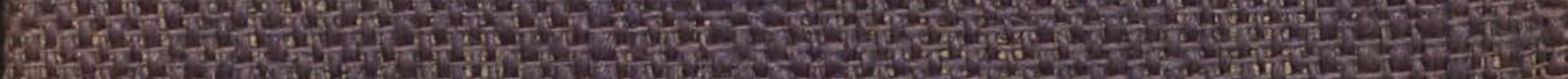
(25.

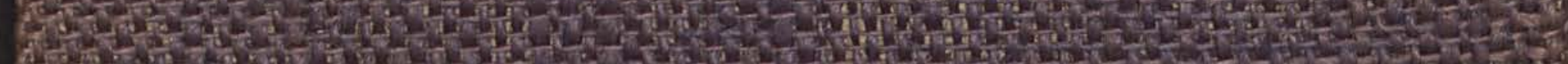
A. Q62.

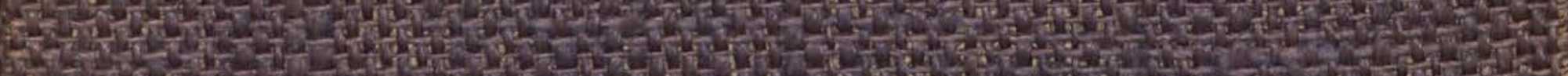

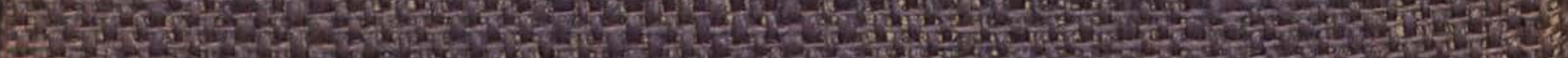
-5.

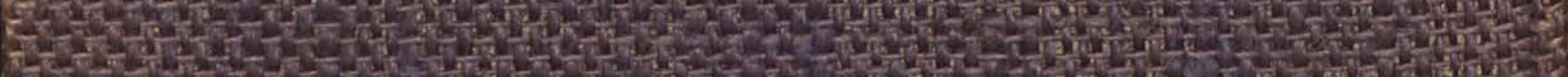

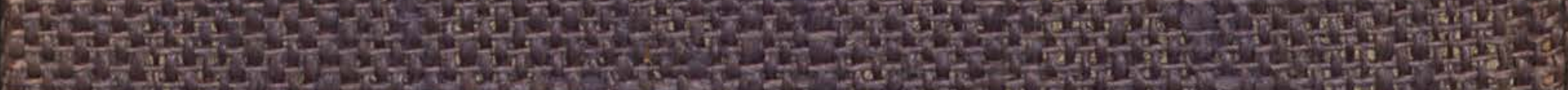

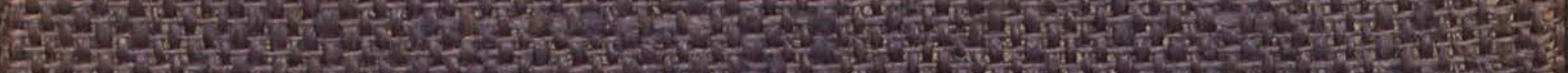

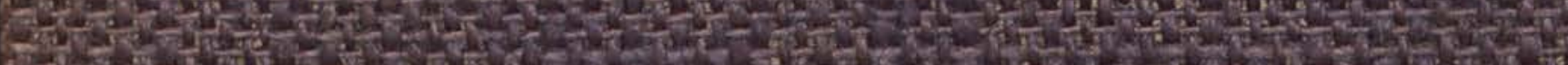

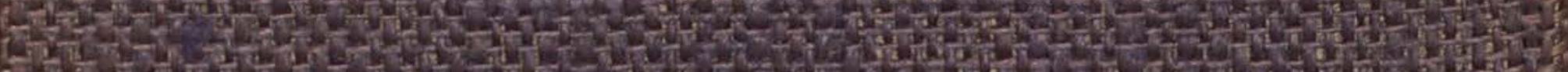

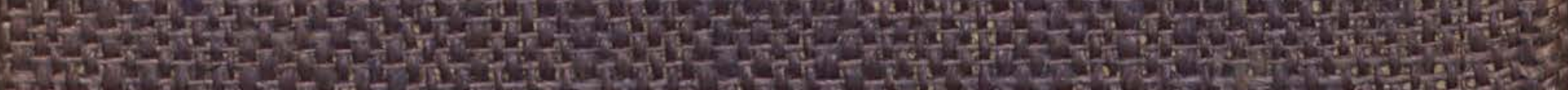

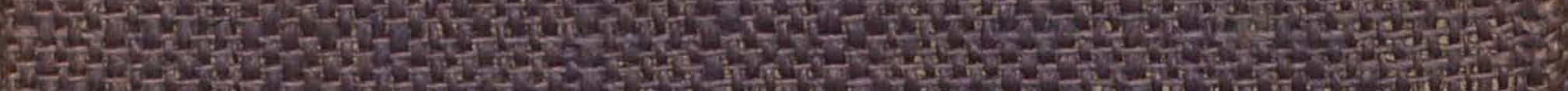
(1) 